\title{
Decentralized centralism: School based management policies and practices at state secondary schools in Mataram, Lombok, Indonesia
}

\section{Bambang Sumintono}

Submitted in fulfilment of the requirements for the degree of Doctor of Philosophy in the School of Education Studies, Faculty of Education at the Victoria University of Wellington, New Zealand June, 2006 


\section{TABLE OF CONTENTS}

Contents ii

List of tables $\quad$ vi

List of figures vii

List of abbreviations and acronyms viii

Abstract $\quad x$

Declaration of originality $\quad$ xiii

Acknowledgements $\quad$ xiv

Chapter 1

INTRODUCTION

1.1 Aim of the study 1

1.2 Background of the study 1

1.3 Research questions 4

1.4. Significance of the study 5

$\begin{array}{ll}1.5 \text { Limitation } & 6\end{array}$

1.6 Key terminology $\quad 6$

$\begin{array}{ll}1.7 \text { Organisation of the thesis } & 7\end{array}$

\section{Chapter 2}

INDONESIA'S EDUCATION: THE CONTEXT OF THE STUDY

2.1 Introduction 9

2.2 Indonesia: basic facts $\quad 9$

2.3 Indonesia’s education: historical perspective 13

2.3.1 Education in Dutch colonial period (c 1840s-1942) 13

2.3.2 Education in Japanese occupation (1942-1945) 16

2.3.3 Education under the Old Order (1945-1965) 18

2.3.4 Education under the New Order (1965-1998) 22

2.3.5 Education in the Reform era (1998 - to present) 33

2.4 Conclusion 46

Chapter 3

REVIEW OF THE LITERATURE

3.1 Introduction 47

3.2 Educational decentralisation framework $\quad 47$

3.2.1 Degree of transfer $\quad 48$

3.2.2 Breath of transfer $\quad 50$

3.2.3 Location of transfer $\quad 50$

3.2.4 Functions transferred $\quad 51$

3.2.5 Power and authority $\quad 53$

3.3 Reason for decentralisation $\quad 55$ 
3.3.1 Efficiency and effectiveness in the delivery of public service 56

3.3.2 The market mechanism $\quad 57$

3.3.3 Equity in the allocation of scarce resources 61

3.3.4 Empowerment of the school community 62

3.3.5 Research on school effectiveness and school improvement 64

3.4 School based management 65

3.4.1 Definitions and resources transferred 66

3.4.2 Site council and SBM models 68

$\begin{array}{ll}\text { 3.4.3 Strategies to make SBM successful } & 72\end{array}$

3.5. Conclusion $\quad 75$

\section{Chapter 4}

\section{METHODOLOGY}

4.1 Introduction $\quad 76$

4.2 Research orientations and methods $\quad 76$

$\begin{array}{ll}4.3 \text { Case study } & 78\end{array}$

$\begin{array}{ll}\text { 4.3.1 Case study location } & 79\end{array}$

$\begin{array}{ll}\text { 4.4 Data collection } & 81\end{array}$

4.4.1 Documentation $\quad 81$

4.4.2 Questionnaire $\quad 82$

4.4.3 Interviews $\quad 86$

4.4.4 Site studies $\quad 89$

$\begin{array}{ll}4.5 \text { Data analysis procedures } & 89\end{array}$

4.5.1 Preparing the data for analysis $\quad 89$

4.5.2 Regulation at national level $\quad 89$

4.5.3 Field data 90

$\begin{array}{ll}4.6 \text { Trustworthiness } & 91\end{array}$

4.7 Ethical Issues $\quad 92$

4.8 Conclusion $\quad 92$

Chapter 5

POLICY AT NATIONAL LEVEL

5.1 Introduction 93

$\begin{array}{ll}5.2 \text { The Decree } & 94\end{array}$

5.2.1 Origin of the decree $\quad 94$

5.2.2 Contents of the decree 97

$\begin{array}{ll}\text { 5.2.3 The decree's appendices } & 102\end{array}$

5.2.4 Other guidelines to the decree 111

5.3 Discussion 113

5.4 Conclusion 115

Chapter 6

PERSPECTIVE AND PRACTICES AT DISTRICT LEVEL

6.1 Introduction 116

6.2 Interviewees’ background 117 
$\begin{array}{ll}\text { 6.3 District level policy } & 118\end{array}$

$\begin{array}{ll}6.4 \text { District education office } & 128\end{array}$

6.5 Education council 136

$\begin{array}{ll}\text { 6.6 Conclusion } & 140\end{array}$

Chapter 7

PERSPECTIVE AND PRACTICES AT SCHOOL LEVEL

7.1 Introduction 141

7.2 School stakeholders’ backgrounds 141

7.2.1 Principals' background 142

7.2.2 Teachers' background 143

7.2.3 School committee members’ background 145

7.2.4 State secondary school general situation in Mataram, Lombok 147

7.3 Information regarding school base management 148

7.4 Views and practices about devolved authority to the school 154

$\begin{array}{ll}\text { 7.4.1 Authority devolved to school } & 155\end{array}$

$\begin{array}{ll}\text { 7.4.2 Financial management authority } & 160\end{array}$

7.4.3 Authority in staff management 167

7.4.4 Authority in curriculum management 174

$\begin{array}{ll}7.5 \text { Parents and community involvement } & 178\end{array}$

$\begin{array}{ll}\text { 7.6 School Committee } & 181\end{array}$

$\begin{array}{ll}\text { 7.7 Effects of SBM policy on the school } & 191\end{array}$

7.8 Attitude toward SBM policy and practices 195

$\begin{array}{ll}7.9 \text { Conclusion } & 196\end{array}$

Chapter 8

CONCLUSIONS

$\begin{array}{ll}8.1 \text { Introduction } & 198\end{array}$

8.2 Overview of research findings 199

$\begin{array}{ll}\text { 8.2.1 The SBM policy } & 199\end{array}$

8.2.2 Devolved authority 201

8.2.3 Community involvement 204

8.3 Discussion and implications 205

8.3.1 The SBM policy at national or district level 205

8.3.2 The district level 210

8.3.3 The school level $\quad 212$

$\begin{array}{ll}8.4 \text { Future agenda } & 214\end{array}$

8.4.1 Future research 216

8.4.2 Final reflection $\quad 217$

$\begin{array}{lr}\text { REFERENCES } & 218\end{array}$ 


\section{APPENDICES}

Appendix 1: Questionnaire

Appendix 2: Interview questions

Appendix 3: Appendices of the Minister of National Education decree number 044/U/2002

Appendix 4: Summary of Mataram district budget year 2004

Appendix 5: Mataram District Budget 2004 for Education and Culture Sector

Appendix 6: School Budget year 2003/2004 of one State Secondary School that participated in site studies.

Appendix 7.1: Teachers' basic information

Appendix 7.2: School Committee Members’ basic information

Appendix 7.3: Sources of SBM information

Appendix 7.4: Authority devolved to school

Appendix 7.5: Schools authority in terms of financial management

Appendix 7.6: Schools authority in terms of staff management

Appendix 7.7: Schools authority in terms of curriculum management

Appendix 7.8: Parents and community involvement in school

Appendix 7.9: Participants' view about School Committee

Appendix 7.10: Benefits and constraints of SBM policy in school

Appendix 7.11: Participants’ attitude toward SBM Policy and Practices 


\section{LIST OF TABLES}

Table $3.1^{1} \quad$ Baselines and Levels of Decentralization and Centralization $\quad 51$

Table 3.2 Location of Decisions by Category of Decision 52

Table 3.3 Initial Strategic Dichotomy Faced in Education Reform 54

Table 4.1 Focus of Questionnaire in the First Section 83

Table 4.2 Focus of Questionnaire in the Second Section 84

Table 4.3 Questionnaire, Section 2, Q8 84

Table 4.4 Questionnaire, Section 2, Q13 84

Table 4.5 Focus of Questionnaire in the Third Section 85

Table 4.6 Distribution of Returned Questionnaire 86

Table 4.7 Interview Sessions $\quad 87$

Table 5.1 Contents of the MoNE decree No. 044/U/2002 98

$\begin{array}{lll}\text { Table 6.1 Interviewees’ profiles } & 118\end{array}$

Table 6.2 Budget Allocation for Education Sector Year 2004

Table 7.1 Principals’ basic information 142

Table 7.2 Participants’ view about SBM policy they got 151

Table 7.3 Participation in SBM training 152

Table 7.4 Participants’ view about SBM policy 192

Table 7.5 Participants' view about role changed because of SBM 194

1 The first number refers to the chapter. 


\section{LIST OF FIGURES}

Figure 2.1 ${ }^{2}$ Indonesian Education System 12

Figure 3.1 The Site Council Role Map in Several Countries 70

Figure 3.2 Backward Mapping from Student Outcomes: an illustration

${ }^{2}$ The first number refers to the chapter. 


\section{LIST OF ABBREVIATIONS AND ACRONYMS}

\begin{tabular}{|c|c|}
\hline BOMM & $\begin{array}{l}\text { Bantuam Operasional Manajemen Mutu (quality } \\
\text { improvement operational assistance) }\end{array}$ \\
\hline BP3 & $\begin{array}{l}\text { Badan Pembantu Penyelenggaraan Pendidikan } \\
\text { (Educational Assistance Body) }\end{array}$ \\
\hline BPPN & $\begin{array}{l}\text { Badan Pertimbangan Pendidikan Nasional (Board of } \\
\text { Consideration on National Education) }\end{array}$ \\
\hline Bappenas & $\begin{array}{l}\text { Badan Perencanaan Pembangunan Nasional (National } \\
\text { Development Planning Agency) }\end{array}$ \\
\hline $\mathrm{DEO}$ & District Education Office (Dinas Pendidikan) \\
\hline $\mathrm{EC}$ & Education Council (Dewan Pendidikan) \\
\hline GBHN & Garis-garis Besar Haluan Negara (State Guidelines) \\
\hline GBPP & $\begin{array}{l}\text { Garis-garis Besar Program Pengajaran (the basic } \\
\text { guide lines for teaching program) }\end{array}$ \\
\hline GDP & Gross Development Product \\
\hline Inpres & Instruksi presiden (presidential instruction) \\
\hline JICA & Japan International Cooperation Agency \\
\hline KBK & $\begin{array}{l}\text { Kurikulum Berbasis Kompetensi (competency based } \\
\text { curriculum) }\end{array}$ \\
\hline MoEC & $\begin{array}{l}\text { Ministry of Education and Culture (Departemen } \\
\text { Pendidikan dan Kebudayaan, or Depdikbud) }\end{array}$ \\
\hline MoHA & $\begin{array}{l}\text { Ministry of Home Affairs (Departemen Dalam Negeri, } \\
\text { or Depdagri) }\end{array}$ \\
\hline MoNE & $\begin{array}{l}\text { Ministry of National Education (Departemen } \\
\text { Pendidikan Nasional or Depdiknas) }\end{array}$ \\
\hline MoRA & $\begin{array}{l}\text { Ministry of Religious Affairs (Departemen Agama or } \\
\text { Depag) }\end{array}$ \\
\hline MPMBS & $\begin{array}{l}\text { Manajemen Peningkatan Mutu Berbasis Sekolah } \\
\text { (School-Based Quality Improvement Management) }\end{array}$ \\
\hline PGRI & $\begin{array}{l}\text { Persatuan Guru Republik Indonesia (Teachers } \\
\text { Association of the Republic Indonesia) }\end{array}$ \\
\hline PKG & $\begin{array}{l}\text { Pemantapan Kerja Guru (strengthening works of } \\
\text { teachers) }\end{array}$ \\
\hline POMG & $\begin{array}{l}\text { Persatuan Orang Tua Murid dan Guru (Parents and } \\
\text { Teachers Association) }\end{array}$ \\
\hline $\mathrm{PP}$ & Peraturan Pemerintah (Government Regulation) \\
\hline
\end{tabular}




\begin{tabular}{|l|l|}
\hline SC & School Committee (Komite Sekolah) \\
\hline SBM & $\begin{array}{l}\text { School Based Management (or MBS, Manajemen } \\
\text { Berbasis Sekolah) }\end{array}$ \\
\hline UNESCO & $\begin{array}{l}\text { United Nations Education, Scientific and Cultural } \\
\text { Organisation }\end{array}$ \\
\hline UNICEF & United Nations Children Fund \\
\hline USAID & United States Agency for International Development \\
\hline UUD 1945 & $\begin{array}{l}\text { Undang-undang Dasar 1945 (the National Basic } \\
\text { Constitution) }\end{array}$ \\
\hline
\end{tabular}

Note: words in italic are Indonesian 


\begin{abstract}
The collapse of Suharto's regime in 1998 brought significant change to Indonesia's public sector. Education at primary and secondary levels, since 1 January 2001, was administered at district level rather than in the previously centralised and bureaucratic manner. At the school level, ideas about school autonomy emerged and became popular. In particular the term 'School Based Management' (SBM) was seen as a panacea, and as a result the central government issued a regulation to implement the practice of SBM.

This study analyses the dynamics of the SBM policy as it was being interpreted and implemented at the secondary school level in Indonesia. It examines SBM in the municipality of Mataram, Lombok, Indonesia. The study was approached in two ways: through document analysis of the Ministry of National Education decree number 044/U/2002 which legalized SBM; and by soliciting and interpreting the perspectives and practices of stakeholders at district and school levels through questionnaires, interviews, school site studies and document analyses. Altogether 83 respondents completed the questionnaires and 24 participated in interviews. Site studies were made to two schools. These approaches produced rich data on issues relating to SBM policy, devolved authority and community involvement.

The study found that the SBM policy as stated in the decree lacked clarity. The decree was hastily introduced and emphasised structural changes at district and school levels without clarifying its underlying rationales or implementation guidelines. The decree did not choose a particular model of SBM. Instead, it imposed a uniform model regardless of school level, size, location, type of community or even the public and private nature of schools.
\end{abstract}


The decree was not followed with any regulations established at the district level regarding SBM. Consequently, institutional capacity at the district level was not developed. Therefore previous paradigm and practices of management continued to remain. Information provided about SBM at the school level was not designed to give much detail. It was left to principals to inform school level stakeholders but the extent to which this happened depended on the principals' discretion and level of knowledge about SBM.

The devolved authority was not clear in the decree. What was suggested in the decree as authority that can be exercised by schools in SBM, was a practice that was already established. Without appropriate regulations at the district level, secondary schools were neither supported nor given flexibility. Mostly, schools practices had not changed with the introduction of the SBM.

The decree did not differentiate between community involvements at the district from the school level. This made it possible for old practices to continue. Hence, Education Council and the School Committees' members were handpicked and shoulder-tapped, based on bureaucrat preferences. Further, at school level, the committees' roles were mainly to legitimize principals' policies, particularly relating to school fees and budget.

In short, a 'new centralism' was seen to be practised by the district government. At the school level the principal's role become much more significant. School Based Management, while fulfilling the regulatory requirements, remains superficial in its impact and has failed to fulfil its original intention of improving the quality of Indonesian education.

The study proposes a number of recommendations for SBM at the Indonesian secondary school level. First, the changing nature of regional 
autonomy in Indonesia makes stipulating a new regulation for SBM at district level sensible. The local regulation should use clear statements, acknowledge diversity, differentiate between governance and management, and recognize community involvement. Second, improving institutional capacity at district and school levels is also necessary and urgent. Enhancing stakeholders' understanding about SBM issues can take various forms. Third, establishing formula funding that is stipulated in the district budget will make previous practices by the school committee unnecessary. Finally, on-going support to schools in terms of SBM, from district and national government is needed and should be programmed to make the policy work and succeed. The study ends with suggestion for further research 


\title{
DECLARATION OF ORIGINALITY
}

\author{
Thesis title: $\quad$ Decentralized centralism: School Based Management \\ Policy and Practices at State Secondary Schools in \\ Mataram, Lombok, Indonesia
}

Candidate’s name: Bambang Sumintono

I declare that this thesis is the result of my own research, that it does not incorporate without acknowledgement any material submitted for a degree or diploma in any university and that it does not contain any material previously published, written or produced by another person except where due reference is made in the text. 


\section{ACKNOWLEDGMENTS}

I would like to thank the New Zealand Agency for International Development (NZAID) for the financial support of this study through the scholarship which enabled me to do my doctoral work. A number of people have also helped in this study. I am very grateful to Dr. Kabini Sanga (principal supervisor) and Dr. Lex McDonald (second supervisor), for their academic contributions, guidance, support and encouragement. My gratitude also goes to Dr. Geraldine McDonald who gave valuable comments about Chapter 2 and also Bapak Abdul Malik who gave suggestions for Chapter 5. Thanks to Dr. John Barrington for proof reading the final manuscript. I would also like to thank all research participants during my fieldwork in Mataram, Lombok; they collaborated fully and provided me with the data that I needed. Thanks to Jay Drew, NZAID Liaison Officer at Victoria International, who has always helped me and my family during our stay in Wellington, New Zealand. Last but not least, I would like to thank Nur, my wife, Fahri and Adrian, my sons, for their love and prayers. 


\section{Chapter 1 \\ INTRODUCTION}

\subsection{Aim of the study}

This thesis is about the implementation of an official decentralisation policy in education called school based management (SBM), popularly known in Indonesia as manajemen berbasis sekolah (MBS). The location of the study is Mataram municipality, a capital district of West Nusa Tenggara province in Indonesia. The study critically analysed the regulation that established the SBM policy and examined stakeholders' perceptions and responses to the policy at district and public secondary school levels. In particular, the study sought to identify and evaluate constraints and the adequacy of resources related to policy implementation, in order to inform policy makers at regional level about school governance issues. The study is important because since 2001, authority in education had been transferred to the district level, based on Law 22/1999 (later reviewed by Law 32/2004).

In the following sections, I discuss the background to the study, outline the research questions, and provide an overview of the organisation of the thesis.

\subsection{Background of the study}

Indonesia’s schooling system was introduced by the Dutch as the colonial power and was managed in a centralised and bureaucratic manner. Three years of Japanese occupation during the World War II also maintained a centralised system. It is easy to understand how, from a colonial viewpoint, central control was necessary and advantageous. However, even after Indonesia’s independence 
in 1945, right up to 2000, a centralized system of administration continued to be relied upon to manage the public education sector.

The Asian financial crisis which started in June 1997 had a different impact in Indonesia, compared to other Asian countries. University students demonstrated around the country and public pressure led to the replacement of President Suharto, who had been in power for 32 years, in May 1998. It was form this point that the reform era in Indonesian politics begun.

Within a year, the Indonesian parliament passed two new laws relating to regional autonomy: Law 22/1999 which involved devolution of political authority, and law 25/1999 which was about fiscal balance. Aspinall and Fealy (2003, p. 3) observed that these developments produced "one of the most radical decentralisation programs attempted anywhere in the world”. This is because within two years, significant authority was to be devolved to more than 360 district governments from the previously highly centralised control from the capital, Jakarta. The introduction of new regulations regarding local government autonomy, which became effective in January 2001, also meant that policy decisions in the education sector (i.e., K-12) could now largely be made by the government at the district (Indonesian: kabupaten/kota) levels.

Five months after Suharto stepped down, the World Bank released a report entitled Education in Indonesia: from crisis to recovery. It noted that the state of Indonesia's education system was very poor, reflected in indicators such as a high drop out rate, a low school participation rate, and low student achievement. One of the suggestions in the report was to improve education through a decentralisation policy. As a consequence, the National Development Planning Agency of the Republic of Indonesia (Bappenas) together with Ministry of National Education 
(MoNE), with funding by the World Bank, established several task forces to find ways to improve Indonesia’s education (Jalal \& Musthafa, 2001).

In July 2000, at a national seminar on education reform in the context of regional autonomy, the reports of these task forces were tabled, several ideas about educational change were highlighted (Kompas, 2000a). In particular, ideas about school governance at primary and secondary level, popularized as school based management (SBM), became a popular topic at the seminar. The proponents of SBM argued that to improve education during the autonomy era, Indonesia must adopt democratic, transparent, efficient by its citizens, and this could be achieved by adopting SBM as the model for administering schools. At the fourth Convention on Education at the national level, held in Jakarta in September 2000, SBM was further promoted and it became the sole choice for restructuring Indonesian schools. It was believed that SBM would improve the quality of education (Kompas, 2000f). Newspaper articles about SBM became widespread and school stakeholders such as teachers, parents, and community members hoped for an early implementation of the approach.

The official move to SBM for Indonesian schools was not seen, however, until after the release of a Minister of National Education decree number 044/U/2002, in April 2002, concerning school committees and education councils. The decree stated that each school had to establish a School Committee (SC), which is the Indonesian name for site council, consisting of the principal, representatives of parents, community members, and students as well as teachers. The decree also stipulated the various roles of the committee in its governing function. At the district level, an Educational Council (EC) had to be established with members and roles which were quite similar to a school committee, as stated 
in the decree. The decree was also strengthened by legislation related to the new national education system (Law No. 20 of 2003), which was passed by the parliament in June 2003.

These education reforms were being introduced while I was teaching at a state secondary school in rural Indonesia. Like many other Indonesian teachers, I felt the idea of SBM seemed appropriate to the realities of our situation. My initial response to the new educational decrees was one of excitement. As a teacher I was interested in the changes that were proposed. In particular, I was interested in the shift of power from central government to district and then to school level jurisdictions. What was actually proposed? What was the rationale? What were the envisaged implications for schools? To what extent were districts and schools clear about the reforms and their implications? These and many more questions were asked by teachers such as myself. The questions, represented the considerable interest of the teachers and educators in Indonesia. In the relevance of the reforms, as a teacher, the SBM seemed to offer certain promises and possibilities, including that of improving educational quality. My interest in this reform agenda and subsequently this study, was to investigate the extent to which these promises were achieved.

\subsection{Research questions}

This study investigates the policy that relates to school based management and its practices as they operate in Indonesian state secondary schools. The study is intended to reveal the constraints and opportunities arising from the introduction of the SBM to the Indonesia education system particularly with reference to school governance at secondary school. The research questions of this study are: 
Related to relevant regulations and issues at the national level

1. Are the policy regulations related to the SBM in Indonesia reliable and applicable?

2. What is Indonesia's model of SBM: its characteristics, goals and the reasons given by the central office for the adoption of the model?

Related to SBM implementation at district level

3. In what ways do district level stakeholders respond to education decentralisation, particularly to the SBM policy?

4. What relationships developed between stakeholders in relation to the newly created education board, and what tensions, if any, arose?

Related to the realities at state secondary school level

5. To what extent do principals, teachers and school committee members understand SBM and what is their attitude to it?

6. To what extent do school committees play a role in school governance?

7. What are the current constraints limiting successful implementation of the SBM at the school level?

\subsection{Significance of the study}

The value of the study is in its contribution to greater understanding of Indonesia's education during the autonomy era. As well, the study will increase our knowledge about the early stages of implementation of SBM in a developing country. The study is of value to administrators, principals, teachers and parents who are concerned with the introduction and operation of SBM in Indonesia. More broadly, the study adds to the global discussion on decentralisation, education reform and SBM.

\subsection{Limitation}

A general limitation that may be associated with research of this kind is in relation to generalisability of its findings. That is, the particular nature of educational decentralisation and SBM in Indonesia probably cannot be generalised 
to other countries' contexts. Another limitation is that the nature of Indonesia's educational decentralisation and SBM, particularly in Mataram, may reflect political considerations more than or equal to representative sampling, even of the local jurisdiction in Indonesian.

\subsection{Key terminology}

Some key terminologies used extensively in this thesis include:

- School Base Management: a model of administering schools in a public school system where there is significant devolution of authority, at least in personnel, budget and curriculum.

- Regional autonomy: based on Law 22/1999, from 1 January 2001 district governments across Indonesia were given authority to manage public sectors from the previously centralised regime.

- Education Council: a council at the district level, with particular roles and functions as stipulated in the MoNE decree, allowing for community involvement.

- School Committee: The Indonesian name for the committee at the school level, replacing the $\mathrm{BP} 3$, will roles and functions quite similar to the council.

\subsection{Organisation of the thesis}

Subsequent chapters cover: (2) the Indonesian education context, (3) literature review, (4) methodology, (5-7) data analysis and interpretation, and (8) general discussion, conclusions and implications.

Chapter 2 reviews schooling in Indonesia from the colonial era to current developments during the reform era, and explores historical and political factors that affected education. Chapter 3 discusses the international literature on educational decentralisation, particularly on school based management, to provide 
some general theoretical framework to guide the research process. Chapter 4 covers the research orientation, the data collection and analysis procedures used in this study.

Chapters 5-7 analyse and interpret the data. Chapter 5 focuses on document analysis about school based management policy, particularly the MoNE decree number 044/U/2002 regarding educational council and school committee. The analysis examines the origin of the decree, its contents and appendices and related official documents. Chapter 6 examines stakeholders at the district level, and documents their understandings, attitudes and opinions about school based management; and the Education Council. Chapter 7 discussed the experiences of school based management at the school level, including the knowledge and beliefs, attitudes and opinions of the principals, teachers and school committee members in Mataram public secondary schools.

Finally, Chapter 8 summarises the major findings analysed in chapters 4-6 and then discusses them in relation to the school governance reform agenda in Indonesian state secondary schools. The chapter concludes with recommendations for developing school based management at the national, district, and school levels, and also for future researchers. 


\section{Chapter 2}

\section{INDONESIA'S EDUCATION: THE CONTEXT OF THE STUDY}

\subsection{Introduction}

This chapter reviews the historical and political developments of education in Indonesia from the colonial era to the present day, including the policies and practices of the past which were adapted by past regimes, and the latest developments in school governance.

Education, as part of the public sector, cannot be separated from the state system and therefore the political culture will determine not only the process of policy development but also the content of policies in education (Wirt, Mitchell \& Marshall, 1985). In the case of Indonesia, as will be shown, political power determines nearly everything in education. Before reviewing the practices that shaped the Indonesian education system from the time of Dutch rule, I will provide some basic facts about the country.

\subsection{Indonesia: basic facts}

Indonesia is a new country in the Southeast Asia region which gained its independence in 1945. It had a long history of colonization by the Dutch, starting in the Maluku islands in the seventeenth century, then gradually moving to other islands, and finally to Aceh which was completely occupied only in the early $20^{\text {th }}$ century (Ricklefs, 2001). During World War II, the Japanese occupied the East Indies, which was the name given by the Dutch, and held the territory for three years from 1942. After independence, the history of Indonesia can be 
divided into three periods, the Old Order under the leadership of Soekarno (1945-1965), the New Order when Soeharto was the president (1966-1998) and the Reform Era (from 1998 to the present day).

Nowadays, Indonesia is important within the region in terms of size, strategic location and natural resources. It is the world's fourth most populous country (230 million people in 2004) and the third largest democracy whose people can speak one national language, Bahasa Indonesia (a modified form of Malay). Most Indonesian people are Muslims (88\%) but there are also other religions, such as Christianity (5\%), Catholic (3\%), Hinduism (2\%), Buddhism (1\%) and others (1\%). The majority of Indonesian people live in Java (64\%) where there are two major ethnic groups: the Javanese (over 70 million people) who live mainly in Central and East Java, and the Sundanese (more than 40 million) who live in West Java (Clark et al., 1998). However, there are also more than 580 other ethnic groups within the nation who speak local languages and exhibit a diverse range of cultures. The members of these groups range from several hundreds to millions.

Indonesia is the world's largest archipelago with more than 17,500 islands bridging two continents, Asia and Australia. The geographical location of Indonesia is on the equator extending from the Indian to the Pacific Ocean and with a length of 5,110 kilometres (3,997 miles). The total area of Indonesia is nearly 2 million square kilometres, $81 \%$ of it is sea and the rest land. It has a diverse geography, ranging from swamp, tropical rain forest, to high mountain tops covered with ice. For the purposes of administration, Indonesia is divided into 33 provinces and more than 400 districts. 
The tropical climate and active volcanoes have made Indonesian soil fertile, making it easy for plants to grow. Indonesia also has mineral resources such as oil, natural gas, gold, and copper, which provide offer economic opportunity. However, most Indonesians are poor. The GDP per capita in 2003 was \$ 940 a year and nearly 40 million of the workforce is underemployed or unemployed.

The Indonesian education system is based on 6-3-3-4 school years. In other words, there are six years of primary, three years of junior secondary, three years of senior secondary and four years of college education. There is an Islamic schooling system, secular schooling and out-of-school education (Figure 2.1 shows the structure). More than 40 million students are enrolled in school, $61 \%$ percent of them in primary schools, $18 \%$ in junior secondary, $11 \%$ in senior secondary, and 6\% in tertiary education (Purwadi \& Muljoatmodjo, 2000: p. 50). 


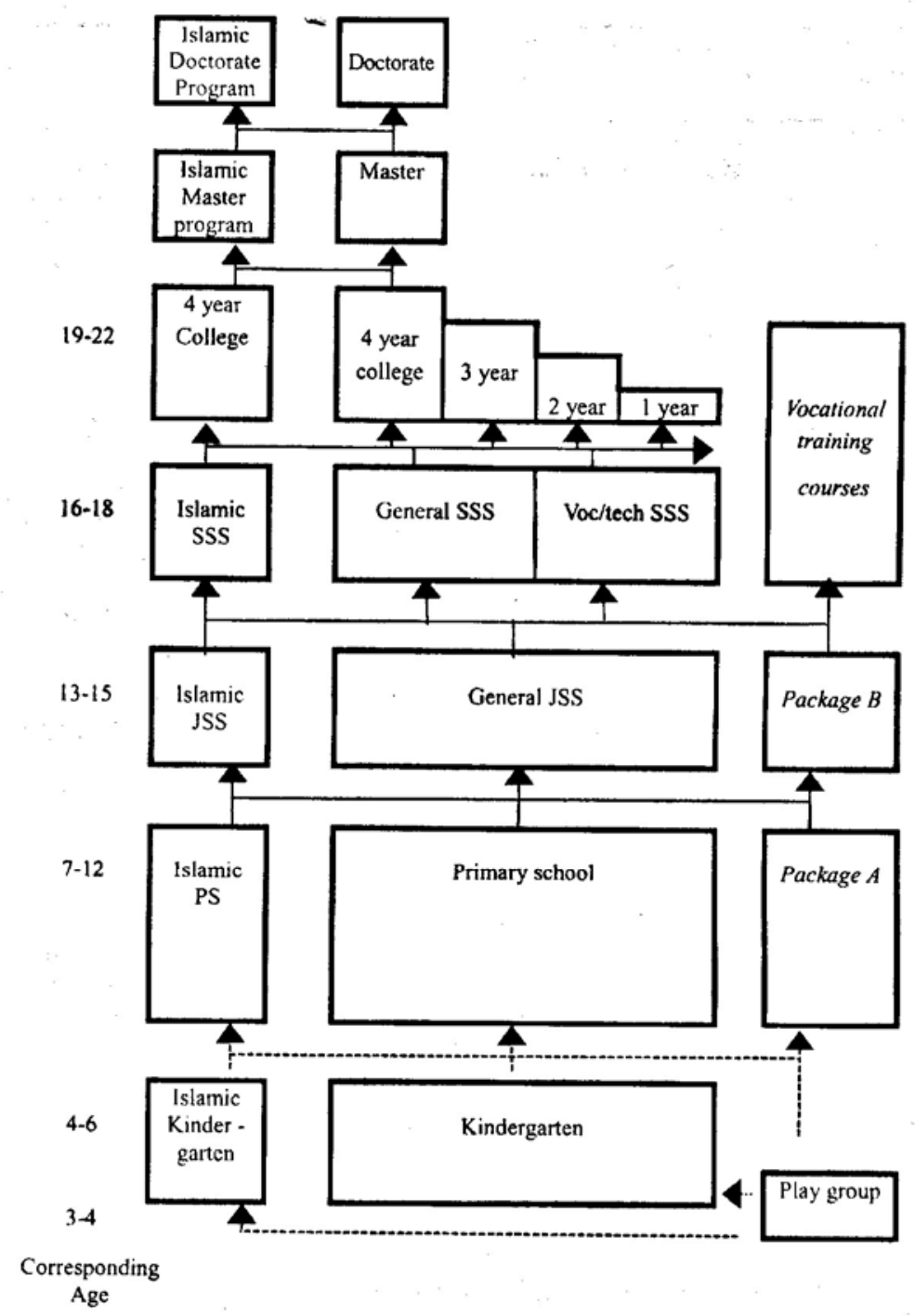

Figure 2.1. Indonesian Education System

Note: paths indicated by --- $\rightarrow$ are not prerequisites for access to a higher level of education.

(source: Purwadi and Muljoatmodjo, 2000: p. 89) 


\subsection{Indonesia's education: historical perspective}

Looking at Indonesia's education from an historical perspective helps to explain some enduring features. Some issues, problems and weaknesses from the past still survive and their lasting nature makes them difficult to solve. The reasons are not always educational, but have their origins in political struggles. This background will provide a context and reasons for the complexities of educational policy.

\subsubsection{Education in the Dutch colonial period (c 1840s - 1942)}

According to Clark et al. (1998), prior to colonisation there was no formal schooling in Indonesia. Indonesian families and communities educated their young mainly through informal apprenticeships. There was also some informal education based on several religions for the purpose of spreading the beliefs of Hinduism, Buddhism and then Islam through the pesantren (Islamic boarding school). Christianity arrived mainly with colonial missionaries (Jalal \& Musthafa, 2001). Then the Dutch colonial government established formal schools for European and Eurasian (European-Indonesian heritage) children and descendants of local chiefs and princes (Clark et al., 1998).

Formal education for the masses started in 1848 when the Dutch colonial government realised that to maximise the harvesting of Indonesia natural resources it would be cheaper to employ educated native people rather than Dutch workers (Lee, 1995). Therefore from that time, enrolment numbers rose and formal schooling became more widespread. In 1901, this educational development was strengthened by what was called the ethical policy (ethische politiek) developed by the Netherlands government (van der Veur, 1969; Lee, 
1995). The policy stated that the Dutch colonial government had a responsibility to improve the social and economic situation of the indigenous population. According to Lee (1995) the main reason for this policy was to counter a PanIslamic movement which was, at the time, gaining ground. Fearing this development the Dutch colonial government, needed to (Lee, 1995, p. 5):

...create a new Indonesian elite, Dutch educated and secular in outlook, whose leadership would help lead to a close cultural understanding of the two nations.

The effect of this policy meant that the number of local people who participated in education rose astronomically (Clark et al., 1998; van der Veur, 1969) and the school system became more complicated (Djajadiningrat, n.d.).

Colonial regimes design education systems according to the needs of the rulers, and not necessarily to meet the needs of the colonised, and the situation was no different here. The content of formal schooling was organised by the Dutch for purposes of control, with the colonial government administering education in a centralised and bureaucratic manner in line with colonial purposes.

Djajadiningrat (n.d.) states that two kinds of school systems were developed: oriental education and occidental education. Oriental education was mainly for native people most of them would spend three years in a village primary school funded by native princes, and the local language would be the language of instruction. Only students who came from noble families stayed for two more years of primary schooling. The occidental education system ranged from schools for the descendants of Europeans to schools for an "eastern foreigners” group (some Arabs and Indians but mostly Chinese) and in them the Dutch language was used for teaching. Later, native people who came from 
advantaged backgrounds could enrol in an occidental primary school. The different education systems reflected the colonial government's discriminatory policy, which placed European groups at the top, eastern foreigners in the middle and native Indonesians at the bottom of the structure of colonial society. In addition Clark et al., (1998) found that as the levels of education became higher, the number of native people who participated became smaller.

The secondary school in the oriental education sector ended after three years of lower secondary schooling in the MULO (Meet Uitgebreid Lager Onderwijs), while the occidental education system continued to a higher level. There were two types of secondary education: a general secondary school and a vocational secondary school. In all these schools the language for teaching and communication was Dutch. According to Djajadiningrat (n.d.) general secondary schooling existed in three forms: Lyceum, HBS and AMS. The Lyceum was a six year general secondary school exclusively for European students, and its curriculum prepared graduates for higher education. The HBS (Hogere Burgelijjke School or Citizens High School) was similar to the Lyceum but all groups of students could enrol. The AMS (Algemene Middlebare School or General Secondary School) provided three years of study for students who passed a lower secondary school, such as from the MULO, which all groups of students could enter. All general secondary school graduates could continue to higher education, particularly in the Netherlands, and there they could become lawyers, doctors or engineers. For students who took vocational secondary schools there were several types available. These trained students to become government officials, primary school teachers and agricultural workers. 
In 1912 Muhammadiyah, originally a social Islamic organisation, started offering education outside the colonial system. In 1922, Ki Hadjar Dewantoro established a network of schools called Taman Siswa (garden of pupils). Both the Taman Siswa and Muhammadiyah developed modern educational methods as an alternative system for the indigenous people. They supplied primary and secondary schooling and teacher training (Jalal \& Musthafa, 2001). The curriculum content of these schools was drawn from both European schools and Indonesian culture.

One of the results of the Dutch formal education system was the emergence of indigenous political leaders who developed ideas about independence which went beyond what the Dutch intended. The idea of Indonesia as a unified country leading to nationhood became inevitable. In 1928 the representatives of almost every ethnic group gathered for the first conference of Indonesian Youth, and this became a milestone in the development of nationalism. The motto “one country, one people, one language” became widely accepted (Clark et al., 1998).

\subsubsection{Education under Japanese Occupation (1942-1945)}

In March 1942, in the middle of World War II, Japanese military forces invaded Indonesia and rapidly occupied the entire Dutch colonial territory, replacing the Dutch as the colonial government until the end of the war in August 1945. The ending of the war brought hope to the Indonesian people that independence might now be achieved (Jalal \& Musthafa, 2001).

During the Japanese occupation, the elitist and complicated Dutch colonial education system was abolished. The Japanese established a 
standardized school system: six years primary, three years lower secondary and three years upper secondary (Lee, 1995). All children could enrol without discrimination by race or family background. The Japanese also introduced different kinds of lower secondary schools consisting of academic, vocational and technical schools. The three year upper secondary schools were quite similar to the Dutch system, but the Japanese introduced Bahasa Indonesia (Indonesian language) at all levels of education as the language of instruction. However, the Japanese language was also a required subject. Indonesian also became the official language of the administration. Although Bahasa Indonesia had been declared in the youth pledge as the unofficial national language in 1928, it was Japanese rule which introduced a communal language which changed the nature of Indonesian education (Lee, 1995; Jalal \& Musthafa, 2001)

There were similarities between both the Dutch and the Japanese education systems in terms of a centralised administration and the aims of formal education. To assist their occupation, the Japanese established top-down control from a central office in Jakarta. All people involved in the education system had to be trained in what was called Kemakmuran Bersama Asia Timur Raya (Greater East Asia Co-prosperity Sphere), intended to promote Japan’s interests during World War II (Poerbakawatja, 1970). As a result, students at all levels of education were trained in physical and military skills. Moreover, school activities involved largely indoctrination rather than academic subject matter, and freedom of speech and thinking were forbidden (Poerbakawatja, 1970; Lee, 1995). 


\subsubsection{Education under the Old Order (1945-1965)}

Indonesia as an independent nation-state was created on 17 August 1945 and proclaimed by Soekarno and Hatta, both Dutch educated, and elected as president and vice-president of Indonesia respectively. Soekarno governed the new republic for a twenty year period, and this has been named the Old Order. However, the Dutch government tried to reclaim Indonesia as its colony after the departure of the Japanese. This led to confrontation with the Dutch and to four years of sporadic warfare called the Indonesian Revolution, which was fought to defend the new republic (Ricklefs, 2001).

From the beginning of its independence, Indonesia's national leaders understood the importance of education to maintain and strengthen the unity of the new nation-state. Shortly after independence was proclaimed, Dewantoro as education minister revoked all the regulations established by the Japanese and drew up guidelines which consisted mostly of provisions with a political rather than an education purpose (Lee, 1995). However during the Revolution some parts of Indonesia remained under Dutch control and there the schools, following the previous colonial education system, were opened as a sign of Dutch sovereignty. In other parts of the country, where the new republic ruled, schooling was supported by the community and individuals who could read and write volunteered as teachers (Poerbakawatja, 1970; Clark et. al., 1998). However during the revolution, many school age students preferred to join the fighting (Poerbakawatja, 1970; Lee, 1995).

In 1950 the Indonesian government drew up the first education law, Law 4/1950. Under it, the state ideology, Pancasila, became the fundamental basis of Indonesian education (article 4). Pancasila consisted of five principles: Believe 
in one and only one God; A just and civilized humanity; The unity of Indonesia; Democracy guided by the inner wisdom of deliberations of representatives; and Social justice for all Indonesian people. Bahasa Indonesia became the language of instruction (article 5). The law also incorporated egalitarian principles such as a compulsory primary school system funded by the state. The school system was similar to the Japanese system in that it was standardized and governed from the centre by the Ministry of Education and Culture (MoEC) in Jakarta (Poerbakawatja, 1970; Lee, 1995). However the law did not regulate Islamic schools, which were already established and which also provided schooling from primary to secondary levels. Most of the curriculum content of the Islamic schools which were controlled by the Ministry of Religious Affairs, was similar to that of the secular schools.

In the 1950s, with signs of peace, there was a marked development of formal education and a substantial rise in school enrolments. The primary school population rose to 11 million students (Jalal \& Musthafa, 2001) whereas in both previous colonial eras (Dutch and Japanese) only about 2.5 million students participated (Poerbakawatja, 1970). To administer the increasing number of students and because of criticism that education was too centralized, the government drew up a decentralisation plan with a Peraturan Pemerintah (Government Regulation) or PP 65/1951. This stated that primary schooling was to be devolved to provincial governments. The Ministry of Home Affairs was to supply men, money and materials (3M) and the MoEC was to supply technical guidance for the curriculum, textbooks, teaching methods, assessment and school supervision (Lee, 1995, p. 78). Later, the administration of junior and senior secondary schools was transferred to the MoEC provincial office (Kantor 
Wilayah). The conduct of schooling then involved three ministries, the MoHA (primary schools), the MoEC (junior and senior secondary schools) and the MoRA (Islamic schools).

The teacher's union or PGRI (Persatuan Guru Republik Indonesia, Teachers Association of the Republic of Indonesia) opposed the devolution of the regulations to the provincial level and demanded that responsibility be returned to the MoEC. The reason, according to Lee (1995, p. 78), was because the provincial governments

...were staffed by officials with little teaching experience or appreciation of educational matters, and might not therefore understand the real needs of school and the teacher.

Insufficient funds for school operational costs, and the salary delays later experienced by the teachers, provided a demonstration of the neglect and incompetence of local staff (Lee, 1995).

The rapid development of education needed to be funded but the new republic did not have sufficient funds. One solution was to depend on community support and require parents to pay a school tuition fee. The MoEC released a decree number 58438/Kab concerning Panitia Pembantu Pemeliharaan Sekolah (committee for school maintenance and assistance) to make that article 28 in Law 4/1950 which stipulated community support to the school, to be more operational and detailed (Poerbakawatja, 1970). Later, the name of this new committee was changed to one which matched that of parentteacher-organisations in the United States. Translated into Indonesian it became Persatuan Orang Tua Murid dan Guru (POMG). The decree stated that the POMG was the only body which could collect money from parents. Principals and teachers were not to become officially involved. However, Poerbakawatja 
(1970) states that the intention not to involve the principal was difficult to maintain, and the POMG became the principals' instrument. In addition, in order to make the work of the POMG easier, the role of principals was widened and the principal became the person who in practice collected money from parents. This sometimes occurred regardless of parents' economic background (Poerbakawatja, 1970). Reports show that money gathered from parents by the POMG was "paying a major share of the upkeep of schools including the allowance of teachers” (Lee, 1995, p. 171).

The first general election in 1955 resulted in a parliament which engaged in a constitutional dispute which led to a crisis in 1957. Backed by the military, President Soekarno released a decree to abolish parliament in July 1959 and restored the old constitution (Ricklefs, 2001). A month later the president declared Manipol or Manifesto Politik (Political Manifesto) which called for:

revival of the spirit of the Revolution, for social justice and for 'retooling' of the institutions and organisations of the nation in the name of ongoing revolution.

Feith (1963) writes that the impact of Manipol was felt across Indonesia and especially affected civil servants including teachers. Indoctrination became the major 'retooling' programme supported by the army. The performance of state employees was assessed by their wearing a uniform, taking part in a flag ceremony, and following their superiors without objection.

The 'retooling' program systematically changed the direction of education to political purposes and restricted freedom of thinking (Tilaar, 2000). The policy was managed by Prijono, the education minister, and this led to demoralization within the administration of the MoEC (Lee, 1995). One of the 
legacies from the Old Order era, still practised today is the flag raising ceremony. Jazadi (2003, p. 36-37) describes the ceremony:

This takes place for about an hour or so in the morning (lesson hours 1 and 2), every Monday, at the beginning of the working week The ceremony takes place in the school yard (all schools -the public ones certainly have- are supposed to have one) where students, teachers, principal and all other staff will gather in a military fashion. The principal or an appointed teacher is the inspector of ceremony who addresses the audience and leads the moment of silence to pray for the national heroes. Classes are appointed in turn to be ceremony executives, consisting of one ceremony commander, class or year leaders, readers of the nation's text (the "1945 Basic Constitution", the "1928 Youth Pledge" and "Pancasila", the State Ideology). The last two are followed by all participants in chorus. Then a song leader leads the singing of the national anthem and one or two national struggle songs, as well as song dedicated to teachers called "Teacher Hymn”. Finally, a prayer reader prays for God's blessing for all the audience and the nation. The ceremony is made so sacred that, most particularly during the singing of the national anthem and when flag is raised, everyone has to focus on the flag and salute it. Anyone who comes late or accidentally passes by has to stop and join the ceremony. Failing to do so may be considered ideologically subversive and so endangers the perpetrator.

Another event of this time was the continuous conflict with the Dutch over West Papua. The Dutch lecturers and teachers who had stayed on after independence were sent back home. The availability of international aid, mostly from the US, allowed many Indonesian students to study overseas. When they returned they become the powerful architects of Indonesia's future.

\subsubsection{Education under the New Order (1966-1998)}

A failed coup by the Communist Party led to a Javanese army general gaining power. General Soeharto become president in 1966 and ruled for 32 years. This period has come to be called the New Order. The new government inherited conditions of turmoil such as triple digit inflation, political instability and even the likelihood of civil war. To heal the nation, the New Order government produced a five year development plan called Repelita (rencana 
pembangunan lima tahun or five years development plans). Repelita was managed by a number of economists, planners and engineers who were US educated and "who have emphasized rationality (e.g. in trade and monetary policy), efficiency and economic development (growth)” (Nielsen, 2003, p. 404) as a way of achieving economic stability. Supported by foreign loans and investment from Western countries, and following the 1973 oil boom, Indonesia's economic development grew rapidly. From the beginning of the implementation of the Repelita in the late 1960s until the late 1980s, Indonesia's economic growth was at the rate of approximately 8\% per year (Jalal \& Musthopa, 2001).

However, maintaining political stability to assure economic growth meant that the government had to rely on security measures in many situations. The emphasis on security was controlled centrally from Jakarta by the military and the bureaucracy and affected every state agency at all levels of government. The Indonesian armed forces (ABRI) adopted a special policy called $d w i$ fungsi (dual functions). This meant that the role of the armed forces extended beyond defence to development. In practice, military personnel were appointed to civilian positions at all levels of government and parliament. Active military men became ministers, governors, directors-general in every ministry, and chief executives of state-owned companies and heads of district governments. Having civilian positions made it easy for the military to maintain stability in civil agencies. The state bureaucracy, consisting of civil servants, became part of the political machinery rather than rendering service to the community. In general elections state employees were expected to be loyal to the ruling party, which was Golkar, which had to win at all cost. 
This kind of situation produced a "bureaucratic authoritarian state" (Nielsen, 2003) and the only choice for government was heavy intervention. Countries such as Indonesia, experiencing late industrialization, often adopt this kind of government in order to maintain stability. The national education system suffered once more and the change from the Old Order was that as a tool of control it was used in a more sophisticated way. Nielsen (2003, p. 407-408) concludes that during the New Order the main characteristics in Indonesian education were:

- an emphasis on rapid growth and quantitative expansion as indicators of quality improvement;

- $\quad$ excessive power and control at the central office level;

- a slant towards national security issues and unquestioning loyalty to the state ideology

- excessive reliance on external resources (funds, technology and expertise); and

- the promotion of interagency fragmentation and competition

As a result, the poor performance of education was widespread, and appeared at every level. There are several issues based on Nielsen's first three points which I would like to discuss particularly with reference to state secondary schools.

\section{Emphasis on rapid growth and quantitative expansion}

During the three decades of the New Order, the financial position changed. The availability of money from exporting oil and gas made it possible to build thousands of schools. Duflo (2004) notes that during 1974-1978 more than 61 thousand primary schools were built based on the Inpres policy (instruksi presiden, presidential instruction) which stated that there should be one primary school in every village. According to Leigh (1999) expenditure on these primary schools alone drained one third of the Inpres budget. As a result primary 
schooling enrolments rose by 37\% (to become 95\%) in the 25 year period from 1969. Participation rates in higher schooling also rose significantly to $58 \%$ for junior secondary schooling and $35 \%$ for secondary school (Purwadi \& Muljoatmodjo, 2000).

School expansion was followed by the recruitment of new teachers at all levels of schooling. They were appointed as government employees. By the 1990s the total number of teachers reached nearly 2 million. There was continuing success in terms of quantitative improvement relating to teachers. Nielsen (2003, p. 404) reports indicators such as: "the numbers of years of preservice training, the number of teachers upgraded, the numbers of teacher study groups formed”. At the secondary school level, teacher professional development, a policy initiative by central government formed what was called the Pemantapan Kerja Guru (PKG, or strengthening the work of teachers). Thair and Treagust (2003: p 202) write that:

by any measure, the PKG project was an extremely ambitious undertaking, establishing an extensive network of teachers-trainers and overcoming the logistical obstacles associated with operating in a developing country so geographically and culturally diverse

However, this rapid growth and quantitative expansion was not necessarily relevant to quality. What was called a school, according to Leigh, (1999, p. 38) was "basically a cement floor with brick wall, shuttered windows and a tiled roof", and classrooms condition "tend to be very basic, with old furniture, drab walls, little lighting, poor air circulation and only minimal resources” (White, 1997, p. 91). More than half of the school buildings erected by the Inpres programme were poorly constructed and after twenty years were damaged and nearly half had even collapsed (Kompas, 2004). 
In addition to teacher quality, other problems which arose were the relevance of teachers' academic background to the subjects they taught, uneven distribution between urban and rural area, and inadequate salaries. Many projects dedicated to enhancing teachers' quality did not work because they were irrelevant to the need, tutors were inadequately and inappropriately trained, and under-funding made the effort unsustainable (Nielsen, 2003; Thair and Treagust, 2003).

Another problematic arose with the school final examination (years 6, 9 and 12). According to Umar (2004), before 1969 these school examinations were conducted centrally in a strict manner and with high standards which resulted in few students passing. The US-trained educational bureaucrats changed this system. They introduced a final examination in which decisions about which students should pass was handed over to the school. It was argued that only the teachers knew the quality of their students’ performance. The immediate result of this policy was that the percentage of students who passed rose to nearly $100 \%$ in every school. This occurred in every part of the country because teachers and principals used the opportunity, but they were also pressed by their superiors in the district and provincial education office to follow an "unwritten policy" which was to pass any students regardless of their academic achievement (Bintoro, 2004, personal communication). To illustrate, at secondary level, studies by Tilaar (1992) and Suryadi (1998) showed that, except for civics and Indonesian subjects, students' results were far below standard, which was 6 for a range of 0 to 10 . However, regardless of these poor results, nationally an average of $98 \%$ of secondary school students passed the exam, and in some provinces the pass rate even reached $100 \%$. This was the practice followed for 30 years in order to 
demonstrate that the education system had succeeded in terms of quantitative achievements. In fact it has had a bad impact on Indonesia's younger generation who, according to Tilaar (1992, p.140), have been mis-educated by the system.

\section{Excessive Bureaucratic Centralization}

Schooling is a significant part of the public sector managed by the state in most countries. Smith (2003) writes that in Third World countries bureaucracy is the most powerful institution and even represents the power itself. In the fifty years of Indonesian independence, the bureaucratic environment has become the main inhibitor of Indonesian education (Lee, 1995; Beeby 1979). Nielsen (2003, p. 403) claims that during the New Order bureaucratic pressure to achieve quantitative goals:

begins in Jakarta at offices of the Directors General and other civil servants but is not limited to the central bureaucracy. In fact, the environmental press of the bureaucracy radiates to all levels of public institutions -regional and local educational offices, institutions of higher education, and even the school and classroom. It affects the way supervisors oversee schools, lecturers organize instruction, and the teachers conduct their lesson. It characterizes the culture of the educational system from top to bottom.

The idea of centralised administration, as a legacy from the colonial era, is taken for granted. Centralised administration was relevant for the colonial government to maintain the status quo and establish maximum control over all education practices throughout the country. What subsequently happened, however, was that from the 1970s the New Order government practised bureaucratic-centralistic administration in education which proved even more restrictive than the previous practices (Beeby, 1979; Darmaningtyas, 1999a).

The Ministry of Education and Culture has taken control over all matters, including detailed decisions regarding education. Appointing principals and 
teachers, managing in-service training for teachers, establishing curriculum, students' textbooks, budget allocation for every school, to name a few examples, are all administered and decided by the ministry office in Jakarta. Nielsen (2003, p. 405) argues that "this 'one size fits all' mentality caters to bureaucratic efficiency and central control, but leads to many serious misfits at the local level”. 1

Centralised administration has a direct impact on the curriculum. According to Umar (2004) another effect of the influence of the returning USeducated bureaucrats was that the new curriculum produced in 1968 had a detailed and rigid structure. The 1968 school curriculum documents were modified three times during the New Order era, in 1975, 1984 and 1994. The curriculum for all schools in Indonesia stipulates frameworks and syllabuses in all subjects. The excessive bureaucratic centralization is shown in the compiling and content of the curriculum documents.

Jazadi (2003, p. 40) claims that in the construction of the curriculum, there was no representation and involvement of stakeholders and no consultation with interest groups. The process was regarded as central office business, to be managed by the Centre for Curriculum Development MoEC in Jakarta, and conducted in a superficial bureaucratic manner which in fact was exploitative. An academic, Darjowidjojo (in Jazadi, 2003, p. 40) writes of his experience when appointed by the central office as a curriculum reviewer:

The invitation that I received was for me to become involved in preparing teaching materials for the English subject for secondary school. It stated that I would stay for five days in Puncak [in West

\footnotetext{
${ }^{1}$ For instance, when I was appointed as a state secondary school teacher in Lombok in 1993 by the MoEC office in Jakarta, the school where I worked already had four chemistry teachers, whereas the school only needed three. Other state secondary schools in the same district did not have a chemistry teacher, though they had asked for one for quite some years.
} 
Java, 40 minutes by car from Jakarta, a resort region]. This took place in the 1980s. However, on the second night of my participation, all team members were asked to gather for a closing ceremony. I was so surprised. I thought I had not even started working. How could this program be closed? Our honorarium fee was for five days, but the work was only two days. From this experience, I had the impression that the way we [Indonesian bureaucrats] worked was simply to aim to produce something so that it could have a name, so that people could refer to something.

White (1997, p. 88) finds that what is called curriculum in Indonesian schools "is more a scope and sequence that lists goals and topics for the particular course, with a content outline”. Her impression is correct. Take for example the 1984 curriculum which is the most rigid curriculum in Indonesia's education history. The documents cover all subject areas which it is compulsory to teach. The GBPP (garis-garis besar program pengajaran, the basic guide lines for teaching program) provides the basic guidelines. The GBPP consists of ten sections which are "curricular objectives, general instructional objectives, topics, sub-topics, levels, semester, teaching methods, resources, evaluation and notes” (Kopong, 1995). All these sections were determined by the Centre for Curriculum Development, but for teaching purposes the teachers have to make satuan pelajaran (unit lessons) as a preparation for instruction in the classroom. Kopong found that most teachers never prepared these. Teachers are reluctant to make unit lessons as part of their work, because the GBPP is very detailed and they only have to follow it.

Another issue which needs to be addressed is the density of the subject and lesson content. It is compulsory for year 10 and 11 secondary school students to learn 14 subject matters in 42 lesson hours a week. Drost (Kompas, 1998) states the lesson hours are the heaviest in the world. He argues that this came from the legacy of Dutch colonisation, although nowadays the general 
trend elsewhere is to lessen study time. For example, the Netherlands has 35 hours study time a week, while Germany and Australia only have 30 hours a week. The result in Indonesia is "a reliance on transferring knowledge rather than critical thinking and problem solving” (White, 1997, p. 89).

Another impact of the bureaucratic-centralistic approach is that though each state school welcomes community participation in education, this is done only in terms of free labour and supply of funds which are carefully managed by the principal. A study by Cohen (2001) found that community participation is based on regulations incorporating the 'one size fits all' method regardless of school level and size, and the type of community they served within a multidiverse Indonesian society. Although the government recognises community participation in education, it maintains the right to say how communities can participate.

A vehicle to accommodate community participation at the school level is called BP3 (acronym for Badan Pembantu Penyelenggaraan Pendidikan or educational assistance body). The BP3 is another name for an earlier body established under the Old Order as the POMG. Based on the MoEC decree number 17/O/197 (Satori, 2001), the POMG was abolished and the BP3 has responsibility for community participation such as establishing relationships and cooperation, representing parents in school activities, and collecting subscriptions from parents (Cohen, 2001; Sidi, 2001). The members of the BP3 are the school principal (as supervisor), teachers' representative, parents' representative and community members. However, because the principal has most power in the school, people who join the BP3 (parents, teachers and community members) are selected and appointed by him/her. Then, as Cohen 
(2001, p. 73) points out, "the role of BP3, in most cases, has become one of establishing fees that parents are to pay for their children to participate in school”. One of the reasons for this situation is that the normal financing patterns given by the government, especially at the secondary school level, are far from adequate to cover even basic expenditures such as paper and ink, water, electricity, chalk/marker, building maintenance and salaries for non-permanent teachers (Clark, et al., 1998; Yonezawa and Muta, 2001). A study by Supriadi (2003) found the interesting fact that money from parents through the BP3 for some state secondary schools in large cities could be higher than total funds from government in a similar period. Moreover the principal (with some of the teachers) controls the school budget of which money from parents forms a substantial part, but the school usually doesn't report the use of these funds, or make a transparent financial report to parents. According to Cohen (2001, p. 74) this kind of activity "becomes corrupted in actual implementation”.

\section{Emphasis on national security and loyalty to the state}

Another ambitious goal during the New Order was nation and character building. The emphasis on national security and loyalty to the state was addressed in a more systematic and sophisticated way than in any other period in Indonesia’s history. According to Jalal and Musthafa (2001, p. 8) this situation resulted in "education as an instrument for national economic development by way of indoctrination, which resulted in superficial uniformity”.

Every student from year 3 to year 12 has to learn a compulsory subject for 2 hours each a week called PMP (acronym for Pendidikan Moral Pancasila, or Pancasila Moral Education), designed to make a student become a 
Pancasilais person. The subject aims "to mould the thoughts, attitudes and behaviour of the students in accordance with Pancasila (the State Ideology), UUD 1945 (the National Basic Constitution), GBHN (State Guidelines)” (Jazadi, 2003, p. 45). Starting in the late 1970s, the government instructed all government agencies such as state schools to conduct a program based on Pancasila as upgrading for their employees, and it become a ritual for new teachers and new students. The upgrading for newcomers involves at least two weeks of intensive induction into how to implement Pancasila in daily life. The induction is a oneway process and consists of vague ideas drawn from state ideology. For new teachers, their probationary period was not assessed on competence in teaching and classroom management but on their understanding and attitude toward Pancasila (Nielsen, 2003).

Darmaningtyas (1999b) argues that this kind of policy contains militaristic overtones, where uniformity is required across Indonesia. At the secondary school level, public or private, students had to wear a uniform of the same design and colour, that is a white (top) and a grey trousers without exception.

From the government's point of view all of these things were seen as generating order, equality and unity across Indonesia. It also made it easier for administrators from the central office to implement order at the school level. In return, they had unquestioned power to manage subordinates. Differences were considered and dismissed as coming from dissidents and any difficulties, particularly associated with government employees, would jeopardise their future. 


\subsubsection{Education in the Reform era (1998 - to present)}

Asia’s financial crisis in 1997 had a disastrous effect on the Indonesian economy. In 1998, GDP fell by 12\%, economic growth also declined by $15 \%$ and inflation rose to around $80 \%$ (Thomas et. al., 2004: 55-56). This resulted in public anger and demonstrations by university students which finally made Suharto step down as president. In the post-Suharto, era called the Reform Era, Indonesia has had four presidents, B.J. Habibie (1998-1999), Abdurrachman Wahid (1999-2001), Megawati Soekarnoputri (2001-2004) and Susilo Bambang Yudhoyono who won office in 2004.

During the early years of the Reform Era the state system changed. In particular it moved from an emphasis on centralisation to decentralisation. In the education sector, as Supriadi (2003) notes, change was greater than any other period since Indonesia’s independence. Education was no longer fully controlled from Jakarta. The poor performance of students across Indonesia brought an awareness that the central control of schools should be kept to a minimum. It was this situation which led to seeking a better model for the management of schools, and the movement for school based management (SBM) appeared to offer a solution. There were other significant changes, such as giving the mandate for the standards for final examinations back to the central office in Jakarta, the introduction of a competence based curriculum, and a new education law which was aligned with the provision of the autonomy law. I will discuss each of these issues below. 


\section{The Autonomy Law and it consequences}

According to Surakhmad (2002, p. 6), during Habibie’s administration, because of “deep seated concerns, panic and fear regarding the potential and real threat of disintegration that was militantly voiced by several regions since the early 90s” [italics in original] the government, in response to this threat brought forward an autonomy law. Without any significant change by parliament from the document prepared by the Ministry of Home Affairs (Rasyid, 2003) the document provides for regional autonomy (Law 22/1999). Other legislation concerning fiscal balance (Law 25/1999) was prepared by the Ministry of Finance. Both laws took effect on 1 January 2001, and gave authority and funding to district governments to manage public sectors.

According to Jalal and Musthofa (2001) this kind of decentralization giving power to the district level rather than the provincial level, was a pattern under previous legislation during the New Order. The Law 5/1974, for instance, sets out the structure of the political administrative system at two levels: provincial and district, and also covers its functions and tasks. Another example is that in 1995 the government released a regulation, PP 8/1995, concerning autonomy in which one district in each province became a model of district government. Neither effort worked because the centralisation model established by the New Order was so pervasive and there was no legislation which clearly stated that central and provincial government had to devolve power to the district level.

However, Law 22/1999 is more advanced in that it eliminates the hierarchical structure from central government to provincial and district level. The head of a district has a responsibility only to the local parliament; the 
provincial government cannot direct the district anymore. Relationships with the central government relate to subsidies and supervision. The law is revolutionary and the decentralisation is ambitious in comparison with the previous system. Hofman and Kaiser (2002) describe the decentralisation phenomena in Indonesia as "Big Bang”. District governments will be given authority over public sectors such as health, education and culture, agriculture, communication, public works, industry, trade, capital investment, environment, land, cooperatives and manpower affairs (Jalal \& Musthafa, 2001). To implement their authority the district governments have two sources. Firstly, there is a subsidy from central government which comes in a block grant. This consists of a general subsidy (to support the function of the district government) and a special subsidy (given to finance certain programmes). Second, the law also permits district governments to establish local taxes based on the exploitation of natural resources, trade and services to providing internal revenue (Indriyanto, 2003a). The level of internal revenue coming from oil, mining, and forest logging determines whether a district is rich or poor. The rich districts have more flexibility to fund programs in order to service their people.

In May 2000 the government issued a further regulation, PP 25/2000, (Government of Republic of Indonesia, 2000) based on the autonomy law in order to specify more closely the tasks to be delivered to the district level. The central government holds authority in the education sector for (PP 25/2000 article 2 verse 10$)$ :

- setting standards for all age student achievement (i.e., competencies), setting the national curriculum and setting national examination/assessment system, as well as issuing instructions on these;

- $\quad$ specifying standards for learning materials;

- determining requirements for achievement and use of academic titles; 
- determining a grade/set of standards for educational operational costs;

- determining requirements for admission, transfer, certification for students from all age groups; and

- organizing and developing higher education, distance education and international schools.

The Provincial Government holds the authority to (article 3 verse 10):

- determine policy on student selection and acceptance with regards to equity issues. That is, policy regarding minority students, students from poor families and remote areas;

- contribute to provision of main study books/educational materials for kindergarten, primary, secondary and special education;

- assist in higher education management, except things related to curriculum, accreditation and appointment of academic staff;

- consider the opening and closure of colleges; and

- manage "special schools" and training centres, including teacher training institutions.

However, Indriyanto (2003a, p. 6) argues that even the decentralization already stipulated and practised in the public sector including education, "is not a guarantee that there is a clear-cut division of labour between the central government and district, and provincial government”. The role of provincial governments is to represent the central government, but in practice the law states that the district government is an autonomous body and cannot be controlled by the provincial government (Madya, 2002).

The changes are not only about a shift of power, but they "also change the whole set of management and organization arrangement in district level” (Indriyanto, 2003a, p. 3). According to Surakhmad (2002) the consequences of the autonomy law and the regulation PP 25/2000 are that each district has at least 117 tasks transferred from the central and provincial office. Public service is still far from achieving the goal of improving efficiency and effectiveness.

A study of education services in three districts from three different provinces (East Borneo, Yogyakarta and East Java) by Usman (2002) found that 
autonomy had a different meaning in every district. Where districts had rich natural resources, autonomy for the local government meant they had the means to implement their plans, but the situation was very different in poor districts. Sagala's (2003) study in two districts in West Java found that an inevitable development in the autonomy era is that local government becomes 'the new centre' with similarities to previous attitudes and practices (i.e. centralistic and bureaucratic characteristics) when dealing with the schools. A similar phenomena was also found by Soewartoyo (2002; 2003) who conducted study in two municipalities in West Nusa Tenggara and North Sulawesi provinces. Inadequate numbers of skilled personnel combined with lack of specific management skills led education services in the autonomy era to become more problematic (World Bank, 2004). As a result, managing education in many districts results not in empowering schools but rather imposing top-down approaches and unprofessionalism (Sagala, 2003; Usman 2002)

\section{School Based Management}

According to Jalal and Musthafa (2001), school based management was triggered by the World Bank report, Education in Indonesia: from crisis to recovery released in 1998. The report highlights the poor performance of Indonesian education. One of the suggestions for improvement was to give schools more autonomy to manage themselves. Following this, several task forces were formed by the National Development Planning Agency (Bappenas) and the Ministry of National Education (MoNE) and supported by the World Bank. The brief for the Task Forces was to find ways to improve Indonesian education, and this included a search for a school based management (SBM) model for Indonesian schools. Similar efforts were conducted by BPPN 
(acronym for Badan Pertimbangan Pendidikan National or Board of Consideration on National Education) and the West Java Education provincial office. All of these efforts showed that the idea of SBM was becoming popular and this gave a momentum to a change of school governance.

Several SBM models were implemented in pilot projects. Examples include Rintisan-MBS (SBM pioneering implementation) and MPMBS (manajemen peningkatan mutu berbasis sekolah or school base quality improvement management). In April 2002 the MoNE formulated a regulation setting the scene for the SBM model to be adopted by Indonesian schools. This regulation (the MoNE decree No. 044/U/2002) required every district to establish an independent body called an educational council, and a school committee at school level with authority, roles and responsibilities different from the former BP3. I will discuss each of these efforts below. The MoNE decree will be analysed further in Chapter 5 .

The Bappenas and the MoNE Task Forces. The Task Forces were powerful builders of opinion about the future shape of the Indonesian education system. Backed financially by the World Bank and worked on by the "forty best brains”, who were top Indonesian education academics, school based management (SBM) became part of the national discourse on education (Jalal \& Musthafa, 2001). Recommendations from the Task Forces were widely reported in the press, and SBM became a popular choice for reform (Kompas, 2000a; 2000b). When the Task Forces had completed their deliberations, the results were published as, Education Reform in the Context of Regional Autonomy: The Case of Indonesia. This contained their recommendations about school governance. Two chapters in the book provide frameworks for SBM developed 
by two different Task Forces. Chapter two, "Decentralization of Education and School Based Management” was written by a task force which conducted research in West Sumatra. This was based on the SBM framework from Edmonton, Canada ${ }^{2}$. Based on this research the particular Task Force advised that to implement SBM, there should be an independent body at district level called the School Board and a School Committee should be created at school level. The functions of the School Board are described as: strategic planning, policy development, programme planning, programme delivery support, monitoring, evaluation, advocacy, funding, budgeting, coordination, social development, and communication and liaison (Jalal \& Musthafa, 2001). Suggestions for the framework of the School Committee are set out in Jalal and Musthafa (2001, p. 30-31) as follows:

1. formulate school policy to encourage the development of education in the area served by the school;

2. SC must approve school plans for the year before submitting these loans to the Dinas (District Office of Education);

3. help determine the minimum service standards and provide input for amendment of the curriculum;

4. contribute to school budget planning;

5. raise alternative funding and resources to improve the quality of the school;

6. monitor school quality, appraising the impacts of education in the school, including directly viewing teachers teach in the classrooms;

7. help determine the criteria for enrolling new students, based on input from school board;

8. recommend the appointment and dismissal of the principal, teachers, and administrative personnel

9. help resolve conflict among students related to education, empowering the community to prevent students from committing negative acts outside school hours; and

10. increase liaison with the community to enhance awareness and responsibility; establish cooperation with third parties.

\footnotetext{
2 This is not a coincidence since research was collaborated and the funding was coming from CIDA (Canada International Development Agency).
} 
Another SBM framework was prepared by the education financing task force and is described in chapter 3 of the book. This task force conducted research in three provinces (West Sumatra, West Kalimantan and West Java) with the focus on establishing a model for the decentralization of finance. The task force identified two roles: a) The role of the school; at the school level the principal is the main actor in school administration and s/he has been given significant authority particularly in finance and personnel management; b) The role of the community (non-school and non-government) and they also use the terms 'school board' and 'school committee' to represent the community. For the school board they propose that its responsibilities should include teacher selection, audit of school performance, selection of new student entrants, reception of subsidies and allocation of the subsidy to schools. The main role for the school committee would be implementing policies prepared by school boards.

The BPPN. In 1999 the BPPN also supported by the World Bank, published School Based Management. The book explains the strategic implementation stages for SBM divided into short (1-3 years), medium (4-6 years) and long (7-10) term. In the long term, the BPPN proposed a new body in each school instead of the BP3 to be called a School Council to consist of community figures, the principal, teacher representatives, parent representatives, education bureaucrats, and the business sector. The responsibility of the School Council would be the selection of principals, managing money coming from parents, controlling school finance, taking part in curriculum and textbook selection, and helping and controlling the teaching and learning process (Mulyasa, 2003). 
West Java Education provincial office. Another proposal for the SBM framework came from the Education Office of West Java. This office published a report, Pedoman Implementasi Manajemen Berbasis Sekolah di Jawa Barat (A School Based Management Implementation Guide for West Java). It was prepared by academics from the Indonesian Education University (UPI) in Bandung, and was intended as a model particularly for West Java schools. Similar to the BPPN, it proposed a School Council, and insisted "that SBM without the school council is not SBM at all” (Satori et al., 2001, p. 5). Like the BPPN, the West Java model is more detailed and comprehensive though the authority of the school council is similar to that in the BPPN model.

The Rintisan MBS. In 1999, UNESCO and UNICEF co-operated with the Indonesian MoNE to commence a project called Creating Learning Communities for Children (CLCC). This was targeted at primary schools in the rural regions of some provinces. To improve school effectiveness, the project was based on what it called three pillars: a) the openness of school principal management; b) active, creative, effective and joyful learning; and c) community participation. The main activity of this project was capacity building with training for all stakeholders (principal, teachers, education district officials, parents and community members). The schools which participated in the project were given a small amount of money, with stakeholders having agreed to finance the programmes proposed in school plans (Taruna, 2001).

After two years, the success of this project in some elementary schools particularly in Central Java, was remarkable. Recognition came from national and international observers who confirmed that SBM could work in Indonesian schools. This success has led to similar projects across Indonesia, funded by 
other donors. MBE or managing basic education, funded by USAID, and REDIP by JICA (Japan International Cooperation agency) unfortunately came up with less encouraging results (The World Bank, 2004).

Taruna (2001) states that project organisation at the local level does not change the school structure. The project is "merely doing something that is not fully optimized”. He concludes that the main inhibitor stopping schools from adopting SBM is the bureaucratic environment which does not want schools to become independent (Taruna, 2003)

The MPMBS. Umaedy (1999), a senior bureaucrat at the MoNE central office, states that there are two factors which led education quality improvement under the New Order to fail. He attributes failure to the fact that the previous practices were input oriented and the strategy was macro-oriented. The former factor is based on the assumption that if every input for education such as textbooks, teacher training and buildings are available at school level this will automatically result in the outcome that is intended. The latter is about education management which, when heavily controlled by a central bureaucracy, results in serious misfits at the school level.

The MoNE also proposed a project based on effective school theory which emphasises processes in education to make schools creative and autonomous. Unlike the Rintisan MBS, the MPMBS project focuses on junior high and secondary schools across Indonesia. For the first phase in 1999, 700 schools participated in the project, with training for school principals regarding strategic management conducted by the provincial educational offices. A school which wanted to join a project had to submit a proposal with the school plan to the central office, and if accepted, it received a block grant under a scheme called 
BOMM (bantuan operasional manajemen mutu, quality improvement operational assistance). The BOMM is intended to be like 'seed money' to cover a portion of the total operational cost (Indriyanto, 2003b) of a quality improvement program.

There are two reports available related to these efforts which came from the central office. One report is about case studies in a state secondary school in Surabaya, East Java (Subijanto, 2000), and the other is a monitoring report of this project in 232 state junior secondary schools in 24 provinces (MoNE, 2001). Both reports outlined the schools' goals as stated in their vision statements, which were mostly about the enhancement of the academic achievements of their students. What is interesting in both reports is that to achieve these goals schools relied on extra teaching activities for students who would face national examinations. Such activities had been regularly conducted and funded by the school (Subijanto, 2000; MoNE, 2001). This option was chosen because most principals found it difficult to understand the MPMBS and even harder to write a plan to improve school quality (MoNE, 2001). Moreover, the bureaucratic environment in the school has meant that transparency was not easily incorporated in the implementation process (MoNE, 2001). Subijanto (2000) found that parents, teachers and school staff said that only the principal knew about the programme. The training which had been given to the principal was intended to transfer the knowledge and involve other parties in the school, but unfortunately this has increased the principal's bargaining position in school more than prior to the project.

In addition, MoNE (2001) also criticises the MPMBS which was designed and executed in the central office in the Reform Era. This programme 
was still being practised indiscriminately in Indonesian schools producing wide variety in its implementation. The point that the project should be a transition model to school based management was missed.

\section{Others Development in the reform era}

Some significant changes in the Indonesian education system took place in the Reform Era. Regarding the final examination, the mandate to graduate students (year 9 and 12) which was given to school in 1968, was pulled back to central office. The MoNE stipulated that students can continue their education at the upper level only if their mark was not below the threshold number in three subjects (Indonesian, English and Mathematics). In 2003 when the policy began, there was some resistance to the threshold mark, which was 3 for a range of 0 to 10. However, when in 2004 the threshold level to pass school was raised to 4.0, there were many demonstrations and lobbying in opposition to the policy. The fear that many students could not pass the exam in 2004 eventually did not happen, because the central government used a conversion table in order to raise the score and this resulted in more students scoring above the threshold level (Sihombing, 2004). Further, the MoNE was also allowing re-examination till 2005 in order to give many more students another chance to pass the exam. However starting in 2006, the threshold trend was rising and no remedial examinations were available anymore. This made final examinations to be perceived as a 'killing ground' for students (Kompas, 2006a). Some critics observe that imposing this kind of method is unfair because of the multi diversity of infrastructure and quality of Indonesian schools (Rosyid, 2006). However, the MoNE believes that the examination is the best method to improve educational 
quality because it pushes students and teachers to work harder, compared to nearly thirty years practice where students could pass whatever their result were.

The central government also introduced a competence based curriculum (KBK) in 2004. The construction of this curriculum was significantly different from the previous system, because it involved consultations with stakeholders, pilot-testing in some schools, and some training for teachers and principals. The central office promised that the new curriculum framework would give more flexibility to teachers. However, an early implementation study clearly showed that most Indonesian schools were not ready for the KBK. Also the infrastructure to support the programme was inadequate. There were also criticism that the curriculum content appeared to be un-changed; the only change being in the organisation of the syllabus. The MoNE retracted the policy and stipulated a new curriculum, called Kurikulum 2006, a revised version of the KBK which was suggested by a new body, the National Education Standardisation Board.

In the Reform era, the Indonesian parliament had passed two new laws regarding education. First, the education system law (Law 20/2003) which, unlike previous laws, introduced changes from the use of a centralistic paradigm; and the teachers law (Law 14/2005) which was proposed for five years by the PGRI. Both laws have an ambitious agenda which in fact is difficult to reach. The Law 20/2003 for instance, stated explicitly that the education sector must have $20 \%$ of proportion in the national budget. Five years after the Law was introduced, the stipulated education budget had never reached $10 \%$ of the total budget. The teacher law states that Indonesian teachers should have a bachelor degree (or at least four years study at tertiary level) and promises to double the salary if teachers also pass certification examination. Currently, with more than 
2.7 million teachers, only 35\% have undergraduate degrees, which means that to retrain the rest of the teachers is a huge task due to the large numbers and diverse locations (Kompas, 2006b).

\subsection{Conclusion}

In this chapter, I discussed the historical development of the Indonesian education system. The administrative centralization of the education system was a legacy from Dutch colonialism. This centralised system was changed after the New Order had ended. In terms of school governance, a policy of decentralisation was introduced following a search for alternative governance models, resulting in the adoption of school based management. However, the SBM which has been adopted is not standard. Instead, several configurations of the SBM model have been tried in Indonesian schools.

The next chapter will provide a literature review related to educational decentralisation and school based management issues in an international context. 


\section{Chapter 3}

\section{REVIEW OF THE LITERATURE}

\subsection{Introduction}

This chapter is a review of the international literature on educational decentralisation and school based management. The chapter explores the reasons for devolving authority in education and its consequential impacts, and includes experiences of school governance in developed and developing countries. As well, the chapter addresses issues of power and authority levels in decentralisation.

\subsection{Educational decentralisation framework}

Daun (2002, p. 75) states that policy of the educational decentralisation "has become the most commonly implemented restructuring policy". It can be identified in both developed and developing countries (Bulock and Thomas, 1997; Abu-Duhou, 1999; Fullan and Watson, 2000). This policy has been initiated by democratic governments, such as in Australia and the United States (Murphy and Beck, 1995), autocratic military regimes, such as in Argentina and Chile (Fiske, 1996, Schieffelbein and Schieffelbein, 2000), and even by a country with a rigid centralisation ideology like China (Hawkins, 2000).

The implementation of educational decentralisation varies in term of scale. It happens at a district level in Edmonton, Canada (Brown, 1990) and Chicago, USA (Bryk, Sebring, Kerbow, Rollow, and Easton, 1998); at the state level in Victoria, Australia (Abu-Duhou, 1999) and Kentucky, USA (Lindle, 1996); and at the nationwide level in the United Kingdom (England and Wales) (Bulock and Thomas, 1997) and New Zealand (Wylie, 1995). 
Consequently, the many varieties of the policy make it difficult to generalise about it. However, in general terms, decentralisation is about the shifting of authority and responsibility from one level of government to a lower one. Nevertheless the term decentralisation does not have an exact single meaning that is easily understood by all who practice it. So it is helpful to explain the concept by considering four dimensions of emphasis: (1) degree of transfer, (2) breadth of transfer, (3) location of transfer, and (4) functions transferred.

\subsubsection{Degree of transfer}

In the literature on educational decentralisation policy, the degree of transfer within public institutions is categorized into at least three types, namely deconcentration, delegation, and devolution (Rondinelli, Nellis and Cheema, 1983; Fiske, 1996; Abu Duhou, 1999; McGinn and Welsh, 1999; Daun 2002). First, according to Abu-Duhou (1999, p. 24-25) deconcentration is "the handing over [of] some amount of administrative authority or responsibility to lower levels within central government ministries and agencies, and it is shifting of the workloads from centrally located officials to staff or office of the national capital or centre”. This is the weakest form of degree of power transfer (Fiske, 1996), because the centre doesn’t devolve power. As McGinn and Welsh (1999, p. 18) note, “deconcentration reforms shift authority for implementation of rules, but not for making them”. Deconcentration is usually supported by financial grants and local governments have to plan and implement programs and projects which are adjusted to local condition, based on the guidelines laid down by the central office. In Indonesia, most public sectors including education prior to the reform era, have been practising this kind decentralization which has made provincial governments more powerful than district governments. 
Second, delegation refers to the transfer of decision-making authority and managerial responsibility for certain functions or tasks from a higher to lower level which remain indirectly controlled by a central government (Rondinelli et al., 1983). Usually delegation takes place for certain narrow functions of government service with a relatively broad responsibility that is often conducted outside the bureaucratic hierarchy. Similarly to deconcentration, in delegated arrangements the full responsibility remain in the hands of the central government, and if it wishes it can pull back its authority and responsibility (Fiske, 1996).

Third, as defined by Rondinelli et al. (1983, p. 24) devolution is "the creation or strengthening -financially or legally- of sub-national units of governments, the activities of which are substantially outside the direct control of the central government”. This means, devolution is the far-reaching form of decentralisation, and the one in which most transfer of power is involved. It is intended to be permanent and cannot be withdrawn without some legal justification (Brown, 1990; McGinn and Welsh, 1999). In addition, devolution involves greater political and fiscal decentralization compared to deconcentration and delegation which usually emphasises administrative decentralization. This means that with devolution, local governments with recognized geographical boundaries can exercise their authority more widely and significantly, thereby limiting the national governments role to a supervisory one in certain aspects. Fiske (1996, p. 20) points out that devolution named as political decentralization is the most complex option because it "involves a multitude of stakeholders, both inside and outside the government, all of whom will have interests to protect or pursue”. 


\subsubsection{Breath of transfer}

Commitments by national governments to decentralize a range of their public sectors vary. In some cases the transfer of powers is limited to a few government bodies. In others, nearly all public sectors are involved. For example, in Morocco decentralization is limited to the education sector (Cohen, 2004, personal communication). In Chile, in addition to education, the health sector also experienced decentralization (Burki, Perry \& Dillinger, 1999). Meanwhile, in Malawi, according to Davies, Harber and Dzimadzi (2003), the civil service at local levels administers up to six different sectors. Meanwhile, the decentralization that was introduced in Indonesia during the reform era was massive, involving nearly all public sectors at the district level, except for the monetary and fiscal sectors, defence and security, foreign politics, justice and religion, which remained in the hands of the central government in the capital (Jalal and Musthafa, 2001).

\subsubsection{Location of transfer}

The transfer of authority in education can take place at several sub-national levels. The possible locations of sub-national authorities include states, provinces or regions; districts, municipalities or counties; sub-districts, villages or schools. In Table 3.1 Daun (2002) summarizes the possible levels of decentralization in education in countries that have implemented the policy.

In the case of New Zealand, one goal of its decentralisation policy was to eliminate the middle management level to ensure that central government was linked directly with the school (Wylie, 1995; Fiske, 1996). Whereas in Victoria, Australia, education remains under the jurisdiction of the state government. Consequently, the location of transfer is at the state level (Abu-Duhou, 1999). In 
another situation, Davies et al. (2003) observed that in Malawi, the transfer of power in education is from the central government to the district level. By contrast, Caldwell (1994) gives an example of centralization occurring from the schools level back to the district level in California in the 1980s, because of financial constraints.

Table 3.1. Baselines and Levels of Decentralization and Centralization

\begin{tabular}{|c|c|c|c|c|}
\hline \multirow{2}{*}{$\begin{array}{l}\text { Level to which } \\
\text { decentralization/ } \\
\text { centralizal rion is } \\
\text { taken }\end{array}$} & \multicolumn{4}{|c|}{ I evel from which decentralization/centralization starts } \\
\hline & $\begin{array}{l}\text { Central/national/ } \\
\text { federal }\end{array}$ & $\begin{array}{l}\text { Regional/ } \\
\text { state/Länder }\end{array}$ & $\begin{array}{l}\text { Municipality/ } \\
\text { District }\end{array}$ & School \\
\hline Central/national & - & $\begin{array}{l}\text { Centralization } \\
\text { Canada }\end{array}$ & Australia, UK & \\
\hline $\begin{array}{l}\text { Region/state/ } \\
\text { Länder }\end{array}$ & $\begin{array}{l}\text { Brazil, } \\
\text { Colombia, } \\
\text { France, Finland, } \\
\text { Mozambique, } \\
\text { Spain }\end{array}$ & - & & \\
\hline $\begin{array}{l}\text { Municipality/ } \\
\text { district }\end{array}$ & $\begin{array}{l}\text { Czech Rep. } \\
\text { Lnited Kingdom } \\
\text { Sweden } \\
\text { Tanzania }\end{array}$ & Sweden & - & $\begin{array}{l}\text { Cases } \\
\text { in the } \\
\text { US and } \\
\text { Latin } \\
\text { America }\end{array}$ \\
\hline School & $\begin{array}{l}\text { Columbia } \\
\text { Sweden } \\
\text { New Zealand }\end{array}$ & $\begin{array}{l}\text { Australia } \\
\text { Germany } \\
\text { Sweden }\end{array}$ & $\begin{array}{l}\text { Denmark } \\
\text { Finland } \\
\text { Sweden. United } \\
\text { Kingdom, } \\
\text { some states in } \\
\text { United States }\end{array}$ & - \\
\hline
\end{tabular}

(Source: Daun, 2002, p. 76)

\subsubsection{Functions transferred}

Regarding the transfer of functions there are a numbers of possibilities, including giving all function to schools or sharing each function with separate levels of government. Such functions as personnel management, testing, procurement, curriculum, student management, financing, training, to name a few, are performed by government institutions. A study by Rideout and Ural (1993) as in Table 3.2, 
shows the distribution of functions in ten developed and developing countries, as this relates to decision making with regard to certain functions.

This table indicates that some decisions are still exercised significantly at the central government level. Examples included school organisational structure, minimum requirements and official languages used in teaching, and some others. On the other hand, management functions such as discipline and teachers evaluation are significantly undertaken at the school level.

Table 3.2. Location of Decisions by Category of Decision

\begin{tabular}{|c|c|c|c|c|}
\hline Category & $\begin{array}{c}\text { Central } \\
\%\end{array}$ & $\begin{array}{c}\text { Regional } \\
\%\end{array}$ & $\begin{array}{c}\text { District } \\
\%\end{array}$ & $\begin{array}{c}\text { Local } \\
\%\end{array}$ \\
\hline \multicolumn{5}{|l|}{ Governance } \\
\hline Policy & 90 & 40 & 10 & 10 \\
\hline Planning & 90 & 40 & 10 & 30 \\
\hline Implementation & 80 & 30 & 50 & 40 \\
\hline \multicolumn{5}{|l|}{ School Organization } \\
\hline Structure & 90 & 10 & 10 & 0 \\
\hline Minimum Requirements & 90 & 10 & 0 & 0 \\
\hline \multicolumn{5}{|l|}{ Financing } \\
\hline Recurrent & 80 & 50 & 30 & 50 \\
\hline Development & 90 & 40 & 30 & 60 \\
\hline \multicolumn{5}{|l|}{ Training: } \\
\hline In-service & 80 & 50 & 20 & 30 \\
\hline Pre-service & 70 & 50 & 10 & 0 \\
\hline Management & 60 & 40 & 60 & 50 \\
\hline Qualification Standards & 90 & 20 & 0 & 0 \\
\hline \multicolumn{5}{|l|}{ Curriculum: } \\
\hline Subjects & 90 & 30 & 0 & 0 \\
\hline Content & 90 & 20 & 10 & 20 \\
\hline Textbooks & 80 & 20 & 10 & 30 \\
\hline Textbook Provision & 70 & 30 & 20 & 40 \\
\hline Language Policy & 100 & 20 & 10 & 0 \\
\hline Instructional Methods & 70 & 30 & 20 & 20 \\
\hline Evaluation of Teachers & 60 & 50 & 60 & 70 \\
\hline \multicolumn{5}{|l|}{ Monitoring: } \\
\hline Accreditation & 70 & 30 & 0 & 20 \\
\hline Examinations & 70 & 30 & 30 & 90 \\
\hline Pupil Promotion & 70 & 0 & 30 & 70 \\
\hline Discipline & 10 & 10 & 30 & 90 \\
\hline Data Systems & 60 & 50 & 50 & 60 \\
\hline School Evaluation & 90 & 40 & 40 & 30 \\
\hline \multicolumn{5}{|l|}{ Research } \\
\hline Needs & 90 & 30 & 10 & 20 \\
\hline Conduct & 80 & 50 & 20 & 20 \\
\hline Implementation & 60 & 20 & 30 & 10 \\
\hline
\end{tabular}

(Source: Rideout and Ural, 1993, p. 108) 


\subsubsection{Power and authority}

According to Daun (2002) there is a paradox when central governments decentralise certain powers. This is because decentralisation and other restructuring developments are always initiated from above. On the one hand it seems logical for power to be located at the top level government, but on the other hand, it can also make sense for power to be given to lower levels. But it is the concepts of power and authority which are at the heart of decentralisation, if the transferring of power is to make sense. Weber, in his classic sociological analysis of power, notes that besides power there two other important concepts: authority and legitimacy.

Power, in simple terms, refers to the ability to do something or to have control over people and activities. When "power is granted by consent" (Nieuwenhuis, 2004, p. 4) it is what we call authority. In terms of public organisations, consent is obtained through a range of means, such as constitutions, legislation, regulation or decrees that enable people who hold positions to have a justification for their authority. When this happens, it is called legitimacy. Moreover Nieuwenhuis (2004, p. 4) writes that "legitimate power may thus be seen as the ability to exert influence in the organisation beyond authority, which is derived from position”.

Undoubtedly, the formulation of legislation or regulation about decentralisation generally arises from a political struggle at all levels of government. Often, the stipulated regulation is outlined to stakeholders as the framework which will "constrain and shape decisions and behaviours of [the] organisation’s members” (McGinn and Nash, 1999, p. 17). Wirt, Mitchell and Marshal (1985) further notes that the political culture in a country influences the process of policy development as well as the content and quality of educational policies. Consequently, the nature of a regulation that allocates power to certain 
levels but not to others, reflects the social reality of power within the society. Gershberg (1999) proposes that there are two strategic choices in terms of legislating an educational reform process. These are shown in Table 3.3. The table depicts a situation with high legislative involvement where a certain legal framework is processed, involving political procedures, and a low legislative involvement where change in schools is not based on specific legislations (e.g. Nicaragua).

Table 3.3. Initial strategic dichotomy faced in education reform

\begin{tabular}{|c|c|c|}
\hline & Emphasizes & Disadvantages \\
\hline $\begin{array}{l}\text { High } \\
\text { legislative } \\
\text { involvement }\end{array}$ & $\begin{array}{l}\text { - consistency } \\
\text { - comprehensiveness } \\
\text { - clean sense of final outcomes }\end{array}$ & $\begin{array}{l}\text { - may maximize opposition } \\
\text { - builds in unforeseen problems } \\
\text { - prevents learning by doing } \\
\text { - enforces a one-size-fits-all } \\
\text { approach } \\
\text { - subsequent changes may be } \\
\text { costly } \\
\text { - may emphasize pork-barrel } \\
\text { politics (i.e. government } \\
\text { funding for projects designed } \\
\text { to win votes) }\end{array}$ \\
\hline $\begin{array}{l}\text { Low } \\
\text { legislative } \\
\text { involvement }\end{array}$ & $\begin{array}{l}\text { - operational viability } \\
\text { - local responsiveness } \\
\text { - learning by doing } \\
\text { - subsequent changes may be } \\
\text { less costly } \\
\text { - putting reform in the hands of } \\
\text { education officials }\end{array}$ & $\begin{array}{l}\text { - reform vulnerable to reversal } \\
\text { or abandonment } \\
\text { - may create confusion or lack of } \\
\text { transparency } \\
\text { - scandal/mistakes can doom } \\
\text { entire reform }\end{array}$ \\
\hline
\end{tabular}

(adapted from Gershberg, 1999, p. 64)

The forms of power and authority which are formulated in terms of decentralisation regulations often have potential for creating conflicts, confusions and misunderstandings. According to Daun (2002, p. 80) this is because of “(i) the unclear definition on who decides what; and (ii) the interpretation of the new rules”. 
In agreement, Elmore (In Daun, 2002) in the United States and Wylie (1995) in New Zealand both noted that ambiguity is often seen regarding the responsibility and authority of various levels of governance. Consequently, Wylie (1995) and Fulan and Watson (2000) suggest that to avoid confusion and tension at the implementation stage, it is desirable that there is clarity in the formulation of rules, regulations and decision-making authority.

\subsection{Reasons for decentralisation}

According to McGinn and Welsh (1999), education in most countries the past traditionally conducted in a decentralized way and administered locally. With population growth and urbanization, strengthened by nationalism and economic competition and particularly "in the pursuit of improved quality and higher efficiency through standardization, most education systems became more centralized” (McGinn and Welsh, 1999, p. 25). In the case of developing countries, most governments had already inherited centralised education systems which were usually taken for granted.

However, within the education sector, particularly since the 1980s, decentralisation policy became a global phenomenon. For many developed countries, this can be seen in one respect as a kind of return to an earlier past. Undoubtedly, the decentralisation movement had its own local purposes. Fiske (1996), explains that for the following countries the principal intentions included: Spain's attempt to cure regional problems; Brazil's effort to promote local autonomy; India's to foster democracy and New Zealand's to eliminate the middle management level. Another writer, Lauglo (1995), suggests that the reasons for decentralising the education sector are based on two broad categories: political, and quality and efficiency. Daun (2002) adds that there are three main sources of 
decentralisation: the free market philosophy, political-participatory philosophy and organization theory. Relating to the school-based management movement, Caldwell (1994) proposes five reasons: (a) efficiency and effectiveness in the delivery of public services; (b) ideology that embraces a faith in the market mechanism in the public as well as the private sector; (c) equity in the allocation of scarce resources; (d) a broad societal valuing of empowerment of the community; and (e) findings in the research on school effectiveness and school improvement.

In the next five sub-sections, Caldwell's classifications for decentralisation are further explored. While the categories are presented discretely, in reality they are interrelated.

\subsubsection{Efficiency and effectiveness in the delivery of public service}

The changing of the world situation, mainly in the Northern hemisphere, after World War II, led to public dissatisfaction in education (McGinn and Welsh, 1998; Daun, 2002). It became clear that large bureaucratic organisations which were administering public education did not have the capacity to maintain quality because of the high rate of student enrolment (McGinn and Welsh, 1998), and "tended to be inefficient and unresponsive to changing circumstances” (Bray, 2000, p. 8). At the same time, the private sector had shown successful examples with its restructuring efforts, devolving authority to lower levels, retaining strategic decisions at the central levels, and being more client-centred in their operations.

The changes above had led to the adoption of efficiency and effectiveness principles in running public institutions. In the education sector, school-based management policy became associated with the efficiency and effective use of public resources. According to Caldwell (1994), besides the effects of recession or financial crisis, mismanagement of public money has in the past been the main 
reason why SBM policy was so tempting for central governments. Moreover, it is believed that practising SBM will reduce significant government spending on public education systems, which in turn will reduce public debt. This was the case in the state of Victoria, Australia, where a restructuring policy has reduced central office staff considerably and schools are directly given nearly $90 \%$ of their operational costs.

There are also other rationales. It is argued that local people know better and are able to be more responsive to their own needs. Locating authority locally seems more efficient, compared with decisions from central governments which often miss their targets and take a longer time to implement. People who work in local schools, or who live locally, the argument goes, will efficiently gather information relevant for their own purposes, ranging from pedagogical to school infrastructural issues. This kind of information is more reliable and will lead to effective decision-making by school stakeholders in terms of public service delivery.

Decentralized decision making happens with greater regard for outputs rather than inputs. Often such organisational behaviour is accompanied by a framework from central authority, which allows freedom to be given to local stakeholders to choose how and where to allocate resources. Certainly this policy orientation has the potential to lead to empowerment of local capacity to accept responsibility, and be aware and careful in decision making.

\subsubsection{The market mechanism}

Within the sphere of education, the market mechanism is understood in a particular way. According to Ball (1990), there are five elements: parental choice, competition, diversity, funding and organisation. With a centralised policy system, 
it is common to see the imposition of mandatory pupil entrance to a specific public school or state-approved school in a designated area. Such a policy requires parents to send their children to the nearest school in the area. Under a market economy policy, parents are given power of choice, permitting them to decide which educational institution their children should attend. Under such a policy, parents are described as consumers, implying that they have a personal interest and stake in their children's education. As consumers, it is also assumed that parents will also have much more information relevant to their children's interests and abilities. Consequently, one does not have to be a professional to find suitable schools for one’s children (McGinn and Welsh, 1999).

A consequential effect of parental choice is competition between schools. Each educational institution will compete to attract as many students it can enrol, not only in order to survive, but to satisfy its consumers. Within a market economic policy, student enrolment is not merely a function of physical and economic access, but it also includes perceptions about quality and relevance. Managing perception becomes a key role as schools become much more public relations friendly; more aware of the value of positive press publicity; and learns to record and highlight their activities and achievements better. It is hoped by its advocates, that competition between schools, aiming to attract students far from their own locations will benefit consumers as well as the nation.

Another significant aspect to note in a market economy policy relates to the availability of diversity. According to McGinn and Welsh (1999, p. 44) in educational terms there are three conditions that make markets exist: 1) there is variety in the quality and content of education provided; 2) consumers are informed about options; and 3) consumers are able to choose among the options. In contrast, 
if all schools are giving the same service and are using the same national curriculum, then there is no market. Moreover, options are also available whenever another school is very expensive or is located very far from students' homes.

One of the main characteristics of the market mechanism is that the funding allocated to schools is based on numbers of students enrolled. The concept of a 'voucher system', originating from Milton Friedman, may be implemented, where “each person would be given a non-transferable education voucher to be used to buy education from amongst competing institutions which would then depend on these vouchers for their income” (Lauglo, 1995, p. 20) . It may also include parents having the opportunity to use the voucher to send their children to private schools, whenever they are willing to pay the difference. Undoubtedly, this system strengthens parents' bargaining position, while making schools depend heavily on parental choice. The system also makes the schools' ability to deliver overall service, retain staff, acquire facilities and equipment, linked to their ability to attract consumers, otherwise they will not survive.

The final issue for schools in a market mechanism relates to them as organisations. The income schools generate via enrolled students becomes the actual budget figures, over which schools have authority. As a result, schools are likely to become more responsible for using the budget according to their needs. Often, these range from recruiting teaching and administrative staff, to paying for maintenance costs and needed equipment. Such a situation promotes change to schools as organisations. It also makes the school principal's role more like that of a chief executive officer in the business sector.

The explanation above is characteristic of economic rationalism and the coalition of market liberals and conservatives, sometimes also known as the 'New 
Right' (Ball, 1990; Caldwell, 1994; Marginson, 1993). Several developed countries have implemented aspects of the New Right agenda in one form or another. In the United Kingdom, for example, under the conservative governments led by Margaret Thatcher and John Major, new education legislation was introduced that produced a shift in educational authority, such as "local management of schools, grant maintained schools, the virtual privatisation of the inspectorate, and national testing of students with the public release of 'league tables' enabling parents to compare schools on outcomes for students” (Caldwell, 1994, p. 5305). The introduction of school global budgets in the state of Victoria, Australia, by a Liberal government in 1992 (Abu-Duhou, 1998); radical decentralisation to school level in New Zealand with 'Tomorrow Schools' in late 1980s (Wylie, 1995); or the implementation of a school-based budgeting project in Alberta, Canada (Brown, 1990), had all shown that the New Right ideology was influential in public policy thinking.

In the United States, decentralisation was widely practiced during the Reagan presidency in the 1980s, and was strengthened and popularised with the work of Chubb and Moe (1990). They claim that schools run by professionals are necessarily a form of tyranny, and when schools are directed through democratic means, this is essentially coercive. Instead, "the market is claimed to be the best way to use information about what people want and what satisfies them” (McGinn and Welsh, 1999, p. 43). These ideas contributed to the emergence of the 'charter school’ system in various American states.

However despite claims by proponents of the market mechanism of improved efficiency, effectiveness and quality of education, critics point to some negative effects of the policy. For instance, from research in the United Kingdom, Ball (1990) found that an emphasis on parental choice based on school performance 
has led schools to attract more able students by strengthen 'superficial' impression management. Less motivated and less able students tended to be enrolled in schools which are labelled as lower in quality because middle class parents exploited this situation for their own purposes. With differentiation of students' ability come issues of social class inequality.

Another critic, Lauglo (1995) argues that the basic principle of the market mechanism is to rely on survival and expansion of the providers to make sure that efficient quality services are always delivered. In reality, when "the most competitive schools have no surplus of places or if they choose not to respond to demand by increasing their supply, the net result may be to reinforce inequalities in selectiveness among the existing schools, thus reinforcing status hierarchies among them” (p. 21).

\subsubsection{Equity in the allocation of scarce resources}

The practice of public school systems where uniformity is widespread basically reflects equality rather than equity. This is because in a centralized system, "education improved in quality as a direct result of the ability to standardize the content and provision of education” (McGinn and Welsh, 1998, p. 24). However, the unique learning needs of individual students also cannot be fulfilled by a market driven system. In addition, students with different characteristics such as minority groups are not served better in the public school system that emphasise equality. Equity arguments can also be made with respect to policies that are intended to close the gaps with education services between city and rural, rich and poor, male and female, as well as differences between ethnic minority and indigenous people and mainstream groups. 
One practice that has been implemented is the provision of additional budget measures which take into consideration particular characteristics of students. When a school has students from ethnic minority groups for instance, the state gives the students through the school a bigger allocation than is given to the mainstream students. In this way, the school practices positive discrimination.

\subsubsection{Empowerment of the school community}

Daun (2002) argues that from a de-institutionalist perspective, a big centralised and bureaucratic public service institution such as the school, is repressive, inflexible, rule-bound and undemocratic. Whereas when, through decentralization policy, a school and its local community are empowered, this allows for community "participation in organizational and political life". Ultimately this can be "seen not only as instrumental but also as a value in itself” (p. 73).

Participation by a local community in a particular state school is the popular justification for decentralising in the SBM form. However, Bray (2000) points out that participation or involvement tend to be weaker forms of arrangements than partnerships. This is because "partnership implies more active and committed involvement. Partners share responsibility for a joint activity, whereas participants may merely co-operate in someone else’s activity” (p. 5).

The school partner which is the community has, according to Wolf (1997 in Bray, 2000) four characteristics, which are: 1) a network of shared interests and concerns; 2) a symbolic or physical base; 3) extension beyond the narrowly-defined household; and 4) something that distinguishes it from other similar groups. People who are grouped in a school community range from the principal, teachers, school administration staff, students, parents, alumni, individuals who live nearby the 
school's location, representative of religious organizations, commercial bodies, NGOs, and so on. In the case of elementary schools, geographical communities have relatively more influence compared to secondary schools. This is because students of the former mostly come from an immediate catchment or enrolment area, whereas in the latter the students usually come from kilometres away and also may be from more diverse backgrounds. In terms of school based management policy, partnerships allow for optional or mandatory policy options, where a range of possible devolved authority measure can be exercised. Further explanations regarding this will be given in the next section.

The proponents of community involvement in education argue that there are several outcomes from it. According to Bray (2000) these include shared experiences and expertise, where each party can give their knowledge and skills to solve the task. There is also mutual support, especially when obstacles emerge and partners can provide each other with support. Moreover, as a division of labour, some specific jobs will be accomplished best by one party and others can finish the rest. Community involvement may also result in increased resources, whereas as group the community is bigger than the sum of all parts in terms of human, material and financial resources. Further, community involvement involves an increased sense of ownership, because people who take part in participatory decision making tend to feel a greater sense of belonging to any resolution they are involved in. This also means an extended reach, where each party can bring their voice and experiences to extend initiatives. An increased effectiveness can be achieved as a result of each party bringing their own perspectives with good information about local conditions and situations, which enriches each other's knowledge, thereby leading to good and accurate decision-making. Lastly, in evaluation and monitoring, 
involving many parties will complement others' effort to evaluate and monitor progress thereby providing wider suggestion for adjustments and improvements.

Partnerships may also experience negative consequences such as self interest, factionalism, and capability problems. Self interest, for instance, is the main motive in partnerships and when parties who are involved are not fully aware of the interests of others, issues of quality may be compromised. Factionalism emerges when one party becomes a majority and prefers to advance its own agenda at the expense of others. Often, when partners are incapable of resolving conflicts satisfactorily, the partnership breaks down.

Empowering the school community became more evident in many countries. For example in the United States, Caldwell (1994) writes that in Dade County, Florida, devolving power from state governments to district and then to school levels has been pursued because of the importance given to teacher involvement in decision making. In New Zealand, school boards were re-empowered with the structural reform in 1989, when parents were given new responsibilities. This trend towards greater empowerment has also been evident in developing countries in Africa, Asia and Central America (Bray, 2000).

\subsubsection{Research on school effectiveness and school improvement}

Since the 1960s several education reform efforts, mainly in the Western world, have been implemented in order to increase educational quality. The reforms have included changes of curriculum and syllabus, new teaching methods in the classroom and adding more teaching resources to schools. As noted by Fullan (1991) these initiatives have not often achieved what was intended. One explanation 
for this has been that the reforms have not been based on careful research about schools and their interactions.

Abu-Duhou (1999) observes that in the 1980s, research on school effectiveness and improvement was about effective school reforms. Cheng (1996, p. 43) for example, points out that "to improve education quality, it is necessary to jump from the classroom teaching level to school organization level, and reform the structural system and management style of schools”. From the beginning, the school based management approach has had its scientific justification.

Furthermore in the United States, according to Caldwell (1994), there were two research reports that influenced the direction of school reforms. The first one was a report from the National Governors’ Association in 1986 entitled Time for Results. The second one was a book written by two researchers, Chubb and Moe, published by the Brooking Institution in 1990, entitled Politics, Markets and America's Schools. Those publications undoubtedly recommended significant ways to change schools based on research their authors saw as appropriate.

\subsection{School Based Management}

Ainley and MacKenzie (2002, p. 1) write that in the last thirty years “decentralization of decision making, increasing local authority and enhanced autonomy of schools have been common features of the reorganization of public education”. This movement in North America, and by UNESCO, was labeled as school based management (see for example Brown, 1990; Leithwood and Menzies, 1998; Abu-Duhou, 1999). Meanwhile in the UK, it is more commonly known as the Local Management of Schools (LMS) (Bullock and Thomas, 1997). The terminology describing the policy is varied. Murphy and Beck (1995) have 
identified other terms, including school-site autonomy, school-site management, school-centered management, decentralized management, school-based budgeting, and shared governance.

Like decentralisation, the characteristics of school based management (SBM) and issues related to it can also vary depending on different perspective. Beck and Murphy (1998, p 359) for instance, claim that SBM is "a complex phenomenon that may be implemented in a variety of ways”. Several other writers have already categorised SBM (Murphy and Beck, 1995; Leithwood and Menzies, 1998) and have identified key central elements, which are discussed in the sections which follow. They include definition and models, emerging formal structures, and effects of SBM particularly regard to students learning.

\subsubsection{Definitions and resources transferred}

From their extensive research on school based management in North America, Murphy and Beck (1995, p.13) conclude that many definitions of it emphasise "a major shift in the locus of decision-making responsibilities and alterations in the members of the decision making cast”. Similarly, in perspective from an Asian country, Cheng (1996, p. 44) defines school based management as follows:

that the school management tasks are set according to the characteristics and needs of the school itself and therefore school members (including board of directors, supervisor, principal, teachers, parents and students, etc.) have a much greater autonomy and responsibility for the use of resources to solve problems and carry out effective education activities, for the long-term development of the school.

Another definition comes from Cadwell and Spinks (1988, p. 5) who see SBM as:

a school in a system of education to which there has been decentralised a significant amount of authority and responsibility to make decisions related to the allocation of resources within 
centrally-determined framework of goals, policies, standards and accountabilities.

The definitions above show that in schools which practice SBM policy, transfer of authority takes place, giving school's some degree of decision making. In other words, autonomy is based on stipulated regulations. This is different from independent, private or non-state schools which are not supported regularly by public funds (Caldwell, 1998). These latter schools operate as self-governing schools.

The range of resources that are devolved to SBM can also vary. Wohlstettter and Odden (1992) list at least three areas that schools minimally have authority over: budget, curriculum and personnel. More broadly, Caldwell and Spinks (1988, p. 5) explain that SBM authority can involve:

knowledge (decentralisation of decisions related to curriculum, including decisions related to the goals or ends of schooling); technology (decentralisation of decisions related to the means of teaching and learning); power (decentralisation of authority to make decisions); material (decentralisation of decisions related to the use of facilities, supplies and equipment); people (decentralisation of decisions related to the allocation of people in matters related to teaching and learning); time (decentralisation of decisions related to the allocation of time); and finance (decentralisation of decisions related to the allocation of money).

In addition, Bulock and Thomas (1997, p. 7) suggest there are four further powers that a public school can exercise:

(i) admissions: decentralisation of decisions over which pupils are to be admitted to the school; (ii) assessment: decentralisation of decisions over how pupils are to be assessed; (iii) information: decentralisation of decisions over the selection of data to be published about the school's performance; (iv) funding: decentralisation of decisions over the setting of fees for the admission of pupils.

It appears that prior to the SBM movement, public schools in most countries were rigidly controlled, without much scope for those in leadership in governance roles to exercise full responsibility. 
However, many empirical studies about SBM have shown that the authority transferred to schools is often restricted. To illustrate, Wohlstetter and Odden (1992, p. 532) conclude, following a review of several research projects, that "in sum, even where decision-making authority appears to have been delegated, the degree of real authority given to the site is often remarkably limited”. In addition, a study by Meuret and Scheerens (in Leithwood and Menzies, 1998, p. 325) based on decisions at school level in public school systems in 14 countries, show that percentage of decision making approximate proportions to illustrate: "Ireland and New Zealand, greater than 70\%; Sweden, 48\%; Austria, Denmark, Finland, and Portugal, 38\% to 41\%; Belgium, France, Germany, Norway, Spain, and United States, $25 \%$ to 33\%; and Switzerland, 10\%.” One of the explanations for this situation comes from Wohlstetter and Odden (1992), who suggest that where a district sees the school as its subordinate then that makes any authority relationship difficult to change. The implementation of decentralization in the form of SBM "appeared to be strongly influenced by districts politics". This is in fact not surprising, because the nature of the public school system is one of resistance to even minimal change, even with a decentralised policy.

\subsubsection{Site council and SBM models}

Murphy and Beck (1998, p. 14) noted that a "central feature of SBM is the site council”. While site councils vary in composition and responsibilities, most writers agree that it is within a site council that school stakeholders such as principals, teachers, parents, community members and students do participate in decision making.

The site council is a form of community involvement in school governance, based on regulation, with elected but voluntary membership. Certainly the intention 
behind site councils is to implement democratic participatory decision making. Rose (2003) differentiates community participation in schools as ranging from genuine participation to pseudo-participation. Rose (2003, p. 47) writes that:

genuine participation, implying the ability to take part in real decision making and governance, where all members have equal power to determine the outcome of decision and share in a joint activity...'pseudo participation' is, at best a consultative process whereby citizens are merely kept informed of developments at the school level, and are expected to accept decisions that have already been made.

McGinn and Welsh (1999) illustrate participation as a series of steps. The lower steps refer to exercising authority about building maintenance, then authority relating to budgets, then transferred authority to make budgets (which involves hiring and firing personnel). The final step relates to authority over curriculum decision making.

A study by Rentoul and Rosanowski (2000) offers a useful map of the site council continuum from advisory role to governing role (from informing, to influencing, co-determining and finally determining). Shown as Figure 3.1 the conceptual map of the site council is modelled on the experiences of countries such as New Zealand, Australia, Canada, the United States and several in Europe. One example, in the beginning of SBM implementation in Alberta, Canada, there were no site councils (Caldwell, 1994), but then in the 1990s site councils were established, although they generally played an advisory role to the principal.

A number of models have also emerged from empirical studies on school based management. Wohlstetter and Odden (1992), and Murphy and Beck (1995) propose three models, based on who has control over decision making: administrative control (the principal is dominant in terms of power and control), professional control (teachers are dominant), community control 
(parents/community members are dominant). Leithwood and Menzies (1998) propose a model they call balanced control, where parents and teachers are equally dominant.

Figure 3.1. The site council role map in several countries

\section{Optional}

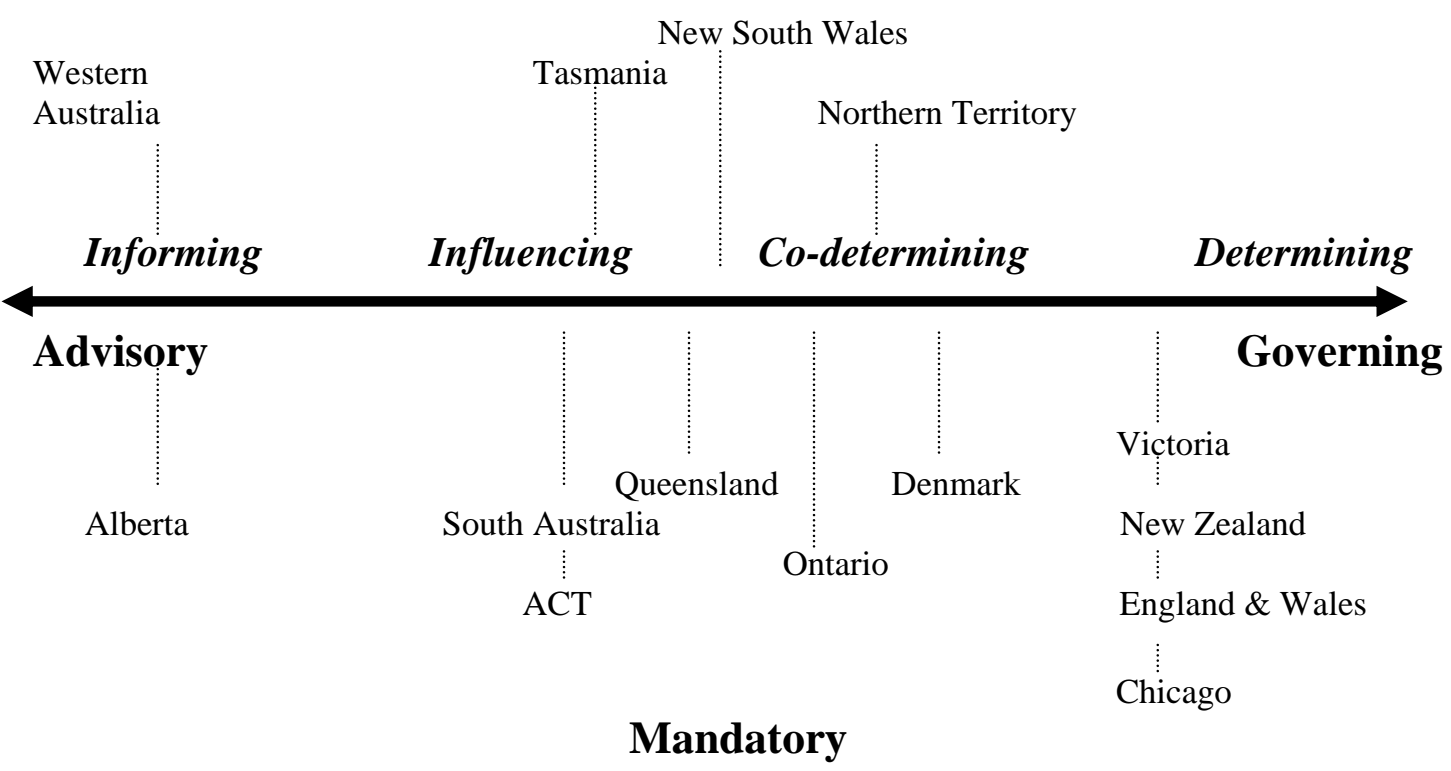

(adapted from Rentoul and Rosanowski, 2000, p. 36)

School based management modelled on administrative control strengthens the principal's role to be more accountable. In particular, the principal has to serve the students well with efficient use of school resources as these relate to the budget, personnel and curriculum. Edmonton district in Alberta, Canada is a good example of this model, which, according to its proponents, increases school responsiveness, accountability and effectiveness (Brown, 1990).

In the professional control model of SBM, the basic assumption is that teachers as professionals know better and they are the ones with the most relevant knowledge of students. In addition, it is argued that this model increases participation. Because teachers make their own decisions about school business, 
this model increases employee involvement, thereby improving efficiency, effectiveness and better results (Leithwood and Menzies, 1998). Wohlstetter and Odden (1992) noted that in Los Angeles, California, this model of SBM emerged because half of the composition of site councils was reserved for teachers and the council had discretion to make decisions.

A community controlled model of SBM exists when parents and community members are the majority on a site council. This model works well as governing body when its roles are clearly defined by regulations. This can lead to increased accountability to the community and greater costumer satisfaction. As its name implies, in this model it is community people not professional in schools who are in control. The model promotes the preferences and values of parents in terms of what they think are best for their children. McGinn and Welsh (1999, p. 32) argue that this model "signals a loss of public confidence in professional expertise”. Since 1989, New Zealand's education reform has adopted this model of SBM. For secondary schools, SBM extended the existing roles of its governing body, but for primary schools SBM was a really significant change (Wylie, 1995). Boards of trustees in New Zealand, the name given to the site council, have five elected parent representatives, one teacher representative (elected), the principal and one student for high schools, as stipulated by the Education Act (Wylie, 1995). Somewhat similarly, in Chicago, USA, the majority of the local school council should be 6 parents and 2 community representatives, out of total 11-12 members (Leithwood and Menzies, 1998).

The balance control model is intended "to make better use of teachers' knowledge for key decision making in the school, as well as to be more accountable to parents and the local community” (Leithwood and Menzies, 1998, p. 331). Both 
parents and teachers have equal numbers on the site council, with decision making powers regarding the budget, personnel and curriculum. This model requires that parents and the local community act as partners with the school. The model also calls teachers to be responsive to the values of the communities in which schools reside.

One negative aspect of site councils, Bray (2003, p. 37) suggests, is that they “in many cases lack expertise and understanding of their responsibilities”. Bray argues that this is because members are volunteers. Furthermore, in developing countries, site councils are generally made up of people who mainly come from elite sections of the community, do not always have concerns for disadvantaged groups, and sometimes take school resources for their own purposes (Bray, 2003).

\subsubsection{Strategies to make SBM successful}

In his thorough research on the impact of school based management particularly on learning outcomes in four countries, namely the United States, Britain, China (Hong Kong) and Australia, Caldwell (1998) describes an interesting result. In Hong Kong, what emerged about SBM relate to student learning issue was a "rich conceptualisation and sophisticated analysis" (p. 6); which in Australia, according to Caldwell, this is not particularly measured. Meanwhile in America and Britain, what much of the research reports show is not encouraging in terms of student learning. As Leithwood and Menzies (1998, p. 340) illustrate, “... [the] little research based evidence that does exist suggest that the effects on students are just as likely to be negative as positive. There is an awesome gap between the rhetoric and the reality of SBM's contribution to student growth...”. Empirical studies mainly in the United States, reviewed by Fullan and Watson (2000), compared schools that adopted SBM policy with schools which actually practiced it. The 
authors concluded that "SBM is an amorphous umbrella concept which is treated as an end in itself” (p. 455). Similar findings were also identified in Britain resulting from the implementation of local management schools (see Whittey and Power, 1997).

Unlike the above explanations, several writers (Caldwell, 1998; Leithwood and Menzies, 1998; Fullan and Watson, 2000) argue that when related to student learning, the analysis should move beyond school based management issues. As Caldwell (p. 17) puts it:

[t]he explanatory model is confirmation of what research elsewhere has shown, namely, that decentralisation of decisionmaking in planning and resource allocation does not, of and in itself, result in improved learning for students. There is no direct cause-and-effect link between the two. What the model does suggest, however, is that if the linkages are made in an appropriate way, then an indirect effect is realised through action in the personnel and professional domain and also in the curriculum domain.

Fullan and Watson (2000) argue that in order to make improvements in schools happen the conditions which enable changes to be made must not taken for granted. The authors offer what they describe as collaborative culture or professional learning communities as important pre-conditions. Based on Newman and Wehlage's research, Fullan and Watson (2000, p. 456) point out that successful schools have teachers and principals who “(1) formed a professional learning community, that (2) focussed on student work (assessment), and (3) change their instructional practice (pedagogy and support for learning in the classroom) accordingly in order to get better results.” This is somewhat similar to what Caldwell (1998) and Leithwood and Menzies (1998) propose to improve student learning called with backward mapping from Elmore's idea (Figure 3.2). The proposed concepts show that any kind of reform has firstly to put emphasis on 
school core business: teaching and learning. Then, what really happens in school should be communicated to parents and communities to engage them in terms of caring for students and playing a more active role with regard to it (Fullan and Watson, 2000).

Figure 3.2. Backward mapping from student outcomes: an illustration

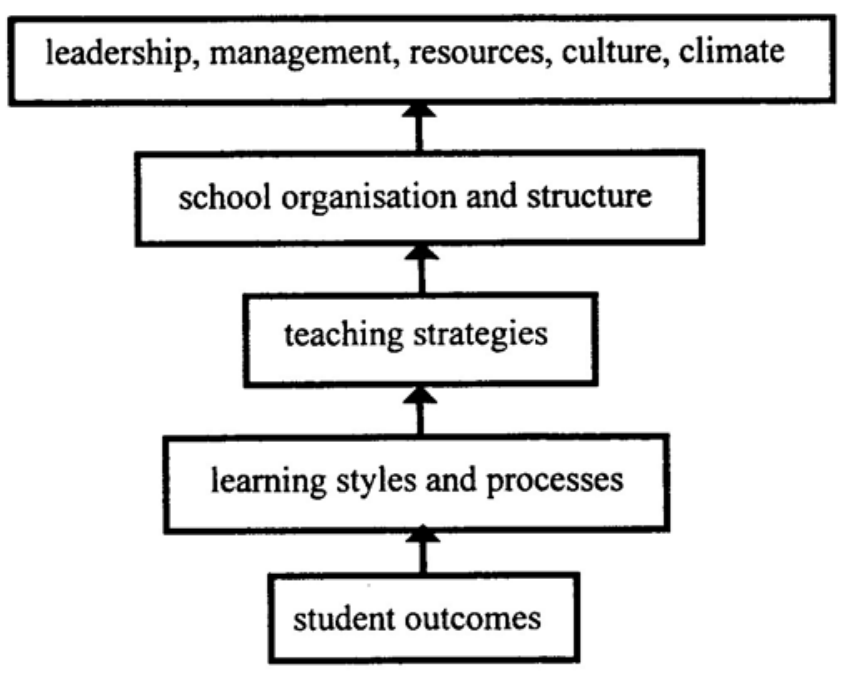

(source: Caldwell, 1998, p. 30)

Furthermore, because SBM is a kind of decentralisation of authority from a superior body, which may be a district office, some roles might be significant in order to make good effect. Bryk et al., (1998) study about SBM practice in Chicago argue that there are four elements that districts can play as external school bodies supporting schools: maintain decentralization, provide for local capacity building, establish rigorous external accountability, and stimulate access to innovation.

The district office has to play a part in maintaining decentralization. On the issue of capacity building, Fullan and Watson (2000, p. 459) write that "here the investment is in policies, training, professional development, ongoing support, etc., in order to develop the capacity of schools and communities to pursue and sustain improvement at the local level within a national context of policies”. 


\subsection{Conclusion}

This chapter has shown that decentralisation is complex in its conceptualisation, design and implementation. In terms of public education, issues of power and authority have become salient in definition and interpretation. The reasons for moving to a decentralisation mode varies, and in Indonesia what has happened locally cannot be divorced from a consideration of the international discourse. As shown in the previous chapter, it was in fact, donor agencies that initially suggested educational decentralisation for Indonesia.

As varied as the decentralisation concepts, school based management is also varied and complex. However, there is some consensus, such as devolved authority to the school level and the establishment of site councils or similar local bodies. It is apparent that when policy makers choose a particular model, this often reflects their interests and hopes for changes to the school system. As outlined, an SBM policy needs consistent support from the central and district levels, and capability preparation at the local level if it is to be a successful governance model.

In the next chapter, the research methodology is discussed. 


\section{Chapter 4}

\section{METHODOLOGY}

\subsection{Introduction}

The previous chapters have discussed Indonesian education and the literature review discussed aspects relating to school based management. This chapter discusses the methodology used to examine SBM initiatives in a region in Indonesia. In order to identify and analyse the policy and practices of school based management in Indonesian secondary schools this research used qualitative inquiry. With specific reference to the Municipal city of Mataram in Lombok, West Nusa Tenggara province, the researcher used a case study approach.

Several methods of collecting data and analysing it were undertaken. Document analysis of national, district and school level materials was undertaken. Questionnaires were given to school stakeholders. Interviews were carried out at district and school levels.

\subsection{Research orientation and methods}

According to Cumming (1994) nearly all research projects in educational settings can be grouped into three categories of orientation: descriptive, interpretive and ideological. The orientation of research is a philosophical basis where the researcher identifies the project; formulates research problems and chooses his/her approach to that with a specific theory and methods. The research orientation of this study is interpretive. 
With this particular orientation, the researcher's job was “attempting to make sense of, or interpret, phenomena in terms of meanings people bring to them” (Denzin \& Lincoln, 1998, p. 3). Further, as Patton (2002, p. 39) argues, the interpretive study "takes place in real world settings and the researcher does not attempt to manipulate the phenomenon of interest”. The aim of this study was to interpret school based management (SBM) phenomena at state secondary schools in Indonesia, together with a specific case study located in Mataram, Lombok. In order to achieve that, the study had to include an analysis of the national policies that established SBM. The study examined the context of the policies within their public institutional settings. In addition, the opinions and expectations of district and school level stakeholders were sought, to identify the realities of the situations where SBM was actually implemented.

Schwandt (2000, p. 193) writes that in an interpretive study "it is possible to understand the subjective meaning of action (grasping the actor's beliefs, desires, and so on) yet to do so in an objective manner”. However the biases, values and judgement of the researcher cannot be denied and as a result a researcher has to state matters explicitly (Creswell, 1994). In an interpretive study, both the researcher and participants roles are undoubtedly prominent. This is particularly so when the researcher has acquired an insider status with the participants and then tries to interpret their experience (Schwandt, 2000). Therefore, the researcher acknowledges that while this study was conducted with theoretical rigour and standard data analysis procedures, it is still his interpretation of data that was collected from various sources and in various forms. Moreover, the researcher also had a personal motivation to improve 
Indonesian SBM, and it is possible that this may have unknowingly been allowed to influence his interpretations of the data to some extent.

A case study approach was used in this study because it fits with the characteristic of interpretive inquiry (Anderson, 1998). Denzin and Lincoln (1998, p. 3), for instance, point out that "qualitative research is multi methods in focus, involving an interpretive, naturalistic to its subject matter”. This approach also leads to a better understanding of the phenomena, through the use of diverse methods to collect data and by conducting the study in a relatively short period of time.

\subsection{Case study}

Cresswell (1998, p. 61) defines the case study as "an exploration of a 'bounded system' or a case (or multiple cases) over time through detailed, indepth data collection involving multiple sources of information rich in context”. The term 'bounded system' or a case relates to the context and scope within which the researcher locates the case to be studied. Usually it is up to the researcher to decide the circumstances of what is called "a case" in a case study (Cresswell, 1998). The case itself, however, can be more than one site - it depends on the researcher to establish his/her unit of analysis (Yin, 1994). School based management practices at state secondary schools in Mataram, Indonesia, is the phenomenon and the unit of analysis in this study. Although a study might take place on several sites, it can be counted as a single phenomenon. This fits with Stake's (2000, p. 437) clasification on the nature of the case which can be identified as a 'collective case study'. Moreover, Stakes (2000, p. 437) argues further as follows: 
Individual cases in the collection may or may not be known in advance to manifest some common characteristics. They may be similar or dissimilar, redundancy and variety each important. They are chosen because it is believed that understanding them will lead to better understanding, perhaps better theorising, about a still larger collection of cases.

A case study approach is also useful in terms of gathering data for analysis which can be both quantitative and qualitative (Yin, 1994; Stake, 2000). Based on arguments by several authors (Yin, 1994; Cresswell, 1998; Anderson, 1998) this research used several empirical data sources such as documentation, interviews and direct observations in addition to a questionnaire survey. These various sources of rich empirical data are then analysed as a methodological triangulation.

The study was concerned with understanding school based management in one location. As Yin (1994, p. 10) states, a case study research "does not represent a 'sample', and the investigator's goal is to expand and generalize theories (analytic generalization) and not to enumerate frequencies (statistical generalization)...the goal is to do a 'generalizing' and not a 'particularizing' analysis”. Again, the study will inform an evaluation about policy and practices related to state secondary school context in Indonesia, which can be used to guide decision-making and improve education for the future.

\subsubsection{Case study location}

The field research took place in the Municipal City (kota) of Mataram. Located in Lombok Island, east of Bali, Mataram is the capital city of West Nusa Tenggara Province which is located in the eastern part of Indonesia. The municipal is relatively small with a total area of 61,30 square kilometres and has a high population density of 5,261 per $\mathrm{km}^{2}$ (Soewartoyo, 2002:10). 
There are three sub-municipals (kecamatan) in Mataram: Ampenan, Mataram and Cakranegara. There were seven state general secondary schools (years 10-12) across Mataram at the time of the study. Two of them were less than 2 years old, and each sub-municipality has at least two secondary schools. This study investigated school based management policies at district level and school levels across all sub-municipalilties using questionnaires, interviews and site studies.

State secondary schooling across Indonesia is relatively similar in terms of infrastructure and staffing because of the standard provisions of the education system prior to the Reform era. All schools were managed centrally from the central office in Jakarta. So, in this study a degree of generalisation is possible with regard to Indonesian secondary schools generally

Permission to conduct the study was obtained from government agencies in Mataram. Through the Head of Mataram Regional Planning Development Board (Bappeda) and the Head of The Mataram National Education district office, courtesy letters with copies of the research proposal were sent seeking permission. These offices responded with recommendations and a permission letter. The researcher personally visited five out of seven state secondary schools in Mataram and questionnaires were distributed through each school principal. Copies of permission letters were also given to interview participants at school and district levels. 


\subsection{Data collection}

\subsubsection{Documentation}

According to Hodder (2000, p. 704) documents are important in qualitative research because "access can be easy and low cost, ... the information provided may differ from and may not available in spoken form, and ... texts endure and thus give historical insight”. Atkinson and Coffey (2004, p. 59) state that "documentary materials should be regarded as data in their own right. They often enshrine a distinctively documentary version of social reality. They have their own conventions that inform their production and circulation”. Similarly, Miller (1997) argues that "Texts are one aspect of sense-making activities through [which] we construct, sustain, contest and change our senses of social reality”. In short, official public documents are important to analyse because they mirror power relations and create reality in the society.

In this case study, public documents were one of the data sources used. Documents were important because SBM was a new concept in Indonesia, and documents provided the formal frameworks of SBM. The documents used in this research were regulations, policy statements, and guidelines.

A primary documentary data for this study was the Ministry of National Education decree number 044/U/2002 (MoNE, 2002). This decree established the Education Councils in each district and School Committees in each school. When the decree was released, it was intended to change the nature of the governance of schools from the systems of the previous era. The decree was based on the legislation about regional autonomy, Law 22/1999, which stipulated that education be devolved to the district level. Furthermore, Government regulation (PP 25/2000) also stipulated the specific functions of the central and 
provincial offices pertaining to educational services. To make the public more knowledgeable about the decree, the Ministry also distributed certain guideline materials. All of these documents are in the public domain and are available throughout government education offices, schools, or even on the internet.

In the middle of 2003, the Indonesian House of Representatives passed a new education law (Law 20/2003 titled the National Education System). From this law regulations pertaining to community participation in Education Councils and School Committees were promulgated. In addition, the government and the House also approved a new autonomy law in 2004. This was Law 32/2004 which replaced Law 22/1999. However, there is no substantial change in terms of educational decentralisation in the new autonomy law (Malik, 2005).

The other primary documentary data sources used in the study were the Mataram mayor's decrees about the education council and principals' decrees concerning school committees. These documents proved useful for analysing developments at district and school levels.

\subsubsection{Questionnaire}

A questionnaire survey was used in this study. An advantage of the questionnaire is that it can be used to gather data in a relatively short period of time. Moreover, it can gather straightforward and factual information from participants (Anderson, 1998). In this study, the questionnaire was used to collect information regarding participants knowledge, experiences and attitudes. The data was subjected to further analysis. There were three kinds of participants who were involved in the questionnaire survey: principals, teachers and school committee members. 
The questionnaire was first designed and written in English, then translated into Indonesian, so that all participants were able to understand it. The design of the questionnaire followed suggestions by Anderson (1998, p. 177) that “questions about age, gender...can be threatening and are generally best asked at the end rather than the beginning”. Also, in order to make participants interested and more at ease, the researcher used important 'warm-up questions' first.

Before the questionnaire was distributed, the researcher pilot tested it with several teachers. The intention here was to "identify ambiguities in the instruction...clarify the wording [of] question....and [be] alert to unanticipated answers” (Anderson, 1998, p.179). As a result, some changes were made to the questionnaire.

There were 21 questions divided into three sections. The first section, containing six questions, dealt with the sources of information about SBM, experiences with the SBM policy, perceptions about devolved authority to the schools under the SBM policy, and experience of being involved in SBM training were asked. The six questions in the first section covered the topics listed in Table 4.1.

Table 4.1. Focus of questionnaire in the first section

\begin{tabular}{|c|l|}
\hline Q1 & Sources of information about SBM \\
Q2 & Enough information about SBM policy \\
Q3 & Participation in SBM training \\
Q4 & Kinds of authority devolved to school \\
Q5 & Authority devolved in terms of budgeting \\
Q6 & Authority devolved in terms of staff \\
Q7 & Authority devolved in terms of curriculum \\
\hline
\end{tabular}


Table 4.2. Focus of questionnaire in the second section

\begin{tabular}{|c|l|}
\hline Q8 & Kinds of community participation in school \\
Q10 & Is SBM good for your school ? \\
Q11 & Good thing about SBM \\
Q12 & Impact of SBM at school \\
Q13 & Change of workload because of SBM \\
\hline
\end{tabular}

Table 4.3. Questionnaire, Section 2, Q9

\begin{tabular}{|c|l|}
\hline A & School committee is an independent body \\
B & School committee members appointed by principal \\
C & Role of school committee compared to BP3 \\
D & Approval school budget is needed from school committee \\
E & School committee has right to supervise school \\
\hline
\end{tabular}

Table 4.4. Questionnaire, Section 2, Q14

\begin{tabular}{|c|l|}
\hline A & SBM makes school management more open and effective \\
B & SBM pursues democratic decisions in school \\
C & SBM involves community in school decision making \\
D & SBM enhances school and community relationship \\
E & SBM improves effective teaching-learning in school \\
F & SBM improves student learning \\
G & SBM gives teacher more freedom \\
\hline
\end{tabular}

In the second section, seven questions asked about participants' perceptions, knowledge and experiences regarding parents/community participation, and school committee and its impact on participants and school (Table 4.2). Question nine (Q9) gathered opinions regarding the school committee and is summarised in Table 4.3 with the answer being 'Yes, No or Don't Know'. The last question in this section (Q14) asked about participants' 
attitudes toward SBM (Agree, Not Sure and Disagree) as shown in Table 4.4. In Q10, Q11 and Q 13 spaces for additional comment were supplied.

In the last section, eight questions dealing with basic issues such as gender, age group, and education background. However there were slightly different questions for each groups of participants. For teachers, the questionnaire asked about their teaching experiences, subjects, class taught and job position. Principals were asked about their length of time in the position and how long at their present school. School committee members were asked about their involvement in BP3, how long they had been committee members and which groups they represented. Table 4.5 summarised the last section of the questionnaire.

Table 4.5. Focus of questionnaire in the third section

\begin{tabular}{|c|c|}
\hline 1 & Sex \\
\hline 2 & Age \\
\hline 3 & $\begin{array}{l}\text { Principal: total years as principal } \\
\text { Teachers: total years teaching } \\
\text { Committee: members of BP3 previously }\end{array}$ \\
\hline 4 & $\begin{array}{l}\text { Principal: years in the present school as principal } \\
\text { Teacher: teaching in what curriculum area } \\
\text { Committee: how long has been as committee member }\end{array}$ \\
\hline 5 & Highest education qualification \\
\hline 7 & $\begin{array}{l}\text { Teacher: what class do you teach } \\
\text { Committee: which representative group do you represent }\end{array}$ \\
\hline 8 & Teacher: job position in the school \\
\hline
\end{tabular}

The questionnaires were distributed by the principals to all general state secondary schools in Mataram who already had graduated students (5 out of 7). Then the principals distributed teachers' questionnaire to the available teachers in the schools. Some principals allocated school committee's questionnaires, 
while others just gave addresses to the researcher to initiate contact. Questionnaires for principals were completed by themselves. The distribution was as follows: One questionnaire for each principal (100\% returned); 15 questionnaires for teachers in each school (76\% returned); and 7 questionnaires for school committee members in every school (60\% returned). They were relatively good return rates and in some measures they represented state secondary school stakeholders in Mataram well (Table 4.6)

Table 4.6. Distribution of returned questionnaire

\begin{tabular}{|c|c|c|c|c|c|c|}
\hline Schools & SMAN 1 & SMAN 2 & SMAN 3 & SMAN 4 & SMAN 5 & Total \\
\hline Principal & 1 & 1 & 1 & 1 & 1 & 5 \\
\hline Teachers & 10 & 13 & 9 & 14 & 11 & 57 \\
\hline Committee & 4 & 6 & 3 & 2 & 6 & 21 \\
\hline
\end{tabular}

\subsubsection{Interviews}

As a data collection method, the interview is most commonly used in qualitative research (Creswell, 1998). Anderson (1998, p. 100) writes that an interview is a "specialized form of communication between people for a specific purpose associated with some agreed subject matter”. However, as Fontana and Frey (2000) explain, interviews can take many forms and have various uses. This study used a key informant interview type (Anderson, 1998) where verbal interchange between researcher and participant occurred.

The interview was conducted after the researcher had collected the completed questionnaires from participants. The interview helped to elaborate on some issues which arose from the questionnaires and also for checking and 
triangulation of data. The participants for the interview were differentiated into two groups: district and school levels. At the district level, interviews involved key persons who had a stake in education in Mataram and included education district officials, members of district parliament in an education portfolio, supervisors, members of the education council and teacher unions. At the school level, the interview participants were principals, teachers and school committee members. Table 4.7 summarises the number and types of participants in interview sessions.

Table 4.7. Interview Sessions

\begin{tabular}{|l|c|l|c|}
\hline \multicolumn{2}{|c|}{ District level } & \multicolumn{2}{c|}{ School level } \\
\cline { 1 - 2 } Education official & 1 & Principal & 4 \\
\hline Member of parlianment & 1 & Teacher & 6 \\
\hline Supervisor & 2 & School Committee & 4 \\
\cline { 1 - 2 } Education Council & 3 & & \\
\cline { 1 - 2 } Teacher unions major & 1 & & 14 \\
\cline { 1 - 2 } $\begin{array}{l}\text { Official from } \\
\text { office }\end{array}$ & 10 & Total & \\
\hline Total & & & \\
\hline
\end{tabular}

The interview process was standard. First, the researcher asked each participant to agree to be interviewed. Second, a place for the interview was located and then the participants were shown the recommendation and permission letters from the district government. Most of the participants preferred to be interviewed in their homes, which probably made them feel more relaxed, secure and informal. Each time, the intention of the interview was 
explained, and a consent form was provided for them to sign, if they agreed. Consistently, all agreed to participate and to share their thinking. All interviews were audio-tape recorded.

To guide the interview, the researcher provided an outline of the ten questions to be asked of the respondents. This was intended to keep the interview sessions on track. The focus of the questions was to gather as much information as possible regarding school based management policies and practices in state secondary schools in Mataram. Accordingly, this interview was an elaboration of issues that were already considered in the questionnaires. The interview questions are shown in Appendix 2.

Question 1 of the interview guide was designed to gather knowledge and experience regarding school based management. Question 2 sought the participants' opinions regarding what specific areas can be devolved to schools. The concern is with participants' aspirations and what power issues they thought most important. Question 3 was designed to explore quality issues facing Indonesia's education system. Question 4 related to the role changes that occurred in the education district office since the introduction of SBM.

Questions 5 and 6 focused on community involvements that become central to SBM. Question 7 was particularly designed to ask respondents at school level about their experiences of implementing the ministry decree. Question 8 sought participants' opinion and attitudes regarding the school committee. For instance, did they think it was a sufficient and fair arrangement? The last two questions asked respondents about their experiences and reflections on how SBM might be improved. 


\subsubsection{Site Studies}

A triangulation of data was also obtained via site studies. Two out of the five state secondary schools which became the sample of this study were chosen from different sub-municipal (kecamatan). The site studies were conducted in the last month of the fieldwork research (January 2004). The schools were allocated two weeks each for data collection to occur on site.

At each school, the researcher met with the school principal to ask permission and to explain the intention of the site studies. Both principals agreed to participate. The site studies included observations during school meetings, and informal talks with the principals, teachers and school committee members. Because school committee members were rarely found in the school, the researcher went to their homes to gather data.

\subsection{Data Analysis procedures}

\subsubsection{Preparing the data for analysis}

Primary data for the document analyses were public documents, some of which were already in English while others were translated to English from Indonesian. Questionnaire data were tabulated in order to make it easy to analyse. Additional comments by respondents were translated into English. The audio-recorded data from interviews were transcribed (in Indonesian), and were translated into English. As a process, the researcher first analyzed the documents, followed by regulations about SBM, and then fieldwork notes.

\subsubsection{Regulation at national level}

The analysis and discussion about regulations at national level pertained to the Ministry of National Education decree number 044/U/2002. This included 
analysis of the reasons for and the preamble of the decree. The content of the policy and its explanations in the decree appendixes, guidelines and other publications from the central office were critically examined. To put the policy in perspective, the researcher used data from the literature review in the analysis, particularly to answer the first two research questions.

\subsubsection{Field data}

Data from the fieldwork was divided into district and school levels. Data gathered from the district level, including regulations, transcripts of interviews with stakeholders at district level (members of parliament, education district officers, education council members, teacher union representative, and supervisors) were analysed. At the school level the analysis included examining the decree that stipulated school committee arrangements, and returned questionnaires and transcripts of interviews with stakeholders at the school level (principals, teachers, and school committee members). Methods of document analyses that were used at the national level were also used at the district and school levels.

Interview data from both levels was transcribed. It was then loaded onto NVivo (a computer program for qualitative data analysis). In order to identify and contextualise comments in the discussion, coding was used in the Nvivo (called document attribute) programme to show levels (either district or school), respondent's position (district official, supervisor, member of parliament, unions, education council member, principal, teacher, or school committee), sex, ethnicity (Sasak [native people of Lombok], Javanese, Balinese or Bima), and sequence number of interview respondents. 
Data obtained from the questionnaire wase tabulated using Microsoft Excel. Several respondents gave additional comments in the questionnaire to explain and emphasise their answers. The comments were then transcribed and loaded into NVivo using coding as for the interviews. To differentiate these from the interview data, the researcher used code 'Q' for questionnaire and 'I' for interview followed with a dash and number. So, a code of Q-35 means a questionnaire’s response from respondent number 35 on my list.

The analysis and discussion in Chapter 6 shows the realities and complexities about school based management in state secondary school from the stakeholders' perspectives at district level. Document and interview analyses were the main sources for this chapter. For chapter 7, the researcher brought together document analyses, questionnaire and interview data to illustrate school based management at the school level from stakeholders' views and practices. Site studies observation in two schools generally confirmed what stakeholders had commented and answered in the interview.

\subsection{Trustworthiness}

In a qualitative study Lincoln and Guba (Cresswell, 1998, p. 197) maintains that to establish trustworthiness, the research has to be credible, transferable, dependable and confirmable. These terms imply validity and reliability. Validity means that the researcher actually investigates something that matches what is being looked for, and this is research interpretability (internal validity) and research generalisability (external validity) on applicability to a larger population. On the other hand, reliability of the research deals with consistency of research results, which include consistency in terms of collection, analysis and interpretation of data (internal reliability and possibility) 
to gain the same results if research procedures are conducted in other contexts (external reliability)

In order to achieve trustworthiness, the present research used a triangulation procedure in terms of methods of data collection and its analysis. The triangulation method was used by the researcher with showed the transcript of interviews to some respondents before data analysis for checking and additional comments. In addition, the triangulation method was also used for site studies and document analysis to provide a necessary context for the policy investigation and impact assessments in the location of the case study.

\subsection{Ethical issues}

In order to protect the individuals who participated in this study, appropriate ethical requirements were followed. In this way the research participants could be assured of their privacy, anonymity and the confidentiality of their responses. It was pointed out to them that data which was collected from fieldwork was placed in a safe and secure location at all times. The study addressed these ethical issues and followed the standard procedures of the ethical sub-committee of the Faculty of Education, Victoria University of Wellington, New Zealand.

\subsection{Conclusion}

This chapter discussed the methodological aspects of the study. A framework was presented, followed by a discussion on the case study. Descriptions of data collection, analysis and management were given. The chapter ended with a discussion on trustworthiness and ethics. In chapter 5 , the documents analyses of SBM regulations will be discussed. 


\section{Chapter 5}

\section{POLICY AT THE NATIONAL LEVEL}

\subsection{Introduction}

The implementation of school based management policy is to support school autonomy in order to increase education quality in accordance to national and international standards (Fajar, 2004).

The excerpt above of a speech by A. Malik Fajar, the Minister of National Education, on the National Education Day (2 May 2004) demonstrates the view that school based management policy is a panacea to improve educational quality. Such a perspective created high expectations right from the beginning when SBM was considered, until it became official policy. This could provide us with an indication to expect whether what is proposed by the Minister is inevitable or just another rhetoric for political convenience.

This chapter analyses the Minister of National Education of the Republic of Indonesia’s decree (Kepmendiknas) number 044/U/2002, which was stipulated as the legal basis for implementation of school based management. The analysis focuses on several aspects of the decree, such as the main content (the body of regulation), the elucidation and the related official materials that served as the guidelines for the decree's implementation.

The focus of the decree was the establishment of new 'governing bodies' at the district and school levels. This chapter therefore analyses the establishment of the 'education council' and 'school committee', as the two new institutions: what they are, how they were established, what their roles, functions and authorities are, and the potential effects of their establishment on education stake 
holders. Related documents regarding this will also be analysed because they formed the bases for the rationale and conceptualisations of SBM as envisaged in the decree.

All of the documents are analysed in two ways. First, data from the literature reviews was used to explain and understand the decree from a wider perspective. Where consensus was found in the literature, it is used to examine certain issues in the decree. Second, the decree's formulation, wording and elucidation are reviewed and critically analysed in an attempt to identify the exact meanings, contexts and intentions of the designer and writer on various issues such as power relations, transfer of authority, institutional composition and arrangements.

\subsection{The Decree}

In this section, the decree's origins, including background and rationale for enactment, are analysed. This covers the main contents, appendices and other related materials. All the materials used include documents published by the Ministry of National Education (MoNE) in Jakarta and other materials regarded as public documents, available from various sources in various forms. The copy of the decree is readily available and can be found in schools or district offices in printed form, and is is also available in electronic format (soft copy format) from the MoNE's website.

\subsubsection{Origin of the decree}

The Kepmendiknas 044/U/2002 was one of the most awaited decrees in the history of Indonesia's education. Officially the decree was released on 2 April 2002, signed by A. Malik Fajar, the then Minister of National Education 
(MoNE, 2002). The history of the decree, however, can be traced back nearly three and a half years previously, when the World Bank published a report about the performance of Indonesia's education (see section 2.3.5 under sub-heading School Based Management). The possibility of greater school autonomy was further explored by the government which formed several task forces following the World Bank report.

Upon publication of the Task Forces’ progress report in early July 2000, the public perception was positive. It appeared that the general public had welcomed and supported the idea of school based management (Kompas, 2000a). In their final report, the Task Forces wrote explicitly about the school based management implementation (Jalal and Mustafa, 2001, p. 126), as follows:

\begin{abstract}
laws and regulations need to be prepared to support the idea of school decentralization in the form of school-based management. Currently, Laws No. 22/1999 and Law 25/2000 only support the general idea of decentralization from central to local government. Furthermore, government regulation (PP) No. 25/2000 does not clearly specify the government role in public school management. To guarantee the application of school decentralization that promotes the quality education, it is necessary to describe the complete strategy of school decentralization in other forms of legal documents.
\end{abstract}

From then on, the Task Forces recommendations became the blue print for Indonesia's educational reform after the political reform in 1998, having formed the major part of Law no. 25/2000 concerning the National Development Programme in the section on educational development for the autonomy era (Rizali, 2004, personal communication). That law explicitly mentioned that the policy of regional autonomy at district level required the establishment of an education council and at school level a school committee. Both institutions were to operate as governance entities at both levels (Tim Pengembangan, 2000). 
The first public pressure on the MoNE to design a decree came just two months after a progress report seminar by the Task Forces. It happened when delegates of the Indonesian National Convention on Education asked Yahya Muhaimin, the Minister at that time, to implement school based management and to release regulations regarding such a change (Kompas, 2000c). The Minister's positive response invited further pressure and interest from the press (see for example Kompas, 2000e; 2000f;), education practitioners and experts, and also from individuals who were involved in a pilot project about school autonomy (see section 2.3.5 under sub-heading The Rintisan MBS).

Following the Minister's response, several high ranking officials of the MoNE began leaking information about the decree. Ace Suryadi as a head of the facilitation unit of the MoNE for Educational Decentralisation, for example, was reported as saying that a school based management decree cannot proceed without specific regulations to change patterns of school subsidy, budget, and control mechanisms (Kompas, 2000d). In another example, according to Indra Djati Sidi, the Director General of Primary and Secondary Education of the MoNE, a school can select and appoint its own principal and teachers (Kompas, 2001b). In a further example, Fasli Jalal, another high official at the MoNE, was reported as saying that schools would receive grants giving them flexibility to use the funds for their own purposes (Kompas, 2001a).

Explanations from several MoNE officials at this time indicated that the construction of school based management in Indonesia would be similar to SBM models from developed countries. This implied that a school was to be given authority over budgeting and personnel, and a bulk funding policy implemented These promises were obviously a significant policy leap from the previous 
practice of rigid centralism, and resulted in high expectations by the general public.

However the decree itself, as mandated by the Law 25/2000, was not signed for two years. Firstly, there was some concern as to why it took so long to become official policy when there was huge public support and some pilot project initiatives had proved relatively successful. This was because, in terms of regulation, the decree could be made effectively active only by the minister's approval and imposed without consultation with the legislative body or the general public. Secondly, all of the leaked information by high ranking officials was missing from the final decree's content. It could have been that debates and disagreement during the formulation of the decree could not be resolved. The policy makers realised how complex and sensitive the issues were, especially as some delegated authority in the educational sector had already been given to district government as a consequences of the autonomy law. It seems likely that the idea of school autonomy was too radical and there was considerable resistance and disbelief on the part of officials at the central office with regard to adopting school based management ideas within the Indonesian schooling system.

\subsubsection{Contents of the decree}

The preamble to the decree states that the reason for the regulation is to facilitate society's participation in education, and the decree is needed to create a new institutional structure. So the decree was intended to set up a new kind of organisation, and formed the legal basis for doing this. The contents of the decree are very short, consisting of only four articles as shown in Table 5.1 (MoNE, 2002; my translation). 
Table 5.1. Contents of the MoNE decree number 044/U/2002

\section{Article 1}

(1) In each district is formed an Education Council, as an initiative from the society and/or the district government.

(2) In each education institution or group of education institutions is formed a School Committee as an initiative from the society, educational institution and/or the district government.

Article 2

The formation of the Education Council and School Committee are to use the guide line for formation of Education Council and School Committee as attached in the Appendix I and II of this decree.

\section{Article 3}

With effect of this decree, then the decree of Ministry of Education and Culture No 0293/U/1993 of 1993 regarding the formation of Board of Education Assistance is abolished.

Article 4

This decree is effective on the date stipulated.

The first article deals with the formation of a new organisation in every district $^{1}$ and educational institution. The second article gives suggestions about how to form those organisations. The third article mentions stipulations about a specific decree in the past which is no longer valid. The last article outlines when the decree is to come into force.

In paragraph (1) of Article 1, there are two aspects which are mentioned explicitly: the creation of the new organisation at district level, and who can establish it. For the former, there is no other explanation available about this new institution, its functions, tasks, role, and authority, even who the client of the education council is. The only clear aspect is the name of the organisation. Although in the next section, there is mention of the guidelines that can be used

\footnotetext{
${ }^{1}$ The Indonesian word for district can mean either kabupaten or kota. In simple terms, kabupaten means an autonomous administrative government area where more than $50 \%$ of their population lives in rural areas and work as farmers; kota means municipality where more than $50 \%$ of the people work in service sectors.
} 
to form the organisation, the details are not stated explicitly in the body of the decree. This can be taken to mean that there are no clear legal consequences for the parties who are involved.

For the latter part of paragraph (1), the decree states that a new organisation has to be formed. However, it does not specify who is responsible for establishing the organisation. It could be either by the district government or by the society, and also possibly by both of them. This latter situation can occur in a district that has more than one education council, and can result in a problem of legitimacy. In addition the term society, as used, is also problematic, because its meaning is legally unclear. The decree does not give specific and clear meanings about who can be involved to constitute the new body. Without that, the formulation of responsibilities can lead to tensions between society and the district government. On one hand the new organisation may want to facilitate societal participation in education, but on the other hand the district government has a legal right to be involved and to steer the change process.

Regarding paragraph (2) of the article 1, there may also be a legal complexity here. Firstly, by using the term "educational institution”, the decree is imposing a uniform model of a new organisation. Regardless of their status, either state or private schools, or schooling levels have to establish a school committee. Later, appearing in the decree’s appendix, the obligation to establish a new organisation also extends to pre-school education (kindergarten), out-ofschool education, and even to institutions in the Islamic schooling system, either public or private Islamic schools. This kind of one-size-fits-all policy is remarkable, because denying school status in the reality of diverse situations shows that the designers did not have empathy with the complexities and may 
not have given careful enough thought to institutional arrangements. It seems the decree wants to swallow all kinds of societal participation at the school level in a monolithic form of institution. In this respect, the decree is crossing into the spheres of other ministry interventions (particularly the Ministry of Religious Affairs, which controls and manages the Islamic school system). This is unusual because the decree is the lowest regulation that can be promulgated by the central government, yet it has been portrayed as having far-reaching implications.

In other countries, like New Zealand (Wyle, 1995) or Australia (AbuDuhou, 1999), structural change in school organisations can only take place in public schools where the government supports these institutions with public funds. Private schools in Indonesia are minimally supported by the government (see for example Bangay, 2005), but the decree does not acknowledge this differentiation between private and public schools.

Furthermore, in terms of who has responsibility to establish a school committee, paragraph 2 of the decree is problematic. For instance, three parties have a right to constitute the school committee. It could be formed by the society, the educational institution or the district government respectively. Furthermore, establishing a committee can also be achieved through a combination of two or more parties of the three parties cooperating together. Obviously, it opens up the possibility of a competition that can lead also to a legitimacy problem, when more than one school committee is formed in one school. The consequences can be confusing, as when, for example, a district government introduces a decree which imposes a school committee for every private school at secondary level. The private school cannot refuse the school 
committee regulation imposed on it because the district government has the capacity and legitimacy to implement the decree.

In Article 2 another peculiar aspect is also evident. It mentions that when a party wants to establish an education council and school committee it can refer to the decree's appendices. The term "can be used" ${ }^{2}$ in the article shows that this decree is a "hesitant regulation". This means that each party does not have any obligation to follow this decree and its appendices, therefore they can establish the new organisation in their own ways. So while it is probable that one party might establish a school committee with clear, detailed and appropriate processes, it is also possible that a party with power can establish a committee for its own purposes.

The wording of the second article exposes the real political will of the central government for the SBM implementation. It seems that the policy makers in the central office do not fully support the ideas of school autonomy and local educational governance. The central office documents implicitly acknowledge that the decree can be bypassed if district or school stakeholders intend not to comply. The decree itself therefore states an explicit loop hole which could be used by those with reservations about SBM.

However, the last two articles in the decree have clearer meanings and are more straightforward. No other interpretations will follow regarding the legal base of BP3 (board of educational assistance) in each school, which, under article 3, has to be abolished. The intention to explicitly put an end to the BP3 regulation is to ensure that only one organisation is to facilitate societal

\footnotetext{
2 Translated from Indonesian's “bisa digunakan”, which means voluntary to be used if one thinks it is useful.
} 
participation at the school level, and this organisation is the school committee. In this way, any unwanted competitions or conflicts between the school committee and the BP3 are eliminated. This change also signalled that the rules of the game have also changed and that practices under the BP3 are no longer accepted.

In general, the first two articles which are the important parts of the decree, are ambiguous. They do not have clear meanings and their underlying rationale has not been explained, thereby creating potential confusion due to possible multiple interpretations during implementation. This lack of clarity is a serious weakness.

The decree reflects the inability of the central government, in particular the MoNE, to position the education sector in the right place, within the context of the autonomy law (Law 22/99). The changes also demanded that the central office changed its role from being an implementer of policy to being a regulator. In the autonomy era, the central office does not have any experience or clear ideas regarding these changes (Malik, 2004; World Bank, 2004).

\subsubsection{The decree's appendices}

In contrast to the content of the decree, which is brief, the appendices are much more detailed regarding the education council and the school committee. As stated in the previous section, such a situation has led to the assumption that the policy makers themselves are uncertain about the new organisations that have to be established in every district and school around the country. Other interpretations are possible. For instance, it may be that the MoNE does not want to impose a regulation which may intervene with district authorities. At the same time, by introducing the decree, a degree of technical and legal guidance is provided to school and district governments which do not have the capacity to 
formulate such regulations. Again, it must be stated that according to Article 2, the provisions of the appendices are not compulsory for education authorities.

There are two appendices that accompany the decree. The first outlines guidelines for establishing education councils and the second guidelines for starting school committees. While the appendices relate to organisations at different levels (district and school) and for different purposes, both are remarkably similar in structure and content. Both appendices have eight subsections: (I) definition, name and scope; (II) positions and characteristics; (III) aims; (IV) roles and functions; (V) organisation; (VI) formation; (VII) arrangement inter-organisation; and (VIII) closing. The contents of the appendices of this decree are shown in Appendix 3. In the following sections, the appendices are further analysed.

\section{Education Council}

The first section of appendix I defines the Education Council as "a body which provides a place for societal participation in order to improve quality, equity and efficiency of educational management in a district”. The phrase "provides a place" implies that this new organisation is to create space and opportunity for members of the public to participate particularly in educational matters. Further, it is also expected that any contributions should be useful and should lead to educational excellence. It appears that the education council is expected to have a direct role in improving quality when this is a primary task for the government itself. This means there is a hidden agenda embedded in the formulation of the decree, which is to make the general public take some responsibility for tasks that belong to the educational bureaucracy. 
From the third section on the aims of the Education Council, several things seem clear although also open to question. Firstly, the three stated objectives seem to merely serve to provide a greater clarity of definition for the education council. The document stipulates that educational quality can be reached when the council facilitates and channels societal aspirations and initiatives through policy and programmes. In relation to equity, the document states that the council can achieve this by "increasing responsibility and active participation from all layers of society in education implementation”. In relation to efficiency the document encourages, "creating ambience and condition for transparency, accountable, and democratic”. On the one hand, the document seems to state objectives that encourage education councils to undertake certain tasks, but on the other hand the policy is not responsive to public needs and dynamics because agendas from elements of the society are not included or are not easily facilitated.

Secondly, critical analysis of the objectives of Education Councils, as stated in the third section is important to ascertain the extent of potential success for the new body. However, this is difficult because the objectives in the appendices are normatively written and difficult to operationalize and assess.

In the fourth section, roles and functions are outlined. Roles for the council include it being an advisory agency, supporting agency, controlling agency and mediator. Except for the supporting and controlling functions, the other roles are standard ones. However, in relation to the council's second role “as a supporting agency in terms of financial, thinking and labour in educational implementation”, this appears to miss the point for establishing education councils. This is because the supporting role referred to in the decree is not a role 
that is to be played by the council, but rather it is an executive's role (belongs to a district government). In other words, it seems that the decree has intended to swap government obligations relating to a core issue (education funding) to the Education Council. Further, if the council is to play a supporting role, without further legal guidelines on what this means, then it would seem that the decree is just to make Education Councils act as charities to fund educational activities in the district.

There seems to be a misfit between the espoused controlling agency role of the Education Council, "in terms of transparency and accountability of educational implementation and outcome," and the nature and location of this kind of organisation. This is because as shown in the listed functions of the council, none particularly gives the council the right 'to control or manage' educational implementation and outcome (World Bank, 2004, p. 9). Again, this is another ambiguous section of the decree which can result in tensions and possibly create confusion in the field.

The appendices stipulate that the education council conducts cooperative work with local government and parliament, and encourages parents' involvement to improve educational quality. The stipulations are, however, too broad and not sufficiently focused. According to Malik (2004) none of these tasks are clearly stated. Take the first function for instance, which states that an Education Council's role is to increase “society's attention and commitment for quality educational implementation". The terms "attention" and "commitment" are difficult as yardsticks, particularly when these relate to "quality educational implementation" which is a never ending process. Thus, in reality it is difficult to perform tasks such as those stipulated when the audience is society at large. It 
therefore seems that these functions are immeasurable, making it impossible to gauge the success or failure of the council.

A closer scrutiny of the council's list of roles and functions reveals that there is no mention of the authority. Without a clear authority, it is impossible for the council to make decisions and recommendations that are binding for interrelated institutions such as the local government and parliament.

The fifth section is titled organisation, which seems inconsistent with the decree. As stipulated, the council is to give input and advice, and made recommendation to the local government/parliament, but in reality members of the bureaucracy and local parliament can become members of the council, which can have up to 5 people. In addition, sub-section V.2.c points out explicitly that the "Chairman position is not to be held by local government and parliament Elements”. So, the functions stated above are impractical because the officers of the council are already part of the organisation (Purwono, 2003). When members' involvement does not allow them to become a chairman, it is a clear indication from the decree's designers that the council is to have members from the executive or legislative, as long as they are not officially steering the organisation.

The appendices on the forming of Educational Councils seem to favour the holders of power, which is the local government. The stipulations give authority to the local government to manage the selection process, and establish the decree that is to be signed by the head of district. In this way any opposition is silenced, while simultaneously ensuring that the council becomes subordinate to the bureaucracy. 
In the seventh section regarding inter-organisation arrangements, as shown in part B and C of the Appendix 3, the Education Council's relationships with other organisations at district level are presented. These diagrams are important because they show a clear vision of what is intended. It seems that the intention in creating Education Councils is to create a body for governance at the district level. However, the local parliament is already in existence. It would be clear if, in the structural arrangements, the clients for the Education Council are shown. As it stands now, it is unclear which institutions really are the clients of Education Councils. It is unclear if the client is the local parliament (legislative) or the local government (executive) (Malik, 2004). Having two clients to serve is problematic and can lead to confusion for the council itself. When the council's client is the legislative, then the council has to support the work of the local parliament, as a supervisory role. Such a role, as an advisory agency to the local parliament makes sense, unlike a relationship with the executive.

Both parts $\mathrm{B}$ and $\mathrm{C}$ of the appendices do not clearly positioned the relationship of the council that has to be taken and others at the district level. The relationship between the council and legislative offices is satisfactorily identified, but not with the executive. In parts B, the council deals with the head of district, the mayor; but in parts $\mathrm{C}$ it is suggested to district education office. In the local context, a relationship with government is not the same as with the head of a district education office. Consequently, if the education council is to work properly its relationships must be clearly stated.

In the closing section of the appendices, it stipulates that the council “can be regulated” by legislation. Again, the phrase 'can' implies that this is not mandatory and can be ignored. Moreover, to subject the council to regulation 
through legislation is inconsistent with educational management under SBM. This is because the council is part of governance and not management with the local government having full authority.

\section{School Committee}

As previously stated, the standard treatment given to the Education Council and the School Committee is not a coincidence. The decree's treatment for both institutions is similar in terms of structure, content and even wording. This is a "cut and paste" approach to drafting regulation and seems rather simplistic.

In the first paragraph of section one, the definition of School Committee is as follows (MoNE, 2002; cited from appendices II of the decree):

an autonomous body which provides a place for societal participation to increase quality, equity and efficiency of educational management in each educational institution which is involved in pre-school education, schooling system or out-ofschool education.

Similar to the definition of Education Councils, the one for School Committees also emphasizes several aspects of educational management at the school level. In addition, the decree appendix states that the School Committee is a required body to be established not only for schools but also for pre-schools and out-ofschool education institutions. This means that educational institutions at any level, in any system and of any status must establish a school committee. This requirement implies that when institutions establish a school committee, they can be regarded as practising school based management. The belief is that the school committee is autonomous and will facilitate community aspirations and practice transparency, accountability and democratic management. The decrees impresses 
on the public that the era of the BP3, where the focus has been on collecting funds from parents, is over.

However, in the third paragraph of first section, the decree stipulates that the BP3 which already exists in schools "can be widened in its functions, roles and membership according to these guidelines”. Again, this statement is inconsistent with what is stipulated in Article 3 of the decree where it is stated explicitly that the BP3 regulation in school is has been abolished.

Regarding its roles and functions from the perspective of SBM, the School Committee is seen principally as an advisory council. In this regard, the committee has a mediation role between the government (executive) and the school community. So, when disputes arise between the school and community, these are directly handed over to the government, by-passing the principal and the education district office.

There appears to be a close relationship between the school committee as a supporting agency (third role) and a fund raising agency (sixth function). Under the previous BP3 system, collecting funds was the only real role. Under the decree this close dual role is still ambiguous at the school level. How can the committee that gives financial support not be given authority as well? Like the Education Council guidelines, the guidelines on school committee do not mention anything about authority. Consequently, it seems that the intention of the decree’s designers regarding financial support to the school is similar to the thinking and practice of the previous system. In the case of state secondary schools, as mentioned in section 2.3.5, the sum of parent's financial contribution as 'tuition fees' to the school is considerable. Very often, for the 'favourite' school in the capital city area, the parental funding contribution is higher than all 
of the government subsidy (concurrent budget) in the same budget period. The decree does not clarify the committee's roles, even as these relate to parental fund raising or other financial matters. This may also be interpreted as another hidden agenda that is embedded in the decree from the central government to hide incapability to support school operations adequately. Unlike school based management policy initiatives in other countries, the decree in Indonesia has not provided national standards for school funding or finance in general.

In the section on organisation, the decree documents state that the “chairman position is not assumed by the school principal”. This statement is inconsistent with the statement on membership of the School Committee which, by default, does not list the school principal as eligible for membership. It could be that the principal of the school is automatically a member of the school committee. However the designers of the decree did not write this in the appendix. Similarly, the decree provides for parents to be members of the committee, but there are no guarantees or obligations for parents to be involved on it.

As with the Education Council, the principal dominates in the establishment of the School Committee; thereby advancing his own agendas at the school level. This can be seen with the mechanism to elect members of the school committee (sixth section), recruitment procedures giving the principal a special position of privilege to agree or disagree.

Regarding organisational arrangements as shown in part B of the Appendix 3, the decree puts the School Committee below the school for which the committee is established. This may be interpreted as the school committee being seen as having a less than significant role. The school committee is neither 
an equal partner nor does it have a horizontal position as a governance entity within the school. Further, the diagram states that other institutions that have responsibilities in educational management have mutual horizontal relationships. In terms of the state school system, the institution that has 'responsibility in educational management' is the educational district office, but the nature of the relationship is direct and instructive to the school. Again, inserting the school committee within an already crowded and hierarchical system may not be appropriate.

\subsubsection{Other guidelines to the decree}

As part of the developmental process for the decree, the central office published a number of materials for public use. These documents were used by central office staff in seminars, organized by education offices at district and provincial levels. This study examined these documents as they contained more comprehensive explanations, sometimes about operationalising the decree.

Unlike the decree's content and appendices which do not mention about SBM explicitly, other official materials and guidelines from the central office were clear in stating that the decree is a form of implementing a school based management policy (Tim Pengembangan, 2002; Suryadi, 2003). These documents confirm the underlying intentions of the decree formulation in terms of a political purpose that is not explicitly stated in the decree itself.

Suryadi (2003) observes that the roles of the education council and the committee involve a paradigm shift. Merely to be collecting money from parents as was done previously in the BP3 is something that has to be ended. Further, he writes that "the BP3 institution is proven not effective to mobilise society participation and responsibility”. 
Suryadi also provides a thorough picture about school conditions with regard to capacity building. He differentiates these into four stages (pro-formal, formality, transitional and autonomous) where each school at a certain stage should be treated differently. However, such a proposal for a kind of "asymmetric" decentralisation contradicts the intentions of the decree where every school is treated the same way. Further, asymmetric decentralisation needs careful analysis and developing of criteria which can measure school conditions. To do this, the central government does not have authority anymore and the local government lacks the capacity to formulate such a policy.

In relation to the subject of authority, Suryadi (2003) presents seven forms of authority that schools can exercise: 1) establishing the school's vision, mission, strategy, aims, symbol, song and rules; 2) acceptance of new students; 3) intra-curricular and extra-curricular activities; 4) procurement of educational means and infrastructure; 5) to write-off goods/equipment which are no longer functional; 6) teaching and learning process; and 7) educational innovation according to the school based management quality improvement concept. Obviously, the range of authority which 'can' be exercised by the school, according to Suryadi's framework, is not new. In fact, the schools were used to this kind of authority even in the previous centralistic system. So, what is presented to schools as devolved authority is but marginal, like the situation now in practice. The suggested exercise of authority is on peripheral issues without any real intentions to empower schools. As a result, this explanation is similar to the unclear stipulations of the decree, and of course there is no authority being transferred to school committees. 


\subsection{Discussion}

The analysis so far has suggested that the school based management ideas in legal documents have merely stipulated the structure of the new educational arrangement, namely the Education Council at district and School Committee at the school level. These two new inclusions are intended to fill in the governance line at district and school level that previously has not existed.

From a process perspective, it is noted that the central government actually needed a longer time to release the decree. This seems to indicate that the central government officials did not really believe in local capacity and commitment at both district and school levels, so they released the decree to slow the pace of decentralisation (see World Bank, 2004). It seems that by being brief and unclear in the decree's content, minimum impact is preferred and a slower decentralisation process is desired.

Further, the decree can be seen as a means to put forward other central office agenda during the autonomy era, without any consultations with district governments where the authority for the education sector now resides. As a result, this is makes managing primary and secondary schools at the district government level confusing. This is because changing from a previously extreme centralisation to decentralisation at the district level is not a smooth or easy transition. While the Autonomy Law is still in its early implementation stage, the central office is also urging significant changes in the institutional arrangements for governance at district and school levels. This is something new and unfamiliar to the Indonesian education system, even for the society at large.

When the decree was signed, it was clear that the intention was to fulfil a mandate of the Law 25/2000. As well, the decree served a political purpose, to 
show that the government cared and was accomplishing public expectations. This is particularly referring to the tension evident in public opinion about SBM implementation during the years before the decree was signed.

In hindsight, bureaucratic views are appearing in the decree's formulations with regard to several issues. First, emphasis has been on changing structural arrangements. The state wanted to show that changes were happening, at least with the introduction of the two institutions for community participation. Further, the two new bodies were not designed to significantly impact on bureaucratic authority; hence they were given minimal support and marginal spaces to operate. The council and committee had little real authority given to them as they were placed at the periphery. Second, the decree imposed a uniform model, particularly for the school committee. It did not have regard for school level, size, location, and the type of community served. This shows a lack of awareness on the part of the designers regarding the diversity and complexity of Indonesian society. Although Suryadi (2003) proposes a school differentiation based on capacity building level, this is not officially written into the decree and consequently the ideas do not bind district governments to implement them. Thus, the nature of Indonesian education cannot be grouped by a single set of criteria on school institutional capacity.

Furthermore, the decree's formulation also reveals central bureaucracy interest, particularly in the establishment of Education Councils and School Committees. Both organisations, according to the decree's appendices, have to be formed through mechanisms where certain parties, namely the education office at district level and the principal at school level, would be driving the changes. The intention of the central office, the authority which is tasked to 
compose regulations such as decrees, is to redistribute power, during the autonomy era, only to groups with similar characteristics and similar backgrounds, who can be trusted based on their experiences from a previous time. Undoubtedly, the central office will protect the district office and the principal from their opponents and others who may not be trusted, especially the community. In other words, with the power they hold, the central office not only alters but also subverts ideas about school based management as proposed by the task forces and expected by the public.

\subsection{Conclusion}

The analyses in this chapter have demonstrated that the MoNE's decree number 044/U/2002 has an ambiguous conceptualisation and lacks clarity about governance and management regarding new organisational arrangements at district and school levels. These criticisms relate to descriptions of how the two institutions will play their roles and functions, and fulfil their mandates. The societal expectations of the decrees have not materialized, due to ill-conceived nature of the decree as well as inadequate capacities at the local level to implement the policy.

The next chapter will analyse the impact of the decree at the district and school levels as perceived and practiced by local stakeholders. 


\section{Chapter 6 \\ PERSPECTIVES AND PRACTICES AT DISTRICT LEVEL}

\subsection{Introduction}

The implementation of the autonomy law (Law 22/1999), starting on 1 January 2001, gave district governments power to exercise full authority in public sectors including education. Undoubtedly this was intended to bring hope and opportunity for betterment of education for each district, but it also gave power to certain actors like mayors, local parliament members, and education district officials. Then 16 months later, the MoNE released a decree which tried to accommodate greater community involvement in education. This resulted a new body called the Education Council at the district level.

The shift of direct authority from the central to the district, bypassing provincial government, resulted in power dynamics and new opportunities between key players. Therefore it was interesting to gather the views and practices of significant actors at the district level regarding school based management policy particularly, and educational autonomy in general. It was also important to ascertain other education stakeholder perspectives about their actions, particularly the views of school supervisors, the teachers union, principals, teachers and school committee members.

The analyses of respondents' interviews, both from district and school levels, revealed that there were three key players with different degrees of influence. Firstly, district parliamentary members and the mayor were regarded 
as a higher authority at the district level with moderate influence upon education; secondly, the district education office which had significant authority and influence; and thirdly, the education council who had little authority and limited influence.

Following this discussion regarding influence a number of issues relating to the key players will be considered. Several documents which related to education autonomy policy in the district (such as the district official budget and establishment of the education council) were analysed. Information about respondents’ backgrounds will be presented first to provide a context.

\subsection{Interviewees’ background}

Ten people were identified as key players at the district level and they participated as interview respondents. All of them were males representing different occupations and positions at district level in the education sector (Table 6.1). Six of them were district government employees (I-1, I-2, I-3, I-6, I-7 and I24), one worked as a lecturer in a private university (I-4), two were recently retired civil servants (I-10 and I-23) and one was a local member of parliament (I-9) from a new party which held a seat from the 1999 general election. Except for I-4, I-9 and I-24, all respondents had worked in the public education system for more than 15 years. Seven out of ten respondents had worked as teachers for more than 10 years (I-1, I-2, I-3, I-6, I-7, I-10 and I-23); five of them (I-1, I-6, I7, I-10 and I-23) had held principalship positions for some years; three were officials in the education district office (I-7, I-10 and I-23). All respondents held an undergraduate degree, and two of them (I-4 and I-24) also had master degrees. Three respondents (I-1, I-2 and I-6) had identified themselves as not being local 
people, whereas the rest originated from Lombok. Some respondents could be defined as average-income earners, owning their own homes with one motorbike (I-1, I-2, I-6, I-23 and I-24), whilst others could be considered as above average because they had more than one house and one or more cars (I-3, I-4, I7, I-9 and I-10).

Table 6.1 Interviewees' profiles

\begin{tabular}{|c|l|}
\hline Identity & District level category \\
\hline I-1 & School supervisor \\
\hline I-2 & School supervisor \\
\hline I-3 & Teacher unions \\
\hline I-4 & Education council \\
\hline I-6 & Teacher unions \\
\hline I-7 & Education district official \\
\hline I-9 & Local parliament member \\
\hline I-10 & Education council \\
\hline I-23 & Education council \\
\hline I-24 & Official at the mayor office \\
\hline
\end{tabular}

\subsection{District level policy}

Starting from early 2001, each district in Indonesia had been managing the public sector authority which was generally bigger than those managed by the central and the provincial governments (see sub-section 2.3.5). In terms of the education sector, there were three significant aspects of decentralisation of management by the district government: institutional and personnel conditions, finance and curriculum (see: Usman, 2001). Certainly each district government 
comprising the mayor (executive) and local parliament members (legislative) played crucial parts. In the following section, the policy that was established at district level is discussed from the perspective of these two key players.

One instrument that can measure educational policy at the district level is the district regulation (Indonesian: peraturan daerah or perda). The regulation can be proposed either by the executive or legislature, but it needs to be discussed extensively in the legislative forum by both parties. Unlike several districts which have released regulations based on the MoNE decree regarding the education council and school committee, the Municipal city of Mataram has not, up to now, released any ${ }^{1}$. Official reports from the Law Division of the Mataram City Secretariat of the Mayor's Office (from 2000 to 2004) did not indicate any district education regulations. This implies that the legislative vision about district education in the autonomy era has not been readily realised. By contrast, there were 39 out of 75 district regulations that were released between 2000-04 were concerned with local taxation in order to increase income for the district government. As noted by two respondents, from the mayor's office and a supervisor, it was the executive not the legislature office that proposed the regulation:

So far, I've seen that most of the district regulations are the executive's initiatives $(\mathrm{I}-2)^{2}$.

\footnotetext{
${ }^{1}$ The Municipal City of Malang, East Java, has stipulated district regulation no. 13/2001 on 20 October 2001 about System of Educational Implementation in City of Malang; The Municipal City of Bandung, West Java, has stipulated district regulation no. 20/2002 on 2 May 2002 about Educational Implementation in City of Bandung; The District of Dompu, in the same province as Mataram, has stipulated district regulation no. 19/2002 on 30 December 2002 about Education Council and School Committee. All those regulations, except from Malang, its structures and contents are similar to the MoNE decree number 044/U/2002 (see Chapter 5) which of course shows little effort has been made when composed the regulation. But, of course, these show real concern from the legislative to education sector with regulation as an instrument of policy.

2 "I” was the code for data from interview, and " 2 " was the number of participant in my list.
} 
The mayor's office is the main source of district regulations; the legislative did not get involved much and mostly agreed with proposed initiatives (I-24).

Regulations relating to local taxes rose significantly after autonomy implementation proceeded throughout Indonesia because most district governments were concerned they might not balance their budgets. This had also occurred in Mataram where, since 2001, more than half of the regulations issued were about local taxes.

Besides the legislative body, the district parliament is divided into several special commissions dedicated to a particular sector. In Mataram, the education sector in the legislative is administered by the E Commission, which is composed of six district law makers from five political parties. Generally, members of this commission are perceived as more competent and are aware of education issues. When conducting field work research to collect data for this study (which was 3 years after the autonomy; and 20 months since the MoNE decree), I noted that there were no decisions about school based management and educational services from the commission. The most frequent activity of the $\mathrm{E}$ Commission was hearings, which were based on an official request addressed to them from the district education office, school supervisors and the education council (I-7, I-1 and I-10 respectively). This implies that implementation steps and initiatives regarding the education sector were originating with the executive.

A number of interviews with several stakeholders were undertaken at the district level. This included ascertaining the personal views and interests of the district law maker. This confirmed that the legislator and indeed the $\mathrm{E}$ 
commission seemingly had little understanding about education. The comments

below came from school a supervisor and education district official respectively:

In my opinion, the district parliament, particularly the members of the E commission don't know about the substance of education issues. In most cases they only consider the budget aspect. [Researcher: Is it because they do not come from the education sector?] I think to give much support in this public sector, one does have to have experience in the educational sector, and most importantly s/he must understand the substance of the issue. It is something that in fact our lawmakers do not (I2).

Researcher: What has the legislature suggested to your office? Participant: They have concern about social development issues including education. However, the concern is only rhetoric. Essentially, they don't understand most education issues. Most legislative members are stupid. Most of them did not graduate from formal secondary schooling; I have signed many of their Package $\mathrm{C}$ certificates $^{3}$, which plainly showed their quality. So, how can they understand the issues? (I-7).

These views were also reflected somewhat in the response by the lawmaker.

Several questions directed to the legislator (such as executive responsibility to education sector, regulation and policy, and quality issues) were not responded to as was expected. The participant's [I-9] responses were as follows:

[regarding the executive concern] Firstly, we try to make the education sector in the district budget reach $20 \%$ proportion. Secondly, we support acceleration of classes at general secondary school level, which should not only shorten the years of schooling from 3 years to 2 years, but also increase the number of subject matters that have to be given to students. So, in those two years students learn not only 10 subjects, but 15 , even 20 subjects. That's what I call acceleration.

[regarding regulation and policy] I see that the district government already has a good concern for education, even though in terms of action it does not. So we as the legislative always apply political pressure. The real obstacle of course is

\footnotetext{
${ }^{3}$ Package C certificate is an out-of-school program equal to formal secondary school level which mostly involves just sitting for an exam rather than years of learning (see section 2.2). The new legislation of the general election stated explicitly that a candidate for Member of Parliament was required to have at least an secondary school certificate or equivalent.
} 
about funding. We do not have much flexibility because of limited resources.

[regarding educational quality] Each time in the political arena, such as the conclusion session of the legislative process, I always emphasise that each school must have a library. How can we eat when the food has to be shared? Library books are like food which, each day, has to be consumed in enough portions, like we eat our food.

Further, a principal of one state secondary school shared his experience when he dealt personally with the law maker from the E Commission. This concerned one extra-curricular activity in the school which was usaha kesehatan sekolah (Indonesian, abbreviated as UKS) or school health service. In Indonesian "usaha" refers to service but also can mean trade that could result in income. The principal didn’t understand what was proposed by the Member of Parliament:

One day, one member of district parliament proposed to us that UKS should contribute to the district. [R: In terms of what?] The contribution is in terms of money. The member had perceived the UKS as a school business, and hence his proposal for it to give its revenue to the district government. It is funny, the UKS or school health service, is in fact a school subsidized activity. The member did not understand and was confused. This is because he really did not understand about education (I8).

Such lack of understanding possibly accounted for the lack of promulgated regulations. The extent of knowledge and competency in the education sector seem to be related to the inactivity of the members of parliament. The quality of legislators is certainly one of the serious problems that the district faces particularly when parliament's response has not occurred. A confirmation from one school committee member reflects this issue:

In this autonomy era, the parliament and the E Commission particularly are having substantial authority, no doubt about that. But, if they do not understood education, what can we say? It is a problematic situation which cannot be solved, except by another general election (I-14). 
In the absence of specific district regulations on education and recommendations from the education commission or the district parliament, the legislature's commitment can only be detected indirectly by the allocation of education sector expenses in the district budget. The district budget is also a district regulation that is the result of contacts between the mayor and the district parliament members. One respondent (I-24) noted this as a planning movement between the executive and the legislative during the implementation of district policy. Although, according to I-24, education funding arises from district policy, it is really a consequence of the political process between the mayor and local parliament members. The institution which designed the budget for the education sector was the district education office. The district budget was a public document and was freely accessed for this study and the 2004 budget for the socio-cultural sector is also analysed.

The total amount of the 2004 Mataram City budget was 218.318 billion rupiahs or equal to US\$21.831 million (Mataram District Regulation no. 9/2004, shown in Appendix 3). From that amount, 20\% or more than 44.2 billion rupiahs was allocated to the education sector (non-budget salary). The district parliament's commitment to education was therefore relatively good. In other words, in terms of quantity of the fund, the legislative body agreed to what the executive proposed in the district budget. This significant percentage dedicated to education is almost one-fifth of the district budget that had to be allocated according to the national requirements. One respondent observed:

I think in terms of budget allocation for the education sector, it has already reached $20 \%$ a year. The real problem is how far that big amount of budget money is effective and efficiently spent for educational purposes (I-24). 
As shown in the Table 6.2 which summarises the district budget in the education and culture sector, 34.165 billion rupiahs (77\%) was designated for some infrastructure projects. However, the first and second project took $85 \%$ of that amount (29 billion) to fund school refurbishment and to build three new secondary schools. This decision arose from the Mayor's wishes for the education and the city, as explained by a board member of the education council:

The decision was coming from the city government, particularly the mayor. He has a big concern for the education sector. He also wants Mataram as a capital city of the province to become a barometer for everything, including education (I-10).

Table 6.2 Budget Allocation for Education Sector year 2004

\begin{tabular}{|l|r|}
\hline I. Education and Culture Sector & $\mathbf{4 4 , 4 2 2 , 1 0 8 , 1 0 0}$ \\
\hline $\begin{array}{l}\text { 1. Infrastructural projects } \\
\text { (school refurbishments, building } \\
\text { rehabilitations, construction of three } \\
\text { new secondary schools, seven new } \\
\text { classrooms, and fence for two } \\
\text { schools) [1-5] }\end{array}$ & $34,165,000,000$ \\
\hline $\begin{array}{l}\text { 2. Programs for educational quality } \\
\text { improvement [6-7] }\end{array}$ & $4,476,588,100$ \\
\hline $\begin{array}{l}\text { 3. Assistance fund for school } \\
\text { examination and new student } \\
\text { admission [8-10 \& 13] }\end{array}$ & $1,180,000,000$ \\
\hline $\begin{array}{l}\text { 4. Improving teacher educational } \\
\text { qualification [11, 14 \& 16] }\end{array}$ & 350,000,000 \\
\hline $\begin{array}{l}\text { 5. Incentive for teacher and } \\
\text { administrative staff [12, 19 \& 21] }\end{array}$ & $1,210,000,000$ \\
\hline $\begin{array}{l}\text { 6. Training for school committee } \\
\text { members [15] }\end{array}$ & 75,000,000 \\
\hline $\begin{array}{l}\text { 7. Scholarships fund for students [17, } \\
\text { 18 \& 20] }\end{array}$ & $1,025,520,000$ \\
\hline 8. Culture activities programs [22-34] & $1,340,000,000$ \\
\hline Source: summarized from Mataram district budget year \\
2004 for education sector (Appendix 4). \\
note: - amount in Indonesia's rupiahs (1 US\$ equal to 10,000 rupiahs) \\
- number in bracket is original list from point of budget allocation
\end{tabular}

One refurbishment project was the renovation of three elementary school buildings, one school in each sub-district, with the physical appearance being 
satisfactory by local standards. However, there were some critics of this kind of approach:

I am very disappointed when the district government tries to improve education quality and comes up with physical infrastructure projects. The three primary school buildings were refurbished, and people saw it as a shopping mall. The government clearly wanted to show Mataram as a developed region (I-1).

I think, what is supposed to be considered by the district government is to allocate funds for something that is really needed. It should not be used for that kind of wonderful building refurbishment (I-9).

A second comment was from a legislative member. He also disagreed with the project because the school building had a distinctive paint colour, the symbol of the mayor's political party.

At the secondary school level, the mayor's personal influence was also evident. A comment from a board member of the education council confirmed this as follows:

The opening of several new general secondary schools in Mataram was because of the pressure from the society. Students' numbers passing junior secondary schooling have been increasing, and all their parents wanted them to study in state schools. The parents said that if their children were not enrolled, they will burn down the schools. The mayor told me personally about that. So, the new secondary school buildings were erected in Selagalas which are excellent. Right now, other superb secondary school buildings are being constructed (I-10).

Furthermore, the secondary school students' admission policy signed by the mayor was an important feature. It stated that each school had a quota for students who lived near the school, which operated before admitting students outside Mataram. The purpose of the policy was to give schooling opportunity at state schools to Mataram residents and this was considered to be a 'geographical 
fence' policy. Interestingly, this kind of policy had been long supported by the legislators. One legislator said:

It should be a policy which is giving priority to students who are living in Mataram. This means, regardless of low academic achievements of these students that does not imply they cannot enter state schools in this particular city (I-9).

The policy was easy to understand. This is because it directly impacted upon political support in elections and the pupils at secondary level were future voters. The policy has resulted in larger classes and parallel class developments and this could impact upon achievement levels (I-8, I-16 and I-20). The principals' concern about this was new because state secondary schools in Mataram were previously perceived as good schools with excellent academic results. The mayor's policy was recognized as direct interference in schools. One principal noted:

My experience in this autonomy era is that we cannot be free from its inefficiency - there is to much interference from the district government. Especially in terms of new students' entrance, the government practically uses us as it wants on many occasions (I-20).

The Mataram mayor also released a circular letter (no 420/526/Kesra/2001 on 28 August 2001) relating to secondary schools. The letter gave permission for state secondary schools in Mataram to regularly collect amounts of money from parents as a fee for the registration of their children at public schools. This letter indicated that the previous practice already established in state secondary schools through the BP3 could persist (discussed in more detail on sub-section 7.4.2 and section 7.6). In spite of the intention to accommodate all secondary school expenses via the district budget, the mayor was relying on parents' contribution to help the school fulfil its operational cost 
(non-salary budget). A comment from one school committee member regretted such action:

The school participation rate at secondary school level [in Mataram] is $31 \%$. It should become a serious concern for legislators and executive to solve, because this means $69 \%$ of children ages 15-18 are not registered as students. If people consider the need for increasing participation, few will oppose an increase in the education budget, but this should not be for refurbishing and constructing new schools. It has to be emphasised, that the key need is for children to be supported financially by the district government to continue their education (I-14).

The mayor was also involved in issues relating to the results of the secondary school final examination. The central office in 2003 increased the threshold of exam results, but the Mataram mayor refused to accept that policy (Bali Post, 2003). The new standard to pass students from secondary school level in three subjects was regarded as too high, not only for students in Mataram but all across Indonesia. The mayor's actions could be interpreted as an effort to protect Mataram's students and its parents regarding the possibility that $70 \%$ of students would predictably not pass the final examination. It also reflected tension between district and central government regarding their respective powers which were not clearly defined. However, it was indicated that the already established programmes and policy of the mayor were not improving educational quality as required by the new examination standard. As previously mentioned, it could readily be interpreted as a politically motivated decision.

As discussed above, district policy regarding education, and particularly school based management, from the legislature and the executive was not well articulated by both authorities. Political reasons seem more salient in terms of policy development at the district level. 


\subsection{District education office}

The district education office was a new institution as part of Mataram district government. Previously there was a district education office which had limited authority to administer 3M (men, money and materials) at the primary school level. With increased autonomy in each district a new office was required and this catered for both primary and secondary levels. An explanation from a respondent illustrates this situation:

Mataram district education office is a new body of government. The demands of this new office meant that experienced civil servants were needed. As a result many officials from the provincial education office joined and staffed this new body (I-24).

With the beginning of the autonomy process in 2001, there was tension between the Mataram education office and the provincial education, sport and youth office. The sources of tensions were related to a number of issues: personnel, finance and materials; the appointment of principals at state schools; and permission for teachers to attend training outside the province (Lombok Post, 2001). Interestingly, the six other districts in the province reacted differently to Mataram. They mostly followed what the province education office told them to.

The Mataram district office perceived what the province office did as "a tendency to sustain an old paradigm” (Lombok Post, 2001). The problem was that preparation for autonomy was not complete and this resulted in conflict (Soewartoyo, 2002). However this situation also arose from individuals since both officials previously came from the same office (province education office in centralisation era) and people at the district office wanted to demonstrate their new power and authority. Eventually authority came to rest at the district level. This experience has meant officials from the province education office often face 
difficulty when dealing with Mataram district education office. A comment from a teacher explains this as follows:

Officials from the provincial education, sport and youth office, said that when they want to ask something from Mataram district education office, they often find it very difficult. They have to edit the language of their letters in order to make them appear not to be perceived as giving instructions. In other words, the language they use is not like a command, otherwise the district office will not reply to the letters (I-13).

The feeling of a 'new centre' emerging after the transfer of power (via the autonomy law) was undeniable. This appeared more salient in the education sector which was the largest 'industry' in the district. It employed teachers and administration staff that were the largest proportion of civil servants and it utilised a significant amount of the government budget for salary. It also involved nearly every household who had school age children. The power shift was easily recognized by education district officials. They also were more aware that they could now do many things which previously had been inhibited by the provincial office.

As a result, the district office implemented many administrative processes to demonstrate their new self confidence. The Mataram district education office had always had a slightly different policy to other district offices (in the same province) relating to such matters as teachers' personnel affairs, decisions about beginning the academic year, and details about the end of term examination. Historically all of these were stipulated uniformly at provincial level by the province district office. A comment from a teacher expressed this:

The disputes between the province education office and Mataram district education office were obvious. This is seen 
in the decision about school holidays. Other districts followed the dates province office told them, but Mataram did not. Instead, Mataram makes its own academic calendar which is completely different. Last year's school holidays also had a different timing for Mataram (I-21).

In addition, the perception of a 'new centre' was also held by school supervisors. Although organisationally the supervisors and the district education office had a coordinated relationship, district officials' self confidence impacted on supervisors as well. A supervisor expressed this as follows:

As part of our main job as new school supervisors ${ }^{4}$ in Mataram, we suggested some visions. The last vision stated that supervisors 'gave recommendation to relevant officials regarding transfer and promotion of educators'. This was a role that supervisors wanted. However, the education office could not accept the role and rejected it. Further, mostly their officials see us as their subordinates whom they can instruct as they want, which is occasionally their practice (I-2).

Some of the work of the new authorities had good results but other outcomes were not desirable. For instance, in terms of processing teachers' personnel affairs, the district office was a pioneer in comparison to other districts. Introduced changes made administration simpler. For example, previously bureaucratic red tape made teachers' promotions most difficult, because decisions rebounded between the school-district-province and the central office. Comments from a teacher and district official confirmed this as follows:

A good thing in the autonomy era relates to teachers' personnel affairs. The time needed to process a decree about my promotion as a government-employee-teacher is shorter than during the previous era. This is because many things can be solved locally, and the province or central offices do not have to deal with these matters (I-5).

Since the autonomy began, we had been processing teachers' promotion directly to central office. Faster and simpler

\footnotetext{
${ }^{4}$ The school supervisor office in Mataram like the district education office is a newly established institution. Previously, all schools in Mataram were supervised by supervisors from province education office.
} 
processes have been used, providing a model for other districts to follow. The province office had reluctantly given this authority, and it does not have much choice, especially when we can prove that we are doing it better. We have already processed very senior applications, including for teachers who are pursing higher ranks on the government employee ladder (I-7).

It seemed that the main obstacle for the district education office authority was coming from their superior, the mayor. In fact, several district regulations in practice were rolled-back by the mayor, such as regulations relating to principals' positions and teacher transfers. One teacher and a principal gave examples of this in relation to the relocation teachers between public schools in Mataram by the district office:

Last semester the district education office was implementing a teachers' relocation programme. However in a particular public school, where one of the teachers was a close relative of the Mayor, he complained and then the transfer was blocked. This means, the real power is held by the Mayor. In fact, the whole program regarding teachers' relocations is stopped and no one has spoken about it since (I-15).

Regarding the programme for transferring teachers to another location, the district education office is not brave enough to implement it properly. The district officials must face the mayor's office, and when this happens, the district office backs down. One of my teachers was placed to teach in another general state secondary school by that program, but because of many protests regarding the relocation program, the teacher never moved (I-20).

Meanwhile a district official explained the tensions that occurred when his office proposed teachers as candidates for principals' positions:

In terms of principalship selections, this issue always seems to present a difficulty. While, on the one hand, the system is short of qualified candidates, on the other hand our recommendations of suitable candidates often are rejected by the mayor's office. That is our situation; teachers who are short listed are not always permitted to be appointed (I-7). 
Other stakeholders also discovered that the transfer of power was not beneficial. For example, a teacher complained about the quality of the training organised by the district office:

The teacher training that we had was really unprofessional. It could be that this was a new thing for the district office; eventually it also showed their limited capability (I-21).

In addition, another comment from a school supervisor (who was invited as a speaker for a training event) noted that:

This morning, the district education office was organising a certified education-and-training for candidates who will become state school principals. The training is conducted only for three days. This is supposed to be a serious training and not just a socialization activity. The way the training is organized and its short duration do not support this assertion. I think, the programme is meant only to show that the principals' candidates at least have attended. The principals are engaged in what I call an economical training (I-1).

This kind of activity was reminiscent of the practices in the previous administration and indicated that there was a desire to simply fulfil minimal standards of bureaucracy. It could have been exploitative (see sub section 2.3.4).

Moreover, a greater concern related to the district budget process and the authorities for accessing this. As previously mentioned, although the district budget is considered and authorised jointly by district parliament and the mayor, the initiators of it were the district education officials. An explanation from an official of the mayor's office illustrated this:

Before the autonomy era, the funds for the education sector never reached one billion rupiahs [equal to US\$100,000]. Then since 2001 the education officials have administered forty times that amount like in the budget of 2004. You can imagine the effect on the officials. Many argue that it is normal, because of the volume of matters they handle and their authority and there is also consensus regarding budget priority for education nationally. However, what is more important? Is the big budget really effective and efficient? In 
my many years in the board of planning and development office, reviewing proposed budgets in the education sector, I have always ended up with heated debates with the officials. You can check yourself, issues of proportion or whether programmes that are listed in the budget plan are on target. Because most of them came from department of education office [in the New Order], the budget plans are merely for 'copy and paste' from their usual office activities, such as raising flag ceremony competitions (I-24).

One source stated that the reason for this was the quality of its human

resources. A school supervisor and district education official commented upon this:

In relation to operating educational services, especially at the district education office level after autonomy, it is noted that many of the employees are not from education backgrounds. [R: Don't they understand educational issues?]. This means, they find it difficult to comprehend the issues. These are predominantly officers with much practical experiences as heads of sections in non-education offices. Many of them are coming from district governments and had positions as village chief (I-2).

Some positions in my office are filled by officials who have backgrounds from the ministry of home affairs. Some of them even served in the military. This means that many positions are not held by the right people. For instance, two of heads of sections in the district office are ex-village chiefs. Mostly they are starting from scratch to understand their own jobs. We regretted this situation (I-7).

It would seem that the problem was structural and could not be solved in a relatively short time. One of the problems during the autonomy era was that positions at district level are decided by the mayor, a person who does not have much information about applicants’ background for most positions. Knowledge and skills required for the educational official position for example seem not to have been considered carefully.

The above explanation probably accounts (at least in part) for why the performance of district education office, in terms of education budget proposals, 
tended to follow the old tradition. In addition, according to one district official, it was noted that most did not want the previous practice to be changed:

In terms of technical matters, such as how is teaching and learning practiced in school, how are examinations conducted, or how supervision is undertaken, most of these have remained the same. We are not brave enough to change all of that (I-7).

Similar decisions also happened relating to the funds parent contribute to state secondary schools. The head of the district education office, unlike the mayor who issued a circular letter, released an official letter giving permission for public schools to collect funds (head of district education office decree no 422.2/632/B/Dik/2001 on 31 July 2001). The decree clearly showed the district education office adopting the previous practice. Even when other regulations are promulgated (such as the MoNE decree concerning education council and school committee on April 2002 and the new Education Law on July 2003) there was no change in policy regarding the collection of money from parents on a regular basis.

Regarding the school based management policy which became the official policy based on the MoNE decree, the district education office also did not have clear directions. The only indication that explicitly appeared was the training program for school committee members, as listed in the district budget (point 6 in Table 6.2). The training was for 200 school committee members to improve their knowledge. However, it was late in coming (2 years after the introduction of school committee) and was also conducted in a manner that reminded everyone of the power issues. One respondent noted:

What I see in this particular training is that the district education office wants to show that it has the real power. The district office wants to show that the school committees are its 
subordinate. The office uses the training to impress on trainers that the activity is funded and organised by the office (I-2).

Several respondents from the secondary school level commented about the district education office policy in negative terms. A school principal commented:

What I see of the education bureaucrats is that for the most part, they don't understand comprehensively that school based management is about educational change. Previously all instructions came from the central office in Jakarta then it was controlled at the local level. Nowadays, those roles should be facilitated and monitored by bureaucrats. However, I see that, many district office working programmes are positioned by the bureaucrats and that schools are required to follow everything, not giving any flexibility. In terms of technical matters, we are always giving the bureaucrats academic-professional arguments in order to make them not force us, but they usually counter it with authoritative and political reasons, which of course do not always match (I-8).

A school committee member who had years of experience as a BP3 member also had similar views:

Currently, as they said, we practice school based management ideas, but in reality this is not fully SBM as many things are still decided by them. For instance in terms of teacher selection, it should be that the school has the right to do that, but the bureaucrats are not allowing this to happen (I-11).

A school supervisor explained this situation in terms of the structural limitation.

He concluded that:

I see some kind of a gap between school and district education officials. In terms of SBM the mode of thinking of educational bureaucrats is not fast as teachers and principals want. That is why from my point of view, I believe that the district education office should not be involved in technical matters in education. They must not be organising technical activities. They can play effectively in terms of policy and support for schools (I-2).

Likewise, policy practiced at the district level was of concern. One issue more salient than others was about students' admission to state secondary 
schools. Several principals noted that the pressure from the district education office was overwhelming and made them change school plans because of larger classes or adding of new classes (I-8, I-12, I-16 and I-20). Two principals personally confessed that education bureaucrats also pressured them to accept some students without an entrance test (I-12 and I-20).

\subsection{Education council}

Unlike the Mataram district education office, the Education Council was a new institution established with new personnel and new governance arrangements. Officially, the education council was stipulated by a Mataram mayor decree no 253/VI/2002 issued on 5 June 2002. This means it was only 2 months after the release of the MoNE decree requiring the setting up of education councils in each district. The rapidity of response and smoothness of the process to create an Education Council at Mataram was something that indicated interference from the government. Further, as stated by a member of the education council, the council was not structured and prepared via an official preparation committee as dictated by the MoNE decree. A comment from an education council board member explained as follows:

Firstly, several government officials, including the head of the district education office called Mr. X to talk about the people best suited as education council members. Then, they got some names and called the candidates to ask about their willingness to join. Following that, there was a meeting where the head of the district education office explained the education council, based on the decree, and its tasks. Finally, the Mataram education council was formed with its board members. Then, based on acclamation $\mathrm{Mr} \mathrm{X}$ become the head of the education council (I-23).

This shoulder-tapping method to decide the head of the Education Council by the educational bureaucrats was something that was expected (Muslim, 2004, 
personal communication). Moreover, this demonstrates how the education council members were hand-picked jointly by the head of the board and district education officials. The composition of the council was something appreciated by the monitoring team from the central office according to one board member:

The council consists of seventeen members, as suggested by the decree and includes a chairman, vice-chairman, secretary and treasurer. Those representing the society make up more than $90 \%$, though there are 4-5 bureaucrat. But, not many of the bureaucrats are better equipped. That's why according to a team from the central office in Jakarta, Mataram education council is the best because its members are better suited as the decree stated (I-4).

However, the whole recruitment process invited complaints from several stakeholders. An explanation from a representative of teacher unions is typical:

What really happened was that educational bureaucrats were involved deeply in creating education councils in hastiness. This means that practices that are necessary to establish new processes through society-based initiatives are only given lip service. In fact, educational bureaucrats positioned many of their own favourite people inside the institution (I-6).

Two members of the council gave explanations for why the institution was established relatively quickly (I-4 and I-10). Previously in Mataram, there was the School Council, its functions and roles were similar to the Educational Council, based on the MoNE decree. However, the School Council acted like a non-government organisation outside district education office influence. Accordingly, it would be considered appropriate to create a new institution with legal backing and district influence.

According to the council official report, several activities had been completed by the Education Council since it was formed to early 2004. This included socialise about the education council and the school committees, hearings with legislative, surveys to schools in Mataram regarding school 
committees and a seminar about the new curriculum. Although the council was to be given funding from the district government, in the last 2 years it was not allocated any funds. Consequently limited support to the Education Council has lead to complaints:

Based on the mayor's decree the district government has clearly stated that every expense should be funded by the district budget, but up to now this is not yet seen. Fortunately central government has provided grants in the last two years to fund all activities (I-10).

Actually we received little support from the government. We don't have a secretariat. No staff are helping us even with little things such as office stationary. As a board member, I sometimes have to deliver letters personally to schools or district education offices. In short, we are inhibited from working effectively (I-4).

Further, comments from some respondents suggest that the relationship between the district education office and the education council were not symmetrical as suggested by the decree. One school supervisor and a member of parliament directly noted what education council members said to them:

A board member of an education council once told me that the council is like a kite that is meant to fly high but the strings to make it fly are short. So, how can the council 'fly' when everything is limited. In fact the council is pushed to become a volunteer institution by the district office (I-1).

There is an impression that the education council is a subordinate of the district education office. [R: why? Education council is an independent organisation]. The members explicitly told me so. That's why we suggested to the mayor that it should not be the district office that is the boss to the education council (I-9).

The above responses were not surprising to many because of the way the council

was formed. A representative of the teacher unions commented:

The bureaucracy has an interest in co-opting members into each institution at the district level in order to preserve its power. That's why the education council is needed to be part of its power structure. The council has societal representatives 
who can contribute and participate on educational issue I-6).

Some respondents from district and school levels had diverse views about the Education Council and its activities. A school supervisor, a principal and a school committee member for instance noted that the Education Council consisted of educational experts who continue to give valuable input to the executive and legislative (I-1, I-8 and I-14). Another teacher commented, however, that the Education Council was only a sophisticated name and it had little practical functions for the school (I-15). A school supervisor was critical of the seminar organised by the council:

Last month I found an invitation from the council regarding a seminar about a new curriculum. When I read the invitation, I was disappointed. This is not a role for the council to play. I am happy if the council facilitates the empowerment of society or groups of people in terms of community participation in education. That kind of seminar is not for the council. I think that the district education office is more appropriate to organise such a seminar. Further, I am a bit worried that members of the education council do not really know the key tasks of the education council itself (I-2).

One teacher suggested that the council should be named the 'school rehabilitation council'. He argued that, “most of the council's job focussed on school rehabilitation projects, because it was required by the central government to liquidate the fund” (I-3). This cynical view was also confirmed by a board member of the council, but he also noted that potentially the council could play an even bigger role here when dealing with the district education office. To illustrate, one council member explained:

We also involve the district education office in several activities such as in block grants from the central government to refurbish school buildings; and scholarship grants for students who come from low income families. The official letter to liquidate the fund is jointly signed between us as without our agreement they will not get the money. This is 
because the requirement from the central office is that the education council has to be a part of the committee to administer the grants (I-10).

The explanation above indicates the tension between the district education office and the Education Council. The council had an advantage because it was an institution with community representatives and founded on regulations stipulated by the central government. However, as discussed, this advantage in terms of power dynamics is limited and infrequently demonstrated.

\subsection{Conclusion}

In this chapter views and perspectives at the district level about educational autonomy in general and SBM policy in particular were discussed. Key stakeholders who held authority and could make substantial changes to SBM still had not utilised their power and influence. Knowledge and skills needed to facilitate school autonomy were not comprehensively understood. Rather, practices of power and self interest were dominant. Consequently, the future of SBM looks bleak.

These research findings point to the need for education of the local legislators and executives about the SBM as a top priority. Enhancing capacity of district education officials in general will lead to much more effective ways to support the Education Council and schools.

Given the findings in this chapter, stakeholders at the school level in Mataram could find SBM implementation difficult, particularly while their higher level institutions are unaware of such complexities. The next chapter explains how principals, teachers and school committee members dealt with issues of SBM. 


\section{Chapter 7 \\ PERSPECTIVES AND PRACTICES AT SCHOOL LEVEL}

\subsection{Introduction}

The introduction of school based management policy as a form of educational reform challenges and confronts school stakeholders. Basically, in order for the policy to succeed, it should take into account the real situations of schools, in particular the views and practices of educators, including school committee members. Therefore, this chapter will discuss the practices and views of school stakeholders about school based management in state secondary schools in Mataram, Lombok, Indonesia. It will consider the views of principals, teachers, and school committee members. The stakeholders' understandings, perceptions and practices regarding the SBM policy, devolution of authority to schools, parents' and community involvement and the effects on the school committee and school are considered. Background information about respondents who participated is presented first to give a context for the analysis of the data.

\subsection{School stakeholders' background}

This section presents some basic data about school stakeholders in Mataram, Lombok, who participated in the study. There were 5 principals, 57 teachers and 21 school committee members. Some of these, 4 principals, 6 teachers and 5 school committee members, were later interviewed, and two out of five secondary schools participated in site studies. Some information 
regarding the state secondary school situation in Mataram is also considered, giving information on student enrolments and class structures.

\subsubsection{Principals' background}

All principals of the five state secondary schools who participated in the study were male, as shown in Table 7.1. In the past only two of the schools had been led by a female principal. A gender disparity for principalship positions in state secondary schools is an issue. At this level female principal underrepresentation is evident, compared to junior high or elementary schools in the same city. Table 7.1 also summarises the principals’ basic information.

Table 7.1. Principals' basic information $(n=5)$

\begin{tabular}{|c|c|c|c|}
\hline Q1 & $\begin{array}{l}\text { Gender: Male } \\
5 \quad(100 \%)\end{array}$ & & \\
\hline Q2 & $\begin{array}{l}\text { Age group } \\
45-50 \\
2\end{array}$ & $\begin{array}{c}\text { more than } 55 \\
1\end{array}$ & $\begin{array}{l}\text { Average } \\
52 \text { years }\end{array}$ \\
\hline Q3 & $\begin{array}{l}\text { Total years as principal } \\
\text { less than } 2 \text { years } \\
\quad 2\end{array}$ & $\begin{array}{l}\text { 4-5 years mor } \\
1\end{array}$ & in 8 years \\
\hline Q4 & $\begin{array}{l}\text { Have been principal in } t \\
\text { less than } 2 \text { years } \\
3\end{array}$ & $\begin{array}{l}\text { is school } \\
4-5 \text { years } \\
2\end{array}$ & \\
\hline Q5 & $\begin{array}{l}\text { Highest educational qua } \\
\text { Bachelor degree } \\
\qquad 4\end{array}$ & $\begin{array}{l}\text { fication } \\
\text { Master degree } \\
1\end{array}$ & \\
\hline
\end{tabular}

The principals were in the middle age group with at average age of 52 years. It is not surprising that the principalship is only available for teachers who have served at least 20 years. They had reached a higher rank in the government employee hierarchy after being proposed by their previous superior 
officers. Principalship positions in Indonesian schools, particularly at the secondary level, are highly respected and competitions for the positions are considerable. Often a teacher who is selected as one of the four vice-principals in a school is most likely to become a principal in the future.

Three out of five principals had served for more than 4 years. This means they had been principals for more than one term. Furthermore, two principals had been principals previously in other schools before they transferred to their current schools. Only two principals had served less than 2 years. In addition, three out of the five principals who had served more than 4 years were considered experienced and knowledgeable in all kinds of school business.

All of the principals had undergraduate degrees, a bachelor degree being a prerequisite for the position. One principal who had an MA from the United States, had also served as an English teacher and supervisor, and later won a scholarship to undertake postgraduate study before becoming a principal.

Interestingly, three principals originally came from the same school, Mataram state secondary school number 1 . This school was considered highly in the province by the public because students who graduated from it had good academic results. It had many good teachers and was regarded as a training ground for principals for state junior and secondary schools in the region.

\subsubsection{Teachers' background}

A total of 57 teachers participated in the study. From this group, 23 (40\%) were female (Appendix 7.1). The 40\% female distribution reflects the teachers' gender distribution in state secondary school teaching staff (although in elementary school female teachers are always the majority). However, among the 
secondary teachers, gender difference is not a professional issue as female teachers or their male counterparts are able to teach any subject at any grade.

Generally, most teachers in this study were more than 40 years old and the average teaching experience was 14.4 years. This means that many teachers who participated in this study started their careers in the 1980s. At that time, the University of Mataram, the major supplier of teachers in the province, had just begun graduating students in several subject areas such as English, Indonesian, biology, mathematics and social sciences (civic education, economy, history). As graduates, those teachers had signed official employment contracts to become civil servants and were placed in several new state secondary schools including Mataram.

The distribution of teaching subjects and classes taught also indicated actual conditions in the schools. The subject group sizes varied because of the nature of the groupings of the specialist subjects. Sciences teachers comprised those who taught biology, physics and chemistry. Language teachers were divided into Indonesian, English and other foreign languages. Social science teachers taught civic education, geography, economics, and history. Many teachers were teaching in more than one grade and in this study, the majority of teachers taught in the final grade. In the Indonesia situation, grade III (year 12) is a crucial one, due to national final examinations. The results of passes in the national examinations are assumed to reflect school quality and therefore schools assign their best teachers for their grade III classes. Except for counsellors, most teachers were responsible for several classes in the same grade. In the state secondary school situation, in spite of the range of classes and grades, teacher mandatory work is 18 lesson hours per week (12.5 normal hours). In reality, 
some have heavier teaching duties especially in schools with limited numbers of teachers. In other instances, teachers also volunteer to teach extra hours, teaching in other schools or places (at English courses or as private teachers) in their own free time to maximise their incomes.

Most teachers who participated in the study were permanent teachers. Only one was non-permanent and another was a contract teacher. This permanency of the teaching positions indicates that state secondary schools located in the city are probably favourite workplaces for many teachers across the province.

Only 4 of the 53 participating teachers did not have undergraduate degrees. The Department of Education regulation for secondary school teachers stipulates that teachers must have an undergraduate degree, otherwise they would be asked to retire early. However, three of them were teaches of religion who found it difficult to pursue their B.Ed. degree because the nearest university was in Java, thousands of kilometres away. The reason why the fourth teacher had no degree was not known, although it is possible to complete a degree from the local university or from the distance learning Open University.

\subsubsection{School Committee members' background}

The basic information regarding 21 school committee members are presented in the Appendix 7.2. The majority (86\%) of the committee members were male and this reflected the male dominated culture in many social organisations in Lombok. Interestingly, two female committee members were teachers in other schools. 
The average age of school committee members was 47 years, perhaps reflecting the general active role of people in the middle age group. Interview data indicated that some of these people were highly regarded members of society (discussed later in Sub-Section 7.6).

More than one half of the committee members were serving as BP3 members (BP3 is a parent-teachers organisation tasked to collect funds from parents regularly towards school operational costs, see Sub-Section 2.3.4). Participation in BP3 activities provides useful experiences for committee work. Often, those with such experience are selected as the school committee members. On average, committee members in the study had served for more than a year.

The study data showed that school committee members were highly qualified. All had an undergraduate degree and three (14\%) had masters degrees. In general, only $4 \%$ of Indonesian population have higher degrees and this is usually lower in the eastern part of Indonesia such as in Lombok. It is probable that school committee members are selected partly on the basis of their educational qualifications. Undoubtedly, within the Indonesian context, the school committee reflects a well-regarded organisation with an elite section of the community over-represented.

The school committee was comprised of parents' representatives, school staff representatives, members of the community, government officials and alumni. However, there were others serving as school committee members as parents' representative, even after their children had graduated from the school. In these situations, the contributions of the individuals was considered valuable and still needed by the school. 


\subsubsection{State secondary school general situation in Mataram, Lombok}

All participating schools had more than 500 students. The schools were located in the capital city of the province and had been established for a long time compared to other schools on the same island. The oldest school in the area ("No. 1") had more than 1,000 students and was also regarded as the best in regard to academic outcomes of its students. In comparison, two other state secondary schools in the same city which were not involved in this study had fewer than 500 students and were only established in the last two years. These new schools had not yet graduated their students.

Based on government regulations, the maximum student number for each class was 40 . However, principals and teachers indicated that usually the class roll is higher, somewhere between 41 to 45 . This claim was confirmed from the site studies' schools. According to teachers and principals, class sizes of more than 40 was perceived as large, making it difficult to manage for effective teaching and learning.

State secondary school organisations in Mataram are the same as others around Indonesia. The principal who is chosen and elected by the mayor (walikota) is the superior officer of teachers and administrative staff in the school. The head of administrative staff in the school is stipulated also by the mayor with the main task of supporting school administration. The principal then selects four teachers, usually senior teaching staff, for vice-principal positions, in yearly periods. The vice principal is responsible for the following: curriculum affairs, students affairs, public relation affairs and infrastructural affairs. Organisational units such as science or language department are not established in Indonesian schools. In addition, the principal assigns teachers for certain 
responsibilities such as science laboratory, homeroom teacher and extra curricular activities.

The school academic year begins in July and ends in June of the following year and is divided into two semesters. At the secondary school level, grade I and II (year 10 and 11) students have similar teaching programs of 14 compulsory teaching subjects in a year with 42 lesson hours per week. Starting at grade III (year 12), students are grouped (usually based on their choices), into three specialties: natural sciences, social sciences and language. At this grade level they learn 10 compulsory teaching subjects in 44 lesson hours per week.

There is no compulsory zoning to enforce student attendance in a geographic area. Instead, students who have a good academic performance and wealthy socio-economic backgrounds are enrolled in schools of the parent's choice - schools they consider to be of higher standards. This means that some secondary schools are in a bargaining position to select students. Therefore, there is always a competition between state secondary schools. As a result, many private schools enrol students who are not accepted by state schools.

\subsection{Information regarding school based management}

This section explores issues relating to school based management, and the participants' views about their participation in SBM training.

Appendix 7.3 shows the range of information sources about SBM for each and includes principals, teachers and school committee members ranked respectively from higher influence to the lowest. The questionnaire survey revealed that all five principals obtained information directly from policy documents, which usually came to them via post either from the education 
district, provincial or central office. Four principals also obtained information from meetings they had in the education district office, which was usually a first level socialisation program to explain new government policy in education. Only one principal mentioned having received information from other sources. Because of their positions it seemed that principals therefore obtained the information from official channels.

The majority of teachers responded that their principals were seen as the source of information about SBM. The second source was the school meetings, where the principal delivered information to the teachers, usually on issues that the principal thought they should know. It is clear that the principals' understanding of SBM would also determine what teachers would or should know about SBM.

The education district office, other teachers, newspapers, SBM documents and others (education council, TV, Internet and radio) also gave teachers information regarding SBM, although the influences of these sources was less considerable than that of the principals. Of the 10 teachers who had read SBM documents, some were vice-principals, and some were also members of school committees, representing teaching staff. This means that principals again played crucial roles in ensuring that necessary documents were accessible to teachers. But they were also acting as gate keepers - only a few teachers were part of the principal's inner circle (such as the vice-principal and teachers who represent staff in school committee).

As for teachers, the majority of school committee members also reported that principals were their main sources of information about SBM. Sixteen of them mentioned that school meetings were an equal source of information. 
Again, it was usually the principals that invited committee members to attend meetings and to become members. School committee members' knowledge about SBM, like that of teachers, was highly influenced by the principals' understandings of SBM. A comment from a teacher unions' representative in the province reflected this:

I believe it should be the principal who is more knowledgeable about the school based management issue, and he discussed that within his school. However, if the principal has limited understanding about school autonomy, its structure and how to implement it, then it will not work (I-3). ${ }^{1}$

Only 9 out of 21 committee members mentioned having obtained information from SBM documents. This means that more than half of the committee members depended on information given by principals. From the interview data it was found that of the committee members who read documents, one was a member of the education council and three were teachers in other schools. Because SBM documents are legal bases for administering schools, they are important as primary sources of data for committee members. Again, it seems that access to the SBM documents (for the committee members) was via the principals.

The comments below by two committee members reflect some concerns about the information they got about SBM:

The need is for a deeper familiarisation on what school based management is about - particularly for the school committee members (Q-19). ${ }^{2}$

School based management is a new thing and it takes time to implement as intended. Conceptually and organisationally it needs several improvements in terms of its socialisation; and

\footnotetext{
1 "I” was the code for data from interview, and " 3 " was the number of the participants in my list.

2 “Q” refers to data from questionnaire, while the number was the order number of participants in my list
} 
also improvement and enhancement of school committee human resources $(\mathrm{Q} 20)$.

The comments above indicate that conventional ways to disseminate information about SBM were insufficient. The first respondent even stated that school committee members needed to know basic information about SBM. The term "familiarisation" implies something is not known and/or there is a need for a deeper knowledge. The second comment criticises the "socialisation" method for understanding SBM policy. This method involves advice given by principals during school meetings and the second respondent deemed this method to be unsatisfactorily. The respondent suggested that it should be used with other methods, more than once or regularly, and focus on the improvement of a wide range of committee members’ capacities.

On the adequacy of information about SBM policy, all principals felt that the information was sufficient. Seventeen or $81 \%$ of school committee members agreed. On the contrary, the majority of teachers were not sure or felt that information was not sufficient (Table 7.2).

Table 7.2 Participants' view about SBM policy they got

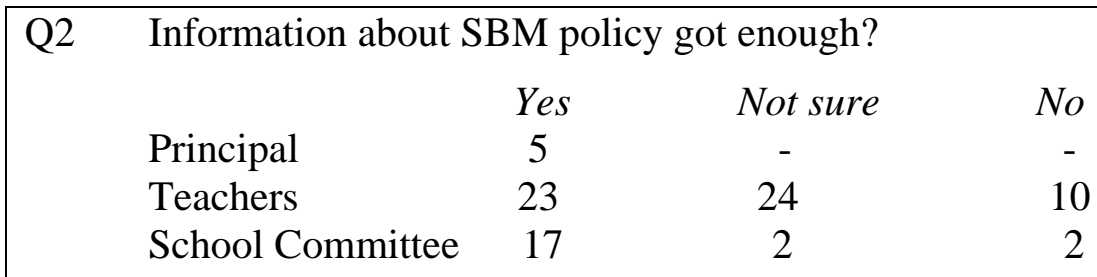

Although both teachers and school committee members obtained the same information from the same source (their principal), their views were different in terms of their understandings about SBM. This is interesting since the teachers spent considerably more time in school and had more contact with 
principals than committee members. It seems that what transpired in meetings for school committee members was different to that in teacher meetings. One explanation is that SBM was not a topic so readily discussed with teachers because it was the committee members who had management roles. An official from teacher unions confessed that for most teachers, ideas about SBM were

good and they want to implement it as well as possible, but their capability and even understanding about SBM is not fully informed (I-3).

Regarding SBM training, Table 7.3 shows the extent of involvement of school stakeholders in training activities. Three out of five principals participated in training sessions as compared with 5 (9\%) teachers and 6 (29\%) school committee members. Further, when asked about how long the training sessions were, there was no agreements about duration. These responses answers needed further examination however, since respondents were from the same schools and city and it would most likely be that they attended the same SBM training programs. Interestingly, the answers to the question about duration varied. For one principal and four school committee members it was 3 days. One teacher, 4 days. Another teacher, 5 days, another teacher, 6 days. For one principal, one school committee member and two teachers it was one week. For one school committee member it was 1-2 weeks and for one principal it was two weeks.

Table 7.3 Participation of SBM training

\begin{tabular}{|lcc}
\hline Q3 & Participated in SBM training? \\
& Yes & No \\
Principal & 3 & 2 \\
Teachers & 5 & 52 \\
School Committee & 6 & 15
\end{tabular}


The interview data revealed that only two of three principals actually attended SBM training. The other one attended a training session with a similar name, MPMBS (see Section 2.3.5) and this same principal wrongly mentioned the length of that training. Similarly, two other school committee members gave wrong information about the training days. Some of the teachers did not participate in SBM training in the city, but attended other in-service training that was organised by the central government. This included training on new curriculum, new teaching methods, or new evaluation methods and part of that program also dealt with information about SBM policy. This confusion was related to the policy being introduced by the central government simultaneously with several other new policies about education. Principals and the teachers therefore found themselves occupied with many new ideas regarding educational innovation, driven mainly from the Department of National Education in Jakarta. The new policy regarding a minimum threshold for students to graduate from secondary school was one example.

There were a few people in the state secondary schools who had firsthand accounts about the SBM policy as a result of participation in an in-service program. These training sessions were organised by education district offices, and presented by educational experts from the central, provincial and district offices all who had been trained at the national level. In Mataram, official information about SBM came in the form socialisation between participants, and also in training programs for principals and school committee members for all levels of education (I-7). The minimum exposure of school stakeholders involved in SBM training undoubtedly affected the policy intention and was 
likely to lead to a superficial implementation at the school level. One teacher, for instance, refers to this concern, as follows:

School based management ideas are good enough, however at the implementers' level there were big obstacles, resulting in gaps between understanding and implementation (Q-68).

Regarding the training session itself, one official from the district level explained his experience in organising the program, as follows:

In the training programme we invited principals and school committee chairman as a pair. However, from what I have seen, the principals tended to involve teachers [not the committee chairman or members], and this arrangement was unworkable. Their reason was because the committee member was busy or because it was easier to take teachers. Sometimes it was done this way so that they [school committee members] did not know about the issue (I-7).

This particular respondent was complaining about what appeared to be unfair treatment by the principal on the school committee. Furthermore, a teachers' union representative noted that both socialisation and training conducted in terms of SBM by the district government and education council never reached a point whereby change would occur. He was convinced that as:

[socialisation and training about SBM] was not frequent, not enough, in fact it was far from an effective and efficient method intended to spread ideas about SBM to school stakeholders (I$6)$.

In short, the quality of training was questioned and the training program itself was not available to all the state secondary schools stakeholders.

\subsection{Views and practices about devolved authority to the school}

This section presents data about school stakeholders' perspectives and practices regarding devolved authority to the school level. Subsequent subsections will analyse general issues and more detailed ones about the authority given to schools. The first sub-section discusses the kinds of authority exercised 
by schools. The later three sub-sections explain authority in terms of financial management, staff management and curriculum management.

\subsubsection{Authority devolved to school}

Appendix 7.4 shows the views of three respondent groups regarding the authority they think that schools can exercise. Although the three groups responded slightly differently, they agreed that a school development plan, managing school facilities and budget allocation and management are the three key roles that should be transferred to schools. However as found from site studies, Indonesian state secondary schools had already exercised these kinds of de facto authority for years. In this sense, it was not a new thing for school stakeholders. However SBM policy made this authority more salient, requiring all schools to use strategic management tools (such as SWOT analysis to make their own vision and mission statements), plan for the school's future, and identify resources.

As a group, the principals were in favour of authority transfer to schools; generally they wanted all authority to be devolved to site levels. With regard to teacher training, only three of the principals thought it could be organised in schools and only two out of 5 principals felt that curriculum management should be authorised by the school. In the previous and present systems government regulation stated that only the central office had the responsibility for curriculum issues. The following comment from three principals reflected this concern:

In managing the school, with SBM policy, it was given much flexibility to develop itself and that included curriculum management, based on regulation of course, but it was not unlimited freedom. We also have flexibility in instruction and its management and source of fund (I-8). 
The basic foundation of SBM in the decentralisation era is school autonomy and participatory decision making which involves all school stakeholders (I-16).

According to SBM, school is given the authority to develop themselves in order to compete with their own potential (I-20).

These statements from principals show their knowledge and awareness about the issue, but this awareness did not emerge from teachers or school committee members. For principals, SBM can be used to legitimate extra school activities such as an English day programme (compulsory English speaking in school for a whole day), building refurbishment and improving student discipline. Those efforts regarded as innovation that make the school look better, and will make their school impress by the public.

Teachers on the whole felt that the authority for making decisions regarding maintenance, budget, school plan, student and curriculum ought to be devolved to schools. Less than half the teachers felt that schools should have authority for staff management and teacher training. It appears that many teachers did not think that schools would give them better service than the present district-centralised system.

About one half of the school committee members felt that managing students, generating other resources and teacher training should be devolved to schools. By contrast, committee members did not see schools managing curriculum and staff. These views were similar to the views of other stakeholders; and were indicative of their belief in a limited school capacity.

Several comments from the questionnaire and interview data revealed some of these issues. Two school supervisors, for instance, explained what they saw happening in the schools: 
One of the real obstacles in schools and for school principals particularly, is that they don't fully understand the changing system. As a result, in many schools we could find many principals who are not used to school autonomy as an opportunity. This is because under the previous system the practice was to wait for technical instruction from our superior officers. Furthermore, there was little training and preparations for this to occur (I-1).

In terms of substantive change, I don't see any significant things happening at school... This is because the changes involve a way of thinking and attitude, which are not simple (I2).

One teacher had also had similar view about what occurred at the school level:

Institutionally I think our school is not ready to take its' own action as mandated on the SBM system. In addition we also have what I call 'centralisation syndrome' which means we don't have courage to take any action without the superior officer at district level knowing about the content of decision. As far as I know, there is no principal who takes such actions which is his legitimate authority without obtaining agreement from education district office (I-13).

These two explanations above indicate who the participants believe is the real authority on education in the autonomy era. It is not surprising that the principals were the individuals who most fully understood this situation because they were selected by the bureaucratic process. If they made unfavourable decisions without consultation with their superior, these could jeopardise their careers. So it was prudent to simply follow the traditional means of decisionmaking.

On the other hand, there was an explanation from the teacher union representative about this situation,

principals and teachers felt that in fact in this autonomy, what really is happening now was half-hearted autonomy....school superior officers indeed were not ready to see the school as being independent (I-6). 
However, when an official from an education district office was asked about authority that could be executed by schools, his response was as follows:

Devolved authority is a good thing, but it can become a really big problem when directed by an incompetent principal. It can destroy the school. However, if the principal is good, the school can make great achievements (I-7).

This officer seemed to think that the important component for SBM was a good school principal. Schools would not be ready to manage themselves unless they had a good principal. This respondent's perspective also suggested that devolving power did not necessarily result in a competent principal.

Another issue related to the perception by principals and superior officers about what constituted a good school. A school supervisor describes it as follows:

I really understand that most principals perceived the success of their leadership was not based on intangible things, something ideal, such as managing the school to become more independent. But they perceived physical appearance such as refurbishment of school buildings, new painting of fence and fine-looking school yard as the indicator of school achievement (I-1).

A different view was expressed by a teacher, who saw that one impact of the implementation of SBM policy was reducing the uniformity that had usually been practiced during the previous regime:

If there is no uniformity about regulations, this would result in the community complaining, especially in terms of new student entrance requirements (Q-65).

The above comments are undoubtedly indicative of the extent of influence of the previously centralised system. The comment indicates that some teachers regard change as likely to pose risks to their careers. It cannot be denied that devolved authority to manage dissimilar problems and priorities is likely to pose different 
challenges for different schools. In the Indonesian situation, student admission to certain public school has the potential to become big news. This is because of the way good quality schools are perceived and competition for places in schools is high. Further, in state secondary schools nowadays, entrance is not only based on academic performance but also on the willingness of parents to pay funds to the school.

Interviews with groups of respondents revealed that student admission was most critical because strategic manoeuvres by each party ensured maximum influence to achieve their intentions. This is because state secondary schools were perceived as directly responsible for achieving a better future for students. As a result, a school's authority, particularly the principals', in terms of student admission is marginalised. One state secondary school has to follow community pressure to accept students from a nearby school as one principal illustrated:

We plan to accept four parallel classes; each class consisting of 40 students. But, people who live close by school, the subdistrict government official forces us to accept more, and so in the end we have six classes which contain of 48 students per class, which is certainly too many (I-8).

For other schools, the party who usually persuades the school to increase the number of student admissions is superior officers (the mayor and education district office):

Our school has to add one class (40 students), because they demanded that. We can do nothing about that even when we explain we don't have enough class rooms for that (I-20).

As a principal who originally was a science teacher, I feel ashamed. This is because we use the science laboratory as a regular class room. We just follow orders to increase new student numbers (I-16). 
Moreover beside this there are also personal requests to the principal, usually from officials in the education district office, to enrol certain students.

Undoubtedly this results in conflicts of interest. One principal noted:

Student admission is a sensitive practice and at times intervention occurs from outside.. It is because students who do not pass the test can actually be accepted because they are the child of an important government official. This is unfair to others, and makes me have sleeping problems.... Sometimes I can refuse one or two but as a result my superior officer gets really angry with me (I-20).

Another principal, however, welcomed the request:

Because we have specific instruction from the mayor which states 'children who live close to school shouldn't be rejected as students.....There was also a new student enrolled in our school, the father was an important bureaucrat and had recently transferred to this city.... the district education office gave me an unofficial request to admit the student, so I just put him into our school. It seems everybody was happy (I-12).

What this all implies is that student admissions are an indicator of authority and one way in which the degree of school autonomy can be measured.

\subsubsection{Financial management authority}

With regard to devolved authority relating to finances, the view of the three groups of school stakeholders appeared to be the same (Appendix 7.5). It seems the groups consistently held similar views regarding priority and the nature of financial authority.

For a long time, all stakeholders knew that one of a school's main tasks was planning the school budget. For stakeholders, this was a priority task. As public institutions, state schools were regularly provided with funds from the central government through a block grant to the district government for salaries and operational costs (recurrent budget). Yet, stakeholders' ranked the 
management of government funds second, compared to managing funds from parents, which was ranked first. This ranking supports the view that money from parents was seen as more significant for schools. Further, unlike funds from the government which is often outside their influence in terms of the amount and timing of receipt, the money from parents comes on a regular basis (monthly), and is more flexible in terms of spending. Parental funds are decided by schools and remain in the hands of the schools. Schools use these funds to meet their needs, because funds for operational costs from the government are very limited even for the school's basic expenses such as electricity, water, telephone bill and paper. For the school staff the funds are a source of additional income for them as well, depending upon their hours of teaching and position.

When respondents were asked about changing budget allocations, there appeared to be little support for this. Participants felt that schools were restricted by government regulation, particularly for funds from the government. The idea of managing teachers' salaries, giving the school the right to decide their salaries and to deliver these regularly, was not considered favourably. Few respondents supported this kind of devolved financial authority. Participants felt that managing teachers' salaries is a difficult task and school administrations do not has the capacity satisfactorily to handle it.

Data from interviews were consistent with the questionnaire. Two significant issues emerged in terms of financial management in school: the funds from the government and from the parents. But these two funds had different sources and were treated differently.

Dealing with the routine fund that incorporated the yearly school budget was mainly the authority and responsibility of the principal. Deliberations 
regarding it were conducted mostly in secret, from it's planning to reporting stages, even after the introduction of the SBM policy. The following comment from a teacher typifies the common practice that happened in many schools:

The routine fund comes from the government; we do not know how much it is. According to the principal, the school committee members and the teachers are not allowed to know about it. In short, most principals have an attitude that they do not want to share such information. Only two people have access to it [the principal and school treasurer]. As a result we do not know about the routine fund contribution to the school budget, it could be that some bills are paid twice from two sources [routine fund and parent's money] (I-13).

A school committee member who had been experienced as a member of BP3 in two consecutive periods (about 6 years) expressed a similar view:

Regarding the routine fund, we are not involved at all. The routine fund is managed by the principal. But the school committee may be invited to talk about it and make the decision (I-11).

The above comments indicate who is significantly in control of the school budget, particularly the routine fund from the district government.

In the autonomy era, contrary to the previous system where funding was directly given to the school from central office, state secondary schools had to deal with considerable bureaucratic red tape at the mayor's office in order to obtain non-salary funds (to meet school operational costs). It often did not come in the full amount and was delayed. That is one reason why the schools relied on money from parents.

With regards to the fund that came from parents, the budgeting process was somewhat different. This is because at the beginning many parties were involved and shared information. Usually the budget planning process was started at the end of academic year (June). The draft was mainly developed by 
the principal and then given to a delegated teacher. Undoubtedly, the budget proposal had more than one draft. The following comment from a teacher (I-21) illustrates this:

Researcher (R): How is the school budget proposed to the committee?

Participant (P): The school proposes the budget to the committee and I make the budget plan for this academic year. Actually I made ten budget plans over one week.

R: Why do you have to make that many plans?

$\mathrm{P}$ : The ten budget plans were shown to the principal, and then he with the committee choose and decide which one is appropriate.

$\mathrm{R}$ : What are the differences between those ten budget plans?

P: Basically it is the amount of monthly school fee that has to be paid by parents. The principal and the committee select which one is the best, and then the committee will release this to the parents in the committee general meeting. Certainly the meeting is the most risky one, because it could be the parents don't agree.... After the budget officially is accepted, we disseminate the details to teachers and administration staff. This ensures they know about the amount of money they will receive and are aware of the kind of school programmes that are funded from the parents' money.

The principal (I-16) from another state secondary school explains the process slightly differently as follows:

The budget plan was developed only by the principal. I made a draft then we discussed it in a meeting with teachers and administration staff, collected comments and made revisions. After that we asked the school committee members to brainstorm about the programmes that were to be funded by the budget.. The committee were always curious about the program that we planned, and asked, why is there urgency for this? This then led to another revision of the budget plan and agreement reached. Early in the academic year we print the budget plan and distribute it to parents at the annual school meeting. Subsequently, there was bargaining with parents [about amount of school fee]. 
Those two quotations indicate that the budget planning process with the parents' money was more transparent and democratic than the government fund, certainly as far as these respondents were concerned.

In contrast, some parents considered the method of developing the school budget manipulative. Only parents of new students were invited, the meeting agenda had already been drawn up by the school, it followed its interests, and there was little time provided for understanding or questioning it. Many believed that parents were driven by the school to accept the plan without listening to their concerns. This practice is similar to what happened with the POMG and the BP3 (see sub-section 2.3.3 and 2.3.4). In addition, inflation accumulation since the Asian financial crisis of 1997 and the perception that state schools are of superior quality, resulted in 'stipulated' school fees which became a burden to the average parents' financial situation.

Two state secondary schools which volunteered details of their school budget documents, and these revealed interesting information (a sample of typical state secondary school budgets is shown in Appendix 6). Firstly, in terms of total amount, parents' money collected by the school in a year was much greater than the operational fund from the government. According to Supriadi's (2003) study, state secondary schools are regularly given around 30 million rupiahs (equivalent to US\$ 3,000) for operational costs from the government annually. However the two site study schools could collect ten to fifteen times that amount. Secondly, $40 \%$ of the fund was allocated to school staffs (which already had regular salary as civil servants) based on their position (principal, vice-principals, administration staff, teachers); an additional amount of money also based on teachers' teaching time and extra responsibility (such as home- 
room teachers, teachers responsible for extracurricular activities, and teachers who were assistant to vice-principals). Thirty percent of the fund was allocated for non-permanent staff (non-civil servants) and an additional fund to cover school over-head costs; around $20 \%$ of the fund is used to support teaching and learning processes. Thirdly, what the school indicated about their innovative programmes was under-funded and unsustainable. This is because many programmes that were listed in the budget plan were in the main not supported with enough funding or had inadequate capacity to fulfil the programme, its intention was more to show that the school had a wonderful plan.

From a legal perspective, public secondary schools that collect funds from parents don't have enough legislation and regulation to back up their actions. Although in the budget plan stated by the education district office a 'school levy' regulation existed, and a circular from the mayor commented on its use this did not make it legitimate. Moreover, the school committee also stipulated that an additional amount of money had to be contributed by parents regularly, which was 55\% higher than the 'school levy' stipulated by the head of district education office. However, nobody questioned this kind of activity school stakeholders such as principals, teachers, parents, and the community regarded it as something ordinary and were accustomed to it.

Undoubtedly, this kind of fund is very flexible for the school in terms of spending, which is not a characteristic of the routine fund. A principal explained it as follows:

As long as we talk about our request and give clear and rational argument for that to the parents' representative, they will provide authorization. Changing allocation of the budget should be informed and accountable. So, changing school budget allocations is permitted as long as they know about it (I-16). 
On the one hand, funds from parents are becoming a significant contribution towards school operational costs (non-salary budget). On the other hand, this did not result in a bigger bargaining position for parents or their representatives on the school committee. A school supervisor explained this issue as follows:

Some principals don't want to be controlled at all by the school committee. However, it depends on each individual. Although the principal in some schools may have that attitude, in terms of financial accountability he must make it very clear. It was not only implementing what the principal wants......at least before the money is spent there was an agreement from the committee (I-2).

One school tried to involve as many parties as possible in the school budgeting process for all funds. The principal, who has a postgraduate degree from an overseas university used different practices to empower teachers in relation to the school budget. The following comment illustrates this:

For transparency in our school, the practice at the beginning of the academic year was to appoint a teacher responsible for a certain program.. There was a teacher responsible for religious instruction, increasing academic performance program, vocational activity, information technology, sport activity, (etc.) ... outside the vice-principals who have their own program. Then other teachers were grouped to each program, to make their own budget plan together. After that, all plans were gathered, related to the available funds for that year, and then a spreadsheet was developed. One example ... for the sport activity the teacher he will know where the money to finance sporting activity will come from; it could be from the management operational assistance fund ... some million rupiahs [routine fund], and from BP3 [parents] another million rupiahs etc...Each teacher who had such responsibility knew the amount of his/her budget in a year including its source. As the principal I monitor what is happening (I-8).

One teacher who came from the same school was interviewed and confirmed the principal's explanation (I-22). Interviews and observations in other schools revealed, however, that such practice was not common. 


\subsubsection{Authority in staff management}

Unlike the results discussed in previous sub-sections, participants' responded differently regarding the matter of authority in staff management. It seemed that each group had a different priority regarding this issue. Data from questionnaires and interviews indicated a number of complex issues surrounding devolved authority on staff management.

As a group, the principals felt that schools should be responsible for selecting and recruiting administrative staff (Appendix 7.6). Their attitude shows that the principal's job as school administrator depends on the administration staff who were often seen as inadequately trained. Unlike teachers who have a university education, nearly all administrative staff were secondary school graduates. Principals found their close supervision of the day-to-day activities of administrators was not beneficial. They felt that the administrative staff do not provide the kind of adequate performance required, which is generally consistent with how others think about the public sectors (see for example Rohdewohld, 2003; Filmer and Lindauer, 2001). The teachers' response revealed a similar perspective. Only school committee members who were not involved in daily school activities had a different view. Eight out of 21 school committee members agreed with such devolved authority.

Respondent groups felt that the evaluation of teachers' performance should be a devolved authority. Principals already exercised annual performance assessment for the teacher as a government employee. But this evaluation was administrative and too general. The teacher's performance evaluation in teaching and learning was still conducted by the district office, but this exercise was basically a paper exercise, and did not measure the effectiveness of teachers' 
work (see Nielsen, 2003). So the idea that schools appraise teachers was not only supported by principals, but also by teachers and school committee members. It seemed that principals were confident about their own abilities to undertake performance evaluation of teachers.

However for the teachers, their professional development was their priority (42 out of 57 were in favour). This was not a coincidence since most inservice training was organised and conducted by their superior officers who were either education district officers, provincial officers or officers from central office. From the teachers' point of view, professional development sessions generally made them feel disempowered (see for instance Thair and Treagust, 2003). To them, the professional development activities use one-way communication, with the main purpose being to socialise them into new government policy or educational innovation. A representative from the teachers union argues that this is why it does not empower teachers:

The administrative purpose is the essential purpose. .... it is just to spend the money. They don't think some kind of need analysis is required, which would demonstrate different needs for different teachers. Experienced biology teachers, for example, their need for professional development is different from novice teachers. They don't care about it, that's why the results are far from optimal (I-3).

On the other hand, teachers who attend professional development training had free time from their teaching. Furthermore, they got additional money just by attended the training and sometimes an opportunity to see other places. Unsurprisingly, for training in other provinces or in the capital city, teachers were competing to get the chance (Mulyana, 2003, personal communication).

One promise that came with the implementation of the SBM policy was that professional development for teachers could be conducted as they wanted 
(see sub-section 5.2.1). However, there appeared to be no changing practice regarding this issue. As indicated in this comment from a school supervisor, change at the school level was not happening:

Any kind of previous professional development efforts for teachers at district level like PKG [pemantapan kerja guru, the strengthening of teachers' work] or MGMP [musyawarah guru mata pelajaran, the consultation of subject teachers] organised by bureaucrats didn't work very well. Then we came to the idea, why don't we give money directly to the teachers and let them make their own program for professional development at school level. Unfortunately, this idea was not supported by a group of principals, they were afraid. They even influenced the education district office to ensure this did not happen, and suggested it would be best to implement another year... a buying time strategy (I-2).

The ideas of recruiting principals and teachers at the school level was not supported however by all groups of respondents. Only one out of five principals, one school committee members from 21 participants, and 18 out of 57 teachers agreed that schools should select their own principals. These small numbers demonstrate that delegating this kind of authority may be far too ambitious at this time. These views also parallel responses about schools recruiting their own teaching staff. Teachers, in particular, considered this to be a low priority. A comment from a teacher reflected this view:

At this time only half-policy about SBM is really implemented, which means only some particular and trivial things get done. Far too difficult for it to include exercising authority about principal selection, I think that's very hard (I-15).

Becoming a principal in Indonesia's state secondary schools is regarded, as was mentioned earlier, as a privilege by many people (Purwono, 2004, personal communication). The principal is selected through a very routines bureaucratic selection process between senior teachers. Once a person is selected, it is unlikely s/he will return to work as a teacher in the future. This 
means that the system will maintain s/he to continue as a member of this exclusive group with 'powers' in the education sector. Principals also have an opportunity to obtain more prestigious positions later. So it is not surprising to see the principal's perspective appearing to support their own interest.

A teacher who opposes principal recruitment by schools explains his concerns as follows:

I am afraid, that if we choose our own principal, then the person, who emerges, based on popular vote, may be a dictator or may be obsessed with the need for respect. This will result in very bad impacts on the school (Q-65).

A school committee member also believes that the real implication of selecting principal by school committee will create a worse situation:

I think that will be more risky to the school. How do the committee members know which principal candidates is better? Nowadays it should be acknowledged that we are faced with nepotism, when the committee has a right to principal selection the level of nepotism will be higher (I-11).

These two perspectives implied that a 'democratic election' to recruit principals by school stakeholder was not advisable either. A teacher and a school committee member thought the worse case scenario involved a lack of capacity to judge possible principal candidate which can result in favouritism based on nepotism. In another response, it was suggested that teachers generally were inadequate to become principals. An official at district level supported this view:

At this time, we can choose someone to become principal from eligible teachers but most of them are unqualified. There are few who are qualified, they may be too young and his/her rank position is not sufficient. Also we are not ready for a young person to become principal. In short, still lots of obstacles (I-7).

However, by contrast, another teacher supported the idea of principal selection by the school. But he believed that teachers should have this authority: 
I think school committee members do not know much about the performance of each teacher. Only teachers at the school who are acknowledgeable about a particular teacher if s/he is suitable, capable or smart enough to become a principal. The teachers should be given rights to choose their own principal (I21).

He believed that teachers know more than school committee members, and that this should be a leverage to use in gaining what teachers want.

Others responded differently - some believed that the best way was by a clear and transparent mechanism. Comments from two education council members illustrate this as follows:

In the previous system, the appointment of principal was merely based on like and dislike. A new principal can be completely unaccustomed to our school situation. At this time we want at least school stakeholders to be asked about who they want... if they have a candidate, or the authority can be given some alternatives before appointment (I-4).

Principal selection at school level obviously will draw conflict between school, school committee, district education office and of course the mayor. The first thing that has to be established is a mechanism for that, it should be open and fair for every party (I-23).

With regards to teachers' recruitment at school level several issues were also identified. All secondary schools which participated in this study reported that currently some teachers were needed to teach particular subjects, although it would probably be a long wait before appointments were made. A principal explains this situation as follow:

From the school side, we have a responsibility to ask the district education district for some teachers. A couple of days ago I asked for a qualified teacher....just move him to our school. But, the office answer was that we will consider that later, just use who is already eligible (I-20).

Because it was difficult to attract teachers via the district government, the school itself selected non-permanent teaching staff. This response from a teacher illustrates an experience which others have had: 
Usually the vice-principal for curriculum affairs tells the principals that there is no teacher for specific subject matter or that a particular teacher has a heavy teaching job. Then they look for a non-permanent teacher, they select from available candidates who meet requirements. The principal and one teacher decided which one passed the selection (I-15).

In contrast, for the appointment of a permanent teacher (civil servant teacher) the schools did not have any choice except to receive who was appointed. So the notion that schools could select their own permanent teachers was an appealing idea for principals and teachers. One principal who was excited with this possibility noted that the:

Principal should be given authority to appoint and fire permanent teachers and administration staff $(\mathrm{Q}-22)$.

Teachers also supported the idea because they found that the performance of permanent teachers was not always satisfactory. Three permanent teachers from three different secondary schools shared their experience regarding their counterparts:

Regarding teacher's recruitment, schools can only take it for granted and cannot select and refuse who is coming to our school. This is our weakness, we do nothing about it. There are some teachers who have big problem here, we cannot reject or fire them because they are government employees who hold an official appointment letter from the government (I-19).

We have difficulty in dealing with teachers who sometimes come late to the class or their teaching work is inadequate. They were permanent teachers and it was difficult to fix (I-15).

I always find it frustrating when I have to manage students in relation to teacher absence. That is our classic problem. I only can give suggestions to the principal regarding that teacher's performance, but mostly there was no good solution (I-13).

As a result, permanent teacher selection was viewed as a key task that many wanted devolved to the school level. This was because the school could have greater flexibility to manage permanent teachers and minimise bad performance. 
Another sensitive issue that emerged more openly in Indonesia during the autonomy era related to diversity. For example, one educator wrote:

Enhancing nationalism, abolish preference which is based on race, culture, religion, ethnicity/local identity (Q-64).

This view has become more accepted and was practiced at the district level across Indonesia, in terms of new government employee recruitment or appointments to strategic positions (see for example Sagala, 2003; Soewartoyo, 2002). The respondents undoubtedly perceived that if the school was given the power to recruit principals and teachers, then some preferences were likely to be shown. Like other areas in Indonesia, Lombok has people from diverse community backgrounds within its education sector and one group (usually the local ethnicity) dominant in its bureaucracy. Other groups who are minorities in the local population (but usually the majority in their place of origin, such as Javanese in Java) often do not really enjoy such privileges.

A school supervisor who came from another island also indicated the possibility of this becoming an issue:

I have a concern that the employee recruitment mode in the future may be based not on the quality of candidates, but on their identity, using the authority opportunity that is given by autonomy. My worry is that there is something sad in this regional autonomy policy that a person who governs education, because of the autonomy spirit, has to be governed by local people. I think this one is not a possibility anymore. It is a reality (I-1).

A teacher who was born in Lombok also had a similar perspective:

I hate to see preferences such as ones based on locality or religion for a reason, they hide themselves from incapability. It is not fair and also it will jeopardize the future of this island (I15). 
However, two respondents who had years of experience in government positions acknowledged the practice could happen and suggested solutions for that. An official from the education district office argued as follows:

Let's see what happened in Java. Central Javanese civil servants cannot get a position if they worked in East Java, and vice versa. Even in Bali, for a long time that was the common practice. I think in Lombok the situation is different, we welcome the others. Of course with the autonomy, there were people who use this opportunity. It is something that cannot be avoided, so we have to establish a regulation about that (I-7).

A school committee member who worked as a high ranking official on a development planning board at provincial level gave a similar view:

Lombok people are more accommodating than others, compared to Bali for instance. We don't have a problem with other ethnic groups who hold strategic position in the local government. I know that the situation is slightly changing at this time, that's why we need a fair meritocratic system for that (I14).

\subsubsection{Authority in curriculum management}

Appendix 7.7 shows participants' responses about the 'core business' of schools - curriculum management. Only teachers, amongst the respondent groups favoured devolved authority to schools for curriculum management. It seems that teachers are ready to implement it without hesitation.

From the principals' point of view, teaching methods, and curriculum development along with textbook choice are favoured areas for devolved authority. There seemed to be less support for other teaching materials and the graduation examination. These choices certainly reflect the position of principals more than education officials who tend to stick to current regulations. For instance, on the one hand, principals favour being able to decide which textbooks should be used in school, but on the other hand other they do not support control 
new other teaching materials. This is because any textbook that is used in school has to be short-listed through a central government selection process, but other teaching materials mainly come from teachers' efforts to enrich students' learning.

Unlike principals, school committee members chose other teaching materials as their first choice for devolved authority. However their perceptions tended to be different to those of teachers and principals. A comment from a school committee member is indicative of the difference:

Choices of curriculum, book and other teaching materials should be based on national standards, not devolved authority (Q-17).

For principals and school committee members, the idea that schools should create their own graduation examinations received the lowest priority. But for each group it was based on different reasons. The principals considered that the MoNE should continue to conduct the final examination. This process involved the central government having veto over planning, implementation and establishing passing standards to be achieved by students. For committee members, quality and state certification tended to be their main motives as most of them were higher educated parents who wanted their children to pursue higher education.

Other issues raised by a teacher reflected some of the wider concerns:

There needs to be a streamlining of teaching subjects and curriculum loads. School infrastructure needs upgrading to support teaching and learning in terms of school based management (Q-64).

The points above are classic complaints by teachers about Indonesia's school curriculum. Teachers have, for some time, felt that there are too many subjects 
to teach to students and an over-whelming syllabus in each subject. In addition, teachers see that there was having been no changing practice about this, especially with regard to the curriculum target which has to be completely delivered to students in an academic year. One teacher complained as follows:

The principal said we had come to the end of the curriculum target. There were no such things like mastery learning, he never thought about it. The curriculum targets were to be $100 \%$ delivered, if there was a teacher who wrote $75 \%$ or $80 \%$, this became a big question (I-13).

Another teacher sharing his experience and noted that:

The principal and school supervisor always had concerns about the curriculum target and its level of absorbability. Curriculum target had to be $100 \%$ delivered, and its level of absorbability reach the same point. I had a heated discussion with a supervisor regarding this, but the answer is very clear, we have to follow the establishment (I-17).

Those views reflect the facts that for teachers, having authority in curriculum management is positive for them. They hoped that one of the outcomes of the transfer of this authority would be to resolve such concerns. It is a hope based on the perception that school based management is the catalyst for innovation in education for all Indonesian schools.

In order to nurture the schools autonomy to plan and execute their programme to improve educational quality, the MoNE introduced the MPMBS programme (see sub-section 2.3.5). Three out of the 5 schools involved in this study were selected to implement this programme. One of the objectives of the MPMBS for the schools was to incorporate all educational innovation that had been given by the central office (such as contextual teaching and learning, and portfolio assessment) into their own programme to improve student achievement. 
However, two schools who participated stated that there were some difficulties in the implementation of the program. One school reported that the fund termed BOMM (bantuan operasional manajemen mutu, operational assistance for quality management) from the MoNE could not be used fully. This was because the funds earmarked as 'seed money' have to be given as “kickbacks" (one source said it’s nearly 35\% of the total fund) to buy laboratory equipment and materials that schools already had. The following comments from a teacher discuss this:

We have to buy a list of laboratory materials for a certain amount. A month later the materials came. On the other hand that fund was not intended to buy such things, that made the budget be squeezed and some programs were eliminated (I21).

Another teacher responded that a big proportion of the BOMM funding was to finance a programme that provided extra teaching time to students to assist them to pass the national final examination. He expressed the following:

Extra teaching for other grades was present [beside grade III]. But, to buy teaching materials, such as books, was not happening. Enrichment for students through extra teaching is routinely performed by the school long before the MPMBS program is implemented; we only added nominal honorarium for teacher because of that (I-15).

It seems that the MPMBS fund's role is to assist schools to continue practising their usual programmes. This implies that the school capability to plan, to innovate in curriculum management as desired by the MoNE, was far from satisfactory. 


\subsection{Parents and community involvement}

This section will discuss participants' perceptions and the practices of parents and community involvement in schools. Appendix 7.8 outlines responses of three groups of school stakeholder in this matter.

All groups appeared to think that the role of parents and community in relation to schools was mainly to supply and maintain facilities. These perceptions were reflected in some of the comments from the interview sessions with the school committee members, teachers and principals respectively:

The main task of the school committee is to help in terms of physical things...for instance that kind of development that is not funded by the government, then it is for the committee to act (I-5).

School committee involvement is mainly in terms of supplying physical things, such as facilities that school needed (I-19).

In terms of planning, to make school buildings some fund comes from the government, then with the committee's help two or three buildings are developed, because the school committee has a responsibility to collect funds from other sources (I-8).

Unsurprisingly, responses from the questionnaire were quite consistent with these views. All groups of respondents chose involvement in supplying school resources as the main way parents and the community could participate in school life. This was a long-standing view of the parents most appropriate role. The introduction of the SBM policy did not make a difference, parents and other community representatives than parents were still positioned on the periphery as providers of unlimited resources for schools. In a immediately, the resources become the monthly school fee that parents had to pay (as explained in subsection 7.4.2). 
Four out of five principals responded that parents and the community representatives have to be included in managing funds that are collected from parents. The main reason for this was that the money can only be spent based on permission from parents' representatives. A similar number of principals were also in favour with the involvement of the community in term of maintaining school facilities. Sharing responsibilities for school buildings would be welcomed by principals where government support was limited. It would increase the sense of belonging by the community and also be a source of cheap labour to complete jobs that educators lack expertise in. Three principals supported the view that parents and community members should be sharing their knowledge and skills in teaching and learning. The principals acknowledged that there was plenty of experience that people outside school could be contributing to students' understanding. However, for principals parental involvement in extra-curricular and out-of-school activities was not favoured. The principals realized most of these activities were outside school and therefore difficult to control, so they believed they were best undertaken by teachers.

Generally, for the groups of teachers and the school committee members, their responses were the same. More than half of both groups supported the involvement of the community as a labour force to maintain school property. The main reason for this, as with principals' was to tighten the relationship between the school and the community. In particular, 11 out of 21 school committee members supported the idea of involving themselves in managing school funds coming from their constituency. The rest believed the school was capable enough to administer the funds. The respondents indicated that the school committee members did not know much about school financial issues. 
Furthermore, the school seemed to enjoy this position, at a time when funds from parents were more significant than those from the government (discussed in section 7.4). A group of teachers and school committee members were in support of other community involvement approaches, but they were fewer than $50 \%$. From the teachers' perspective, for instance, the community did not have enough capacity to engage in teaching. All groups of respondents seem to position the schools as more knowledgeable, therefore community involvement was welcome only when the school needed this and in a limited way.

The data from interviews also revealed similar findings. In addition, the data provided further explanations about several issues, in terms of relationships and methods of involvement. First, respondents were asked about their perspectives regarding four roles and seven functions of the school committee as stated in the MoNE decree (see subsection 5.2.3 and Appendix 3). Most respondents believed that these were difficult to implement, and only one role and one function specifically were always mentioned. These were the committee's role as a supporting agency (role number 2) and the committee's function to collect money from the parents (function number 6).

Second, some respondents provided different examples that needed parents or community involvement. Several responses from the participants revealed that in most cases the school invited other stakeholders to become involved in terms of:

- $\quad$ students who had difficulty in learning or behaviour (I-13, I-19)

- requesting additional funds for building refurbishment (I-23)

- finding a resolution with the local community because school buildings separated by public path makes is difficult for school to monitor students (I-13) 
- establishing a new student admission figure so as not to overload the school (I-22)

Overall, these examples show that parents and the community are predominantly involved only by a request from the school.

A school supervisor argued that this situation occurred because the school itself was not open to others' ideas about education,

I believe there are many people who want to contribute and be involved in school in terms of wanting to improve educational implementation and quality. Their obstacles are they don't have any access to the school or the committee and rigidity of school organisation structure which usually makes them feel subordinate and they don't like it very much (I-2).

It is expected that community involvement could bring positive contributions (Bray, 2000), especially in the reform era where opportunities should be more available. One participant concluded that:

Involvement methods in terms of thinking, input, and then attention are mostly needed by the school. Those are more important than money, I think. The money is important, but mainly we are not measuring its contribution in terms of the achievement. In other words, the school is supposed to be more open for others because they already drain other resources (I-1).

\subsection{School Committee}

The emergence of a new body at the school level will undoubtedly make adjustments, adaptations and may even contribute to some innovations. This section deals with the dynamics of the school committee issue at the school level. Participant responses from the questionnaires and interviews provided colourful descriptions about this new body at the school level.

Appendix 7.9 summarises all participants' responses to the five questions about the school committee. The response to the first question (Q9a) was similar for all groups - more than half perceived that the school committee was not an 
independent body. The response was really interesting, particularly from principals who were the first in the school who knew about the decree that stated that the committee is an independent body. It seemed that the majority of participants' responses could be based on the reality they actually experienced about the school committee. They saw that the committee was not independent. Instead they perceived the committee as being dependent on the school. That the committee was not considered an independent body, reflected the power relations that existed in most state secondary schools. An illustration from an educator indicated the reason for this:

In all schools, the committee is highly dependent on the school's host in terms of financing their existence; one example ... conducting a meeting and purchase of food ... the committee cannot do it. This is because the committee does not have authority in terms of funding (I-6).

The majority of participants responded that membership on the committee was not decided by the principals (Q9b). Instead, the recruitment method used to select individuals to be school committee members, while facilitated officially by the school was decided by others. Around $78 \%$ of teachers as well as $86 \%$ of committee members also responded that the principals did not directly decide on the committee composition. However, participants' responses from the interviews reveal several issues regarding committee formation and methods of recruitment.

Firstly, all schools elected their own school committee members at the annual school meting. Parents, mostly of new students, were invited and the meeting's agenda was to form a school committee and at the same time to decide about the amount of the school fee. The meeting itself, however, is fully 
controlled by the principal (see sub-section 7.4.2). Parents' participation was somewhat limited:

Researcher: Were all parents coming to the meeting?

Participant: It never happened. All over Indonesia never do all parents come to the meeting. As a maximum there are around 20 to $40 \%$ [parents of new student] (I-14).

From this small proportion who came, usually a few would speak about their concerns in the limited time available. A school committee member noted:

The school committee in our school was directly appointed, and then the principal made a decree to stipulate that. The first thing was a plenary meeting with all parents, which coincided with the ending period of the BP3; then a direct appointment occurred with regard to who will represent parents, fortunately I was involved in the last two periods of the BP3. Some of the board members came from BP3, some as community figures, and also a teacher representative (I-11).

Secondly, people nominated as school committee members were regarded as community figures. One school committee member was convinced that:

The person who can become a member of board of school committee was not restricted to parents of students. We can elect for instance a governor [of the province] as a board member or a kapolda [chief of the police in the province]. It is dependent on the school meeting decision (I-5).

This indicates that unlike the BP3, which is restricted to parents' representatives, the school committee has flexibility to recruit from any part of society. Of the five state secondary schools that participated in this study, it was revealed that the chairman and secretary positions in each school committee were filled by well known figures and authorities. One school had a rector of the only state university in the province, and a school supervisor as chairman and secretary respectively. Other schools had success in recruiting the head commissioner of the state bank, high echelon officials from provincial or district government, 
prominent businessmen and public figures. This was planned by the principals.

One principal acknowledged what he had done in the school annual meeting:

In terms of the formation of the school committee, I have to put in the right people as board members. I should know him/her personally, s/he has interests in education and be useful for the school. If the committee makes too many troubles, I can dismiss it, that's my perception....For the chairman position, of course, it should be someone who I know more. And I told the parents in the school meeting when they asked about the committee positions, ‘don't worry I know good people who are knowledgeable about education and they are willing to be involved'. So, there was no tension in the meeting, it went smoothly, and I can put the right people on the committee's board (I-12).

The motive for recruiting prominent figures of the community was based on the assumption that their influence can be used to help the school. One teacher gave an example of this,

When we started to recruit people for school committee's board, the principal and teachers maintained that s/he should be an important person who has power in executive or legislative. This is because s/he can help the school whenever the school makes any kind of proposal, so s/he can facilitate our plan and make recommendations. Then s/he can directly say to the executive to approve our proposal (I-17).

One difficulty, however, was time restriction. High profile people are also busy people $^{3}$ and one teacher described:

The real obstacle with the board of the school committee is to find time for meeting. Sometimes we have to come to their workplace, because there is no alternative. For instance, the treasurer of our school committee is working at the mayor's office, and then we have to meet there. This is because all of them are busy and important people (I-15).

Since the principal controlled the meeting, he was the significant individual who arranged for the people to be available for appointment. Recruiting of high

\footnotetext{
${ }^{3}$ During data collection, the researcher also found it difficult to find time for interviews with school committee members. Some of them were really busy and it was very difficult to spare time for interview, some of them having to change the commitment several times.
} 
profile people had its advantages for the principals. It improved the school's bargaining position in the society in general, and on the other hand it could be used in the principal's best interest for any kind of problem. For example, parents who complained about the amount of school tuition fee would feel hesitant to confront community figures. The committee was also comprised of representatives of the administration, the teaching staff, students and alumni. Several responses from the participants revealed that principal's vested interest was evident in nominating people for the school committee. One teacher (I-18) claimed that the principal himself purposely put him on the committee as the teacher representative; similar practices also happened in schools of I-15 and I19 (teachers) and I-11 (school committee member). In one school, even the alumni representative (according to a teacher I-17) was a permanent teacher in the school. These actions drew criticisms - one teacher was convinced that the school committee had become the principal's puppet. He commented:

Many facts suggested that bureaucratic [district education officials and principals] interference was too much in the formation of school committee. This does not support the democratisation process that was intended by regulation. So, it shows that democratisation in schools is not something wanted by the bureaucrats (I-6).

However, as suggested previously (see Chapter 5), the regulation itself gave many privileges in terms of process to committee members and yet still fulfilled the regulation's mandate.

Thirdly, in terms of school committee composition, in most schools as shown in Appendix 7.2 (school committee member's profile) the majority of members had served on the BP3 board or as common members. Several participants suggested that they only practiced changing the name of BP3 to 
school committee to comply with the regulation. One teacher stated this experience as it happened in his school:

Researcher (R): How was the formation process of school committee in your school?

Participant (P): It is just continuing of the BP3, old board members just change the name to school committee.

$\mathrm{R}$ : all the same personnel?

$\mathrm{P}$ : Apparently.... from the BP3 members like $\mathrm{Mr} \mathrm{X}$ [the chairman of school committee], he is a community figure in Mataram, though he didn't have a child in the school. The treasurer, Mrs Y, who still has a child who is a student in the school; the secretary is a figure of one of the non-governmental organisation. This is because the old board members fulfilled the requirements needed [that stated by the regulation], then we just changed the name from BP3 to school committee (I-21).

Another teacher from a different state school noted:

As far as I know, the BP3 held a meeting which also invited several people who were nominated to be included in the school committee. Because, it was still periods of service of the BP3, then we just changed the name to school committee. Automatically the chairman and other board members were similar to the BP3, and some new people as additional ordinary members to become the required community representatives (I22).

These explanations revealed what could happen in practice to the creation of the committee in the school. Previous practice by the BP3 had not seemed to change (see sub-section 7.4.2). However, there was one school that used this opportunity to completely transform the BP3 and recruit all new people for the school committee. One teacher explains this:

Our school committee members are all new people. This was because the last chairman [of the BP3] was interfering too much, mainly in the refurbishment project that occurred in the school. He was not a developer, but he took the project. Then, we considered this with other teachers, and concluded he was not the right person to help the school, we have to get rid of him. Beside in the 3 years in his service as the BP3 chairman, the previous principal clashed with him....the school tuition fee was not increasing at all in those periods (I-15). 
Participants' responses to question Q9c regarding the committee’s roles, indicated that all groups of the stakeholders were generally aware of the changing roles. This is not surprising since the main and only role and function of the BP3 was to collect money from parents, whereas the committee as stipulated had four roles and these were promoted extensively. The interview responses indicated that the educators and committee members responded similarly about the broadening role of the committee and felt that it was a beneficial development. For instance, a principal commented:

There are bits of difference, but mainly the same. School committee's authority is more far ranging [than the BP3], such as the committee can give many inputs regarding design and planning of particular programs to the school (I-16).

However, not all of the committee's roles have been apparent. A comment from one school supervisor illustrates this as follows:

The role as advisor is rarely used by the committee; supporting role is limited only to supplying the funds that the school needed; as a controlling agency.... only practiced when there was the annual school meeting just to stipulate the amount of money that had to be paid by parents regularly; and mediator role was only used when they thought it was necessary to get involved (I-1).

Several teachers also confirmed that many suggestions regarding the school programme arose mainly from them, while the committee simply approved the ideas. Typical remarks from teachers in two different schools were:

It could be good if the committee would give inputs with anything that needed to be supported. But, right now everything is proposed by the school. The committee is actually always in agreement with the program that we propose (I-15).

I think the committee is always cooperative with us. Everything that we proposed is approved by them. In terms of fund raising for that program, school policies, is always accepted (I-21).

These explanations suggest that some committees tend to agree to most things that the school suggests. An expansion of roles assigned to the committee is still 
to occur. By contrast, according to one school committee member who served as a board member of the BP3, there was no difference between BP3 and the school committee:

I think when we were running the BP3; we already practiced what we now call the school committee's role. From my point of view, what we have done is just like that (I-14).

It seems that, although the BP3's role was not similar to the school committee, the latter is administered like the former. This indicates that previous practices and procedures are still used in the committee, because it is operated mostly by the same individuals.

The two last questions regarding school committees (Q9d and Q9e) asked about the committee's real influence in the school as perceived by school stakeholders. All principals, all school committee members and the majority of teachers responded that the school committee has the right to control educational implementation and their authorization is compulsory for school budgets. This view reflects the broadening of the committee's roles and functions, and all groups of respondents felt that this kind of power-sharing should happen.

However, data from the interviews revealed a different picture. Generally, respondents perceived that there was limited power sharing in terms of the control of the committee in relation to educational implementation. A school committee member explain this issue as follows:

We try to be independent, this means that the mandate from parents is something that we are all committed to. For instance, in terms of budget, we are very strict, the fund that came from the parents has to be accounted for accurately, how it is spent and it should be based on a budget plan that we agreed on....We asked those kind of questions of the principal. But we are also cautiously not to interfere in the education process, we are still in the corridor which means not involved in school technical matters (I-14). 
Another committee member (I-11) from another school responded similarly:

Researcher (R): What are the committee's involvements in educational implementation based on given authority?

Participants (P): We always cooperate; consultative process is how we deal with the school. Frankly, in our school, we as the school committee do not interfere much, there were many things we were not involved in .

$\mathrm{R}$ : What if there is a lack of teachers?

P: We are not involved at all.

$\mathrm{R}$ : So what really happened then?

P: We just pleased the principal; we only supported the school in terms of financial, fund raising and the like.

These two interview participants' descriptions indicate that, although all groups of respondents felt that the committee had rights in terms of control of school business, in reality this only involved marginal supervision of the budget. This new is in accordance with those already discussed in previous sections (section 7.5).

Regarding the committee's endorsement of the school budget, the practice in all state schools was the same. A school principal (I-20) explained the main reason for the continuation of the practice:

Researcher (R): Did you ask the district government for all the actual money that the school needed yearly so you don't have to collect money from parents?

Participants (P): Off course we did. We made an official request to the parliament and the executive based on our annual expenditure outside teachers salary.

$\mathrm{R}$ : Was it granted by them?

P: Oh, you don't have to ask that. If we asked for ten, actually they would give us about half. I think it is impossible. We asked the government about the funds we needed, it is always refused, what can we say? No other choice but to ask parents for help. Even, in this early academic year the district government promised to give us 750 thousand rupiahs [equal US\$ 75] as a subsidy for the new student admission process in every school. The fund is needed because we conducted student's entrance test mandated by the government which is for transportation, consumption and to buy office stationary. However, they only gave us the money after tremendous effort and so we informed 
the local newspaper about that. That's the reality, and it is difficult to deal with.

In practice, the limited amount of non-salary budget for a state secondary school located in the city is only enough to administer the school for four months. As a result, money from parents becomes a strategic source of income enabling the school to function for the whole academic year. Two teachers (I-15 and I-21) who were involved in budget planning revealed that total parental money compared to the full amount of money from the government (salary and nonsalary fund annually) was at a ratio of $1: 2.5$. This significant contribution then led to increasing the committee's bargaining position at least in terms of authorization of the school budget. Because of the considerable amount of money involved, a dedicated employee in the school is made responsible for it. His/her job is usually to collect school fees from the students regularly and to deposit these in the school committee's bank account (I-13, I-15, and I-21).

Like principals, teachers and administration staff who have an extra income from the school budget (in addition to their salary as civil servants, see sub-section 7.4.2), the committee members also have this additional funding source. Although the proportion has not reached more than 5\% of the school budget, it was bigger than the amount a teacher would receive. Comments from principals and teachers from two different schools confirmed this:

R: Does the committee member receive an honorarium like BP3 in the past?

$\mathrm{P}$ : It is the same, that is our policy, and it is an agreement reached between the committee and the school. Well, we also understood, actually they own the money. It can be given to them as a meeting stipend, monthly honorarium, or in terms of goods, basically it depends on the agreement. Usually at the end of the school financial periods, there is still money left in the balance, so we buy thing like clothing (etc) for them (I-16). 
What really happened in our school... the committee members themselves who already know amount of fund from parents and its allocation, also asked about regular honorarium? They think, they fill the positions, doing the job and have responsibility, so automatically they should take a share from it (I-17).

\subsection{Effects of SBM policy on the school}

This section explains participants' views and practices about SBM policy and its effects on the school. Questionnaire responses from school stakeholders are shown in three tables, and the result is discussed together with data from interviews. This relates to views about the policy itself, it benefits and constraints, and the changing roles experienced.

Table 7.4 shows groups of participants' responses about the SBM policy. Two groups of respondents, principals and school committee members, felt that the policy was appropriate to implement in their schools. The principals' responses was easy to understand. Because of their structural positions in the educational bureaucracy it was unlikely they would refute the policy. Further, the policy arose from their superiors so the principals had to implement it. For the committee members, it was apparent this policy involved them as part of a legitimized school community. The members saw that the previous system somehow excluded them from school, but involved them as agents for school funding. In this new policy, their role was expanded (at least in theory) and there was a promise that the school would be more responsible to it stakeholders in the community. The majority of teachers, 43 out of 57, also agreed that the SBM policy was appropriate to implement. Only a small proportion of teachers felt unsure and did not agree. The teachers' support of the policy was probably based on their feelings that the committee would help them if they also had a representative on the committee to take care of them. 
Table 7.4 Participants’ view about SBM policy

\begin{tabular}{|lccc|}
\hline Q10 & \multicolumn{3}{l|}{ Is SBM a good thing for your school? } \\
& Yes & Not Sure & No \\
& 5 & - & - \\
Principal & 43 & 13 & 1 \\
Teachers & 21 & - & - \\
School Committee & 21 & \\
\hline
\end{tabular}

In terms of benefits and constraints of the SBM policy, all groups of respondents clearly show (Appendix 7.10) that they felt the policy was more positive. Generally, a majority in each group felt that the policy brought many advantages to the school. For the principals, SBM would enhance their school operations. The teachers' viewed participation in decision making and control of school resources as key priorities. For groups of school committee members, involvement in it was their major concern. These optimistic responses from all groups mirrored the data from interviews. Participants listed what they thought the benefits of the policy were. Some of these were:

- Empowering community and parents about education issues (I-17)

- Schools developing themselves based on their distinctive features to achieve excellence (I-7, I-20, I-21)

- Power leverage to principals and education bureaucrats (I-17)

- Democratisation in education (I-6)

- Intervention from central and provincial office is limited (I-21)

All groups of respondents felt that there were not many constraints faced in the implementation of the SBM policy. However all groups put lack of resources and funds as their top constraints. This seems to be a reality that has to be faced by every state secondary school in Mataram, and arises mainly because of students numbers as discussed in the previous section. Interestingly, only 3 out of five principals answered this question. This means that for the principals 
the SBM policy did involve any serious concerns except in terms of the perceived lack of resources and funds. They also wanted to give the impression that nothing was wrong with the policy regardless of the many documented limitations. It could be that it was because the new policy operated in a similar way to the previous system which made the principals believe that not so many constraints existed.

Generally, the groups of teachers' felt there were not too many constraints with the introduction of the SBM policy. Only 17 out of 57 (30\%) of the teachers saw a link between the policy and their main job in school, which indicates that most of them saw SBM policy as still not connected to teachers' work. Because only a few teachers in each school were involved in school committee activities, only eight wanted training in SBM. Only four of them had experienced or known about the committee’s operations.

Similar responses also emerged from the group of school committee members. Only 10 out of 21 who participated in the study felt they needed training for their involvement in the committee. The reason for this was because most of the committee consisted of board members of the BP3, and they still operated in a similar manner. Most members had also experienced that the committee's meeting they had attended (which is at least one a year) had proceeded without any tensions. However three participants felt that the meeting involved an element of time wasting.

One teacher (I-3) believed that SBM policy was good but its implementation was problematic and he identified the source of the problem as the education bureaucrats. Another teacher (I-21) also considered the policy good, but was concerned that the committee interfered in school business such as 
dictating students admissions. An educational bureaucrat responded that the real limitation of the policy was the principal:

I think the major constraint is the principals. They are not as capable as expected such as implementing SBM policy creatively, full of fresh ideas, working effectively in short excellent. If the principals had those characteristics everything will be done (I-7).

These perspectives above, like others, generally portrayed the policy as advantageous, but identified a lack of knowledge about SBM issues in general (see chapter 5 for comparison).

Three groups of participants' responded that their role changed because of the SBM policy, though not significantly (Table 7.5). Two principals felt that their roles changed to a large extent but the rest of them responded that change had seem more limited. The majority of teachers and school committee members also noted similar changes. Overall, it was perceived that there was a smooth changeover when the policy was implemented.

Table 7.5 Participants' view about role changed because of SBM

\begin{tabular}{|c|c|c|c|c|}
\hline \multirow[t]{5}{*}{ Q13 } & \multicolumn{4}{|c|}{$\begin{array}{l}\text { To what extent has your role changed as a result of the move to } \\
\text { SBM? }\end{array}$} \\
\hline & & a large extent & some extent & Not at all \\
\hline & Principal & 2 & 3 & - \\
\hline & Teachers & 11 & 42 & 4 \\
\hline & School Committee & 3 & 18 & - \\
\hline
\end{tabular}

By contrast, data from the interviews revealed that for several participants the introduction of SBM policy had not resulted in changes as expected. Two teachers from different schools commented that even though the SBM policy had been implemented in their schools, nothing much had really changed at the school level: 
Nothing changes felt, just like the previous system (I-21).

Generally, everything is the same (I-22).

Several teachers in the site studies made similar comments. This phenomenon is not surprising, because the SBM policy only emphasised a new structural institution (the school committee) but its practices at the school level remained similar to the BP3.

\subsection{Attitude toward SBM policy and practices}

In this last section, groups of respondents were asked about participants’ attitudes to SBM policy and its practices in their school (Appendix 7.11). Generally all groups of respondents had a positive attitude, except for Q14c and Q14q where some of them had different views.

Principals' attitudes to SBM were mostly positive with regard to all aspects. All principals' agreed that the SBM policy resulted in more effective school management, improved decision-making and increased student achievement. Most of them also thought that SBM would increase community involvement, improve the relationship, and improve teachers' jobs, giving them more freedom. By contrast, one principal thought that the community involvement in SBM would not work, and one principal also thought there was no relationship between SBM and the extent of teachers' freedom.

Teachers' attitudes to SBM were also positive. They saw it as improving the decision making process (95\%), making schools more effective (86\%), improving relations with the community (84\%), promoting effective teaching (75\%), facilitating freedom in the teachers' job (67\%), improving student achievement (65\%) and increasing community involvement. Interestingly, the teachers' responses were high in terms of school management (the top two 
attitudes) compared to schools' core business which was teaching and learning (65\%-75\%). It seems that teachers do not always welcome community involvement, in terms of decision-making processes in school.

School committee members' attitudes to the SBM policy were quite similar to the educators. They thought it could make schools operate more effectively (100\%), improve relationships between the school and community (100\%), improve decision making (95\%), promote effective teaching (86\%), improve student achievement (81\%), increase community involvement (76\%) and promote freedom in teachers' jobs (52\%). Interestingly, they viewed their involvement in school very positively. By contrast, a minority of them regarded SBM policy as not relating to teaching practice.

\subsection{Conclusion}

This chapter has unfolded the perspectives and practices about the SBM policy as perceived by school and district level stakeholders. Undoubtedly, the principals' powers highly influenced the kinds of implementation of the SBM policy in the state secondary schools. The principals' control started from dissemination of SBM information and formation of the school committee, to the setting of the agenda for the school annual meeting. This was a legitimated form of hegemony. At the same time, many responses indicated that most principals were not prepared and motivated to implement the policy as expected, but managed to the extent somewhat stipulated in the regulations. In addition, teachers and school committee members could only contribute to the implementation as long as there was time and opportunity for their involvement, given by the principals. 
The findings in this chapter provide suggestions for reform of the existing SBM policy in Indonesia. The centralisation of power that had been practiced in the previous era at every level of the education system is still prevalent. The policy-makers who wanted to transform the system, constructed a policy that actually became an instrument to strengthen the establishment. Whereas policy construction with clearly stated rights and authority for each stakeholder could lead to different and more positive outcomes. Also the whole process has to be transparent and accessible to every involved party, which would lead to a practice of more genuine power sharing.

Many issues identified in this chapter are interrelated with those already discussed in the analysis chapters, and these will be returned to and examined in the final chapter. The next chapter will corroborate the findings, and set the agenda for the future of school based management policy in Indonesia. 


\section{Chapter 8}

\section{CONCLUSIONS}

\subsection{Introduction}

This study investigated SBM in Indonesia with a particular focus on the state secondary school level in Mataram. The study examined the current Indonesian education context; its educational decentralisation experience and compared this to the SBM issues internationally. The study analysed specific policies as stipulated nationally, and collected and analysed field data from educational stakeholders at district and secondary school levels (Chapter 5-7). The study used a triangulation approach with different sources of data, thereby enhancing the credibility of its findings. The following three broad findings are noted.

- The SBM policy: the study problematized how the policy was portrayed nationally, stipulated and dispersed at district and school levels. As well, the study showed how these portrayals were manifested in stakeholders' perspectives and practices.

- The devolved authority: the study examined the devolved regulations as stipulated nationally and implemented locally. It also exposed the perspective and practices of stakeholders regarding devolved authority.

- Community involvement: the study discussed how regulations positioned the community; how they were portrayed at district and school levels; and how these regulations were manifested in stakeholders' opinions and practices. 
In this concluding chapter, the main findings reflecting the issues listed above are discussed in relation to the research questions outlined in Chapter 1 . This final analysis has also taken into account relevant literature on SBM. Implications for SBM in Indonesia are discussed together with a possible agenda for reforming SBM in the country.

\subsection{Overview of research findings}

In the following subsections, brief overviews are given of SBM.

\subsubsection{The SBM Policy}

\section{At the national level}

The study found that the SBM policy at national level, namely the Kepmendiknas 044/U/2002, lacked clarity. The regulation did not establish obligatory institutions as mandated. Nor did it offer clear statements about the transfer of powers for community involvement at district and school levels. There was also vagueness in the contents of the decree relating to governance and management arrangements. Inconsistent with a previous study which supported the decree, the Kepmendiknas was not based on fieldwork research and public consultation. Instead, it had a political purpose, to demonstrate that the government cared. The regulation implied a uniform model of SBM regardless of school level, size, location, type of community, or whether schools were public or private. Also it did not differentiate between public-secular and Islamic school systems. Moreover it was not clear what type of SBM was intended to be established. This study revealed that the policy was corrupted by ideas about SBM originating from Western models, without sufficiently attempting to acknowledge the Indonesian context. It appeared that the central 
office could not position itself appropriately in view of the demands of the changing landscape of public sectors including education. It was obvious that central office personnel were not sufficiently experienced or adequately prepared for the reforms. Furthermore, it was obvious that the implementation of the SBM policy as planned was unrealistic due to the politically driven nature of the autonomy law. It had been recommended by a donor agency, emphasising structural changes, namely, the creation of education councils and school committees. To recap, the characteristics of the official SBM policy in Indonesia are: centrally initiated and formulated; centrally stipulated without adequate research and public discussion; implemented with uncertain and unclear regulations; and emphasising structural changes.

\section{District level perspectives and practices}

In the case of Mataram, the SBM reform did not include subsequent policy development to regulate district level implementation. Consequently, no clear legal guidelines were in place. It was obvious, therefore that attention by both the legislative and executive arms of government to education at the district level was minimal. The only indication of their concerns was through the district budget, with $20 \%$ of it allocated to the education sector. These funds were used, however, for infrastructural projects such as the building of new schools and refurbishment of school buildings. The study found that the education district office had released some policies, supposedly relating to SBM, but these merely continued previous practices and, to some extent, the policies failed to strengthen school autonomy. Limited staff capability and the absent of capacity building programmes to support SBM, led to the district education office down-playing educational activities. Educational reforms were therefore based on the minimum 
requirements of the bureaucracy. Consequently, schools ended up directly intervening. This is, in fact, the legacy of the previous Indonesia regime. It seemed that an easy way for the government to deal with the autonomy era was to retain an old paradigm and approach. The one obvious change originating from the SBM policy at district level, was the major decree concerning the establishment of education councils.

\section{School stakeholder perspectives and practices}

The study found that dispersing information about the new policy to school stakeholders was not systematic or programmed. It was conducted in a manner that did not provide much information. Only a small proportion of stakeholders participating in SBM training had knowledge about the policy. This means that teachers and school committee members relied heavily on information about SBM from the principal. In terms of establishing school committees, the study noted that all schools which participated in this study had school committees. The staff of these schools perceived the policy as being a good one. However, as the study noted the lack of clear guidelines to the district level meant that district level practices of SBM continued to reflect previous practices. In this way, SBM was superficially implemented at the school level mostly by the principals.

\subsubsection{Devolved authority}

\section{At the national level}

The study revealed that neither in the decree's content or in its appendices was there a mention of devolved authority. The reference to devolving authority only appeared in the documentation giving further 
explanations to the SBM policy. However, authority which was suggested to be exercised by the schools, was in fact already practiced, and these were only marginal discretions. A similar case also existed for education council institutions. The non-existence of explicit devolved authority in the policy raises serious questions. For instance, to what extent is a school committee acting legally when it is collecting money from parents? How legal is such a practice without proper legislative authority? The absence of properly devolved authority in laws demonstrates a decree formulation which was ill-prepared and not adequately thought through.

\section{District level perspectives and practices}

Under the autonomy law, the transfer of powers regarding public sectors to district level was taken for granted. As noted, the legal transfer of laws was not shared with educational governance institutions at the district level (education council). In turn, devolution did not take place further down to the school level. The district was also limited and late in terms of providing capacity building to school stakeholders about SBM. The study noted that the legislative and executive further intervened, imposing a 'geographical fence' policy regarding students who entered public schools. In addition, the limited capacity of the district education office had meant that it could not operate in newer ways to strengthen school autonomy. Instead, practices remained as they had been previously.

\section{School stakeholder perspectives and practices}

The study found that school stakeholders generally agreed that authority could be devolved to the school level. The basis for their view appeared to have 
been their experiences and what had been practiced for some years. Regarding three essential matters of authority (budget, staff and curriculum), which are usually devolved in the SBM policies elsewhere, Indonesian secondary schools in reality are neither supported nor given much flexibility to implement these. Participants generally welcomed the concept of the transfer of powers to schools, though they also realised that doing so needed time so that ways of thinking and attitudes could also change. The study found that with the introduction of SBM, school practices had not changed. The study also showed that principals were reluctant to share powers and to be accountable to other stakeholders. It was noted that in some matters, principals used their authority to be secretive about the concurrent budget (routine budget) thereby providing minimal information to stakeholders. However, the schools cannot rely on concurrent budgets from the district government which only gives, on average, one tenth of actual school operational costs (non-salary budget). Such a situation has led the school to collect funds from parents through the school committee on a regular basis. The practice is, however, flawed, with limited transparent and accountability systems. Regarding staff management, the schools studied do not have any flexibility, as the responsibility for all school personnel is held by the district government. It is as this level that educators are recruited and decisions on professional development are made. In addition, the study found a disturbing development whereby appointments of educators of particular ethnicities were made to strategic positions. The study found that authority for the curriculum was still held by the central office. District and school levels acted only as implementing agencies. 


\subsubsection{Community involvement}

A key intention of the SBM policy was to strengthen community involvement in education. But the study revealed only superficial participation at the district and school levels. It also demonstrated that participation was not adequately covered in the contents of the decree.

\section{At the national level}

The study found that one weakness of the SBM policy was that it did not differentiate between community involvement at the district level from that at the school level. The similarity of roles and functions for the education council and school committee was designed to make these two institutions operate without actual authority. Both the council and committee operated in advisory capacities. Both respond to and are dependent on the bureaucracy without any resources or legislative mandates. Regarding the education council, there was no obvious indication about its clients, which was problematic at the district level.

One of the functions of the school committee appears to be to generate funds for the school budget without proper acknowledgement of the sources of the funds. This practice is supported in practice as a way of hiding the inability of central government to support education adequately. There is vagueness in terms of which particular members of the society can join the committees. It seemed that the party with power is able to dominate the committees.

\section{District level perspectives and practices}

At the district level, the education council is a forum for community involvement. The council, however, may be considered as a sub-ordinate of the executive. Although board members come from different parts of the 
community, they are hand-picked and shoulder-tapped based on the executive's preferences. Limited support from the bureaucracy and the incompetence of untrained members of the council has made the council focus on certain tasks while neglecting others. The council appears to be always bargaining its position and roles with the district education office.

\section{School stakeholder perspectives and practices}

School stakeholders saw community involvement as an additional source of resources for the school in terms of funding and free labour. Further, the community was seen as a supporting agency of the school committee. In this sense, the school committee is mainly used by the schools to legitimize all kinds of policies, but particularly when stipulating school budget and fees. Generally, school committees represent elite sections of the community, with members who are handpicked by the principal. This appointment process is a provision of the regulation. Through this practice, the principal preserves his own power without sharing it with others. The study noted that the committee has seen itself mainly as a source of funding for the school. Its involvement is exclusively in relation to fundraising which clearly shows a continuing practice of the previous institution (the BP3).

\subsection{Discussion and implications}

\subsubsection{The SBM policy at national or district level}

The MoNE policy concerning SBM was influenced by the study conducted by national academics, field work in some regions, and involving many stakeholders and donor institutions (Kompas, 2000a; Jalal \& Musthafa, 2001). This situation has some parallels but not exact to what happened in New 
Zealand (Barrington, 1997) and Australia (Caldwell, 2002). The SBM policy was also influenced, to some extent, by the public in its call for improving the effectiveness of Indonesian education (Kompas, 2000c; 2000e; 2000f). However, the Indonesian case is different from many others internationally in that those who wrote the decree, while influenced by political considerations (Wirt et al., 1985), were officers of the MoNE. These bureaucrats had minimally been involved in the design of the previous study, and were unclear about how to fit SBM within the new autonomy regime. As a result, this SBM policy, from its design to implementation stage, was deemed to be ineffective, as the preconditions for making it work were not in place (World Bank, 2004).

Further to the findings in the previous sections, a number of other considerations are pertinent to the failure of the Kepmendiknas. Firstly, a new law had subsequently been adopted to regulate and reform the school system according to SBM policy. This new law (Law 20/2003) had adopted a new paradigm, clearing the way for a new governing system based on decentralisation. Sections of the new law have explicitly provided for school based management, community involvement in the form of education councils and school committees, conditions which were absent in previous legislation. Unlike the Kepmendiknas, which was based on previous bureaucratic-centralism education system law (Law 2/1989), the new regulation about SBM which was released by the central office could be the basis for a government regulation which had a much stronger legal basis than the previous ministerial decree. As a government regulation stipulated by central office, the new regulation set the standards regarding SBM policy issues, allowing for authority which had already been devolved to the district level, to be used. In addition, the central office's 
role could be that of a supporting agent to the district level, helping in the design of SBM policies for particular districts through the legislation process.

Secondly, it is suggested that the inadequacies of the existing MoNE policy document's content can be improved in the following manner: a) use clear statements to avoid ambiguity, tension and conflict in the actioning of the policy; b) acknowledge the diversity of Indonesian schools and society and do not assume a one-size-fits-all approach; c) differentiate between governance and management and ensure that devolved authority to certain levels respects the division; d) recognize community involvement as genuine participation in terms of transparent and accountable mechanisms. It is possible that the above suggestions can be incorporated in the formulation of either national regulations or district legislations. This point is further explored below.

The decree's formulation should provide clear guide-lines in the use of such phrases as 'mandatory' or 'compulsory', rather than 'can be used'. In this way, clarity of meaning and expectations are established up-front for community involvement both at district and school levels. It is possible, when regulations are not clearly written, for people to exploit the laws, based on their own interests. In particular, the parties or groups that are in power can easily exploit such laws. The need for clear definitions and avoidance of multiple interpretations in a decree has been suggested. Sadly, some have experienced conflict arising from multiple interpretations (see, for example, Wyle, 1995; Fullan and Watson, 2000). Confusion and tension are common, particularly at the school level regarding responsibility and authority, where imprecise words are used in the regulation (Daun, 2000). In the case of the Kepmendiknas, the wordings are not based on comprehensive research of the Indonesian school system. Carefully 
chosen words to regulate SBM policy must also be backed-up by research on the current school system. The other need is to involve all interest groups at the different stages. This study showed that stipulating a decree with limited public consultation and using a coercive model by which the central office controlled everything, resulted in vagueness and a confused policy. There needs to be an agreement when establishing a consultation process to include from the beginning. Such processes will reduce misunderstanding and gain greater consensus from all parties (Fiske, 1996; Gershberg, 1999).

The diversity of Indonesian society is considerable. Consequently, one of the aims of the autonomy law is to acknowledge this diversity. In addition, diversity is also seen at the district level. To impose one model of SBM policy nationally at various school levels, for different sizes, locations and types of communities ignores of the diverse Indonesian context. By comparison, several states in the United States and Australia, with their diverse societies, have attempted several models of SBM, based on their school and community cultures and histories (Murphy and Beck, 1995; Caldwell, 2002). This study has shown that the failure to acknowledge complexities and diverse local contexts by policy makers has contributed to the policy failing to meet expectations from the beginning. Ideally, the central office can provide variations of SBM models from which particular district governments might choose. An administrative model of SBM where the principal is dominant, for instance, might be selected where principal selection and recruitment are merit-based. A community control model might be implemented where a community is more knowledgeable about education. Moreover, since the debacle of the New Order regime, Indonesian society is flourished with people movements, and stipulating uniformity in terms 
of an SBM model and placing of community involvement can be seen negatively as a return to the previous era. Another related issue is that the policy which emphasised structural change, namely establishing education councils and school committees, led to superficial implementation instead of improving the capacitybuilding and reculturing that was supposed and necessary to support the policy (Fullan, 2001).

As mentioned, another failure of the Kepmendiknas related to its unclear definitions and lack of differentiations between management and governance both for district and school levels. At the district level, governance resides with the district parliament, which means that the education council at best has an advisory role rather than a management one as stipulated in the decree (World Bank, 2004). An ideal single agent in governance and management is much more sensible compared with an education council without clear or no authority, capacity and support. At the school level, the situation is different where a school committee can effectively learning the principle to manage. Therefore the starting point for policy makers is to decide which authority to devolve and to whom at the school level. Considerable contextual knowledge about the school is necessary so that the kind of SBM model selected is appropriate to the school system in a particular district. The details must be clearly defined in the decree. The various roles must be clearly stated; what is to be shared, what hands-on roles (the committee members actively involved in actually implementing policies) and hands-off (where the committee's role is only on a policy one) roles are agreed upon. Doing so will result in a much more healthy relationship, where certain issues such as curriculum, personnel, property, finance and discipline are handled by the people who hold particular expertise and authority. 
To obtain genuine community participation at district and school levels, something needs to be done with the mechanisms for recruiting stakeholders. Previous practice (see Chapter 6 \& 7) clearly showed that multi interpretations of a decree's contents and appendices had led to superficial implementation. Analysis of the decree (Chapter 5) indicated that there is a hidden agenda from the central office to preserve bureaucratic power both in the education council and the school committee. In addition, transparency and public involvement should be formulated in the decree so as to lead towards community awareness, and societal participation in education (Bray, 2000). In order to make both institutions become part of an effective bureaucracy, membership of the committee should be more focussed. For instance, an education council with an advisory role does not need members from the bureaucracy or the legislature. Meanwhile there is also a need to clarify meaning about community figures. Who are these individuals? At the school level, it may be more sensible that representatives of teachers be elected by the teachers, and parents' representative be chosen by parents. Again, the mechanism to recruit should be open to the stakeholders and the general public with proportional accountability. In terms of equal opportunity based on gender and minority groups, the decree must acknowledge and allow for equal representation in the composition of communities.

\subsubsection{The district level}

The analysis of district government support for the SBM policy in Chapter 6 showed that there are some issues to be resolved. First, there needs to be some basic understandings about the education system for the policy makers, both in the legislature and the executive. Understanding can be enhanced through 
seminar participation, particularly with specific exposures to make policy makers more aware of educational issues. It is obvious that the low level of understanding by policy makers has resulted in poor leadership and vision for SBM, particularly at the district level. Enhancing knowledge and skills also should be encouraged in technical institutions that recruit people for positions in district education offices. Limited personnel capability in the district level also can lead to a minimal standard of bureaucracy that could be manipulative. Regular use of local media such as the radio and local newspapers to communicate; and inviting the public to scrutinise plans and activities, are healthy ways of engaging the public about educational issues and democratisation.

Second, involving the public from the beginning and keeping communication lines open about policy in education and not just about SBM, both by the legislature or the executive at district level, are good ways of sharing power in education. Exposing district regulation plans concerning education or SBM to stakeholders through consultation or advice are recommended. As such, pre-requisites for policy implementation will be listed by every stakeholder and help avoid one-sided attention to structural changes without proper reculturing programmes (Fulan and Watson, 2000). Further, as found by Taruna (2001), disciplining bureaucracy at all levels (district, sub-district and schools) to act equally as other participants, in the Indonesian context will lead to greater trust, and openness and encourage genuine public participation.

Third, preserving the practice of collecting money from parents by schools indicates that financial support from the district government is not adequate or dependable. Whereas in fact, funds allocation for the education 
sector in the district budget is substantial (Chapter 6), showing clearly that school operational costs are not prioritized by the legislature and executive. Establishing a form of formula funding for non-salary budgets has to be stipulated ideally at every school level. Besides policy on equality, it is also important to ensure equity in terms of financial support through formula funding which is worth more than a designated 'geographical fence' policy. Further, if the practice still persists because of some reasons, then it is best this kind of fund mobilisation from members of society (i.e. parents) be legalised through district regulation. This is because in fact, public secondary schools with this kind of practice are playing roles as agents of tax collection without proper legal backing. The regulation can then stipulate the maximum amount that can be collected from parents, methods of collection, activities that can be financed with that money, and proper accountability report through independent auditors.

Fourth, as suggested by Fullan and Watson (2000, p. 460) "new policies and structures may be necessary, but are not a sufficient step for reform”. This means that continuing district support is needed and should be programmed accordingly. The study reveals that the failure of policy implementation can be easily predicted where three-way interactions are not happening between national, district and school personnel. In the Indonesian situation, did not happen even after SBM policy was implemented.

\subsubsection{The school level}

The study has revealed that limited information and support, accompanied by unclear regulations has resulted in schools continuing with previous practices and implementing SBM policy in superficial ways. Although the SBM policy is new for school stakeholders to manage, it is hand in hand with 
the spirit of decentralisation. The SBM policy, if administered effectively, can also be as instrument to make schools more open to the public, more transparent, accountable, and more inviting in terms of genuine participation by the community.

In order to make SBM policy really work, well prepared and highly motivated school principals are needed (Bangay, 2005, personal communication). The study found that most principals tended to practice an oldstyle paradigm of their role. They have continued to use an approach with an authoritative leadership style even after introducing a SBM policy. While their knowledge of SBM may have included notions of transparency, participative decision making and proper accountability in terms of running schools, these principals had found it hard to follow them in to act accordingly. One practice, explanation for this relates to unsatisfactorily principals' selection processes. They are often chosen by the bureaucracy, mostly in a secretive way which is not based on meritocracy. Changing the recruitment model for principals to involve other school stakeholders such as teachers and parents should make them more aware of public accountability. Further, disseminating policy can be accomplished more effective when the documents are easily accessible through a variety of sources, including openly discussing matters, rather than just waiting for official dissemination.

The school committee has now existed for a considerable time in each school since the introduction of the decree. It may be encouraged to reconsider its own roles and functions and, if permitted, determine what degree and kind of authority can be shared with schools. Self-owned capacity building programmes are likely to make the public more aware of the complexity of the SBM policy. 
The committee can also voluntarily request an independent agent, though no regulation exist for this, in order to audit the funds regularly collected from parents and to report on this to every stakeholder. When committee members are encouraged to participate in school planning, policy setting and activities, the result will be a more genuine feeling of participation on the part of the community.

\subsection{Future agenda}

Some future directions are proposed based on the findings of this study. The educational reform and SBM as part of the changing landscape in Indonesian decentralisation is undoubtedly complex. It is the view of the researcher that practical solutions more reasonably be implemented at the district level. This is because authority in education is legitimated by the autonomy law and takes place at the district level. At this location, power transfer is attainable and manageable particularly given the factors of population and area size.

Firstly, the Mataram district government where this study was conducted has the abilities to reform its education system as it wished. Having said that, it is necessary to carry out comprehensive research to analyse and assess the current education system if the best outcomes were to be achieved. This cannot be avoided since there is incomplete data about education and an absence of clear directions for education. The district government could invite experts and academics from the university, the central office, or consultants from donor agencies to conduct the research. The results of such a study would be informative and would provide a comprehensive picture for policy makers and practitioners at the school and district levels to enable them to take necessary action. 
One area of attention for such research would be to provide information regarding the most appropriate method for the recruitment and preparation of principals in order to get the best possible appointments to schools. The research should also provide information about merit-based and equal opportunity systems for teachers regardless of gender and ethnicity. Another focus should be to create student formula funding based on each level of education. Since the BP3 and recently the school committee funds from parents have often not been utilised effectively or appropriately. Relating to district budgets, the amount which is annually provide for the education sector makes sense only if the government can fund operational costs fully, based on actual school needs. On the one hand, this will be a real public service to society. On the other hand, such a practice encourages schools to be accountable, for their use of public funds.

Research could also offer insights about SBM policy in terms of what best suits the district at particular levels of schooling. In addition, as this study has identified, the new policy should explicitly state which authorities are most appropriately devolved to the local level in order to gain grassroots' responsibility. Any new policy emerging from public consultations and reached by consensus must also give clear guide-lines regarding external relationships where continuing reform is still open for discussion (Fullan and Watson, 2000). Having said this however, it is important that effective implementation of any new SBM policy must be adequately prepared for if schools and their communities are to be expected to support and own the policy. 


\subsubsection{Future Research}

There are several areas where further research into SBM would be useful. First, the new education legislation, Law 20/2003, and subsequent government regulations, require considerable general and particular scrutiny. Research on detailed regulations, their implications and applications for education councils and school committees need careful scrutiny. Unlike the Kepmendiknas 044/U/2002 which was based on the previous education law for centralised systems, the new education law relates to an education system in a decentralisation mode. Textual and content analyses of these new regulations should validate the present study, especially for comparison purposes. In addition, district level regulations concerning education specifically in relation to SBM in Mataram would be worth undertaking.

Second, fieldwork research located in Mataram has indicated further possible research directions. Mataram is a small municipality (kota) in the Eastern part of Indonesia. It would be worth knowing how SBM in Western Indonesia, especially in the more advanced regions of Java, is being experienced. Then a similar study in a comparable or different sized district (kota or kabupaten) in Western Indonesia (including Java) or other Eastern Indonesia regions would provide comparative information. Other districts that have established regulations regarding SBM would also offer insights for comparative purposes if similar studies were undertaken on them.

Third, this study examined state secondary schools. An examination of the SBM experience at other levels in state sector systems, namely elementary schools and junior high schools, would also provide useful findings for comparison. This is because the secondary level is regarded as more complex 
than the elementary level where students and parents will be more commonly members of the local community than is the case with secondary schools.

\subsubsection{Final Reflection}

Undertaking a research project of this nature was satisfying. I was able to spend time away from Indonesia, while allowed me to reflect on the implementation of SBM and its impact at the district and schools levels. The review was also challenging because stakeholders appeared unclear about key issues of SBM. Many continued to practice school management which did not reflect SBM. Many seemed to understand the decree and what was intended.

If I were to do the study again, I should have included, as participants, the designers of the decree from the central office. As well, a more longitudinal study would be valuable to show changes in stakeholders understanding and practices. Doing the study has, however, has prepared me to play a role in the agenda to reform education in Indonesia. 


\section{REFERENCES}

Abu-Duhou, I. (1999). School-based management. Paris: UNESCO:

International Institute for Educational Planning.

Ainley, J. and McKenzie, P. (2000). School Governance: Research on Educational and Management Issues. Paper presented at South Australian Institute for Educational Research. Flinders University. Adelaide. Australia.

Anderson, G. (1998). Fundamentals of Educational Research. Second edition. London: Routledge-Falmer.

Aspinal, E. and Fealy,G. (eds.) (2003). Local Power and Politics in Indonesia, decentralisation and democratisation. Singapore: Institute of Southeast Asian Studies.

Atkinson, P and Coffey, A. (2004). Analysing documentary realities. In Qualitative Research, theory, method and practice, edited by D. Silverman. London: Sage.

Bali Post. (2003). Jika digunakan standardisasi UAN, diprediksi 70 persen siswa tak lulus (It is predicted that if final examination used standard based criteria, 70 percent students not pass the exam). Bali Post, 8 April 2003. http://www.balipost.co.id/balipotcetak/2003/4/8/nt4.htm [online accessed 24-04-2003]

Ball, S. J. (1990). Markets, Morality and equality in Education. England: Tufnell Press.

Bangay, C. (2005). Private Education: relevant or redundant? Private Education, decentralisation and national provision in Indonesia. Compare 35 (2) pp. 167-179.

Barrington, J. (1997). Central and Local Control in Education. New Zealand Annual review of Education, no. 7. pp. 79-93.

Beeby, C. E. (1979). Assessment of Indonesian Education. Wellington: New Zealand Council for Educational Research and Oxford University Press.

Beck, L. G. and Murphy, J. (1998). Site-Based Management and School Success: Untangling the variables. School Effectiveness and School Improvement. 9 (4) pp. 358-385.

Bulock, A and Thomas, H. (1997). Schools at the centre? A study of decentralisation. London: RoutledgeFalmer.

Burki, S. J., Perry, E. G. and Dillinger, W. R. (1999). Beyond the center: decentralizing the state. Washington D.C.: The World Bank. 
Bray, M. (2000). Community Partnerships in Education: Dimensions, variations and implications. Paris: UNESCO.

Brown, D. J. (1990). Decentralization and School-Based Management. London: The Falmer Press.

Bryk, A.S, Sebring, P. B., Kerbow, D., Rollow, S. and Easton, J. Q. (1998). Charting Chicago School Reform. Boulder: Westview Press.

Caldwell, B. J. (1994). School Based Management. In Torsten, H and Postlehwaite, T. N. The International Encyclopedia of Education. $2^{\text {nd }}$ ed. New York: Pergamon. pp. 5302-5308.

Caldwell, B.J. (1998). Self-managing schools and Improved learning outcomes. Canberra: Department of Employment, Education, Training and Youth Affairs.

Caldwell, B. J. (2002). The Design and Implementation of Self-managing Schools in Australia. Paper presented at Conference on Autonomy in Education in the Indonesian context, at The Australian National University, Canberra, 29 September 2002.

Caldwell, B. J. and Spinks, J. M. (1988). The Self-managing school. London: Falmer.

Cheng, Y. C. (1996). School Effectiveness and School-based Management. London: Falmer.

Chubb, J. E. and Moe, T. E. (1990). Politics, Markets and America's School. Washington D.C.: Brooking Institution.

Clark, D., Hough, J., Pongtuluran, A., Sembiring, R., and Triaswati, N. (1998). Financing of Education in Indonesia. Manila and Hong Kong: Asian Development Bank and Comparative Education Research Centre-The University of Hong Kong.

Cohen, J. (2001). The Regulatory Structure Supporting Basic Education in Indonesia: Analysis Covering 1989 to Present. Working Paper Number VIII, Regional Education Development and Improvement Project (REDIP). Jakarta: the MoNE.

Creswell, J. W. (1994). Research Design, qualitative and quantitative approaches. Thousand Oaks: Sage Publications.

Creswell, J. W. (1998). Qualitative inquiry and Research design, choosing among five traditions. Thousand Oaks: Sage Publications.

Cumming, T. (1994). Alternatives in TESOL research: descriptive, interpretive and ideological orientation. TESOL Quaterly, 28(4), 673-703. 
Darmaningtyas. (1999a). Pendidikan pada dan setelah krisis (Education at and after crisis). Yogyakarta: Pustaka Pelajar

Darmaningtyas. (1999b). Pendidikan Militer(istik) (militaristic education). Kompas, 3 May 1999 http://www.kompas,com/kompas-cetak/9905/03/opini/pend45.htm [online accessed 18 June 2003].

Daun, H. (2002). Educational Restructuring in the context of globalization and national policy. New York: RoutledgeFalmer.

Davies, L., Harber, C. and Dzimadzi, C. (2003). Educational Decentralisation in Malawi: a study of process. Compare 33 (2), pp. 139-154.

Denzin, N. K and Lincoln, Y. S. (Eds). (1998). The Landscape of Qualitative Reseach. Thousand Oaks: Sage Publications.

Djajadiningrat, R.L. (no date). From Illiteracy to University, educational development in the Netherlands Indies, Bulletin 3 of the Netherlands and Netherlands Indies Council of the Institute of Pacific Relations.

Duflo, E. (2004). The medium run effects of educational expansion: evidence from a large school construction program in Indonesia. Journal of Development Economics 74:163-197.

Fajar, A.M. (2004). Sambutan Menteri Pendidikan Nasional pada upacara peringatan hari pendidikan nasional tanggal 2 Mei 2004 (Speech of the Minister of National Education in the celebration of national education day on 2 May 2004).

http://www.itb.ac.id/focus/focus_file/hardiknas\%2002-04-04.pdf [online accessed: 6 June 2004]

Feith, H. (1963). Dynamics of Guided Democracy. In Indonesia, edited by R. T. McVey. New Haven, Connecticut: Southeast Asia Studies, Yale University.

Filmer, D. and Lindauer. (2001). Does Indonesia have a 'low pay' civil service?. Bulletin of Indonesian Economic Studies 37 (2): 189-205.

Fiske, E. B. (1996). Desentralisasi Pengajaran, politik dan konsensus (Decentralization of Education, politics and consensus) (B. Bengoteku, Trans.). Jakarta: Grasindo.

Fontana, A. and Frey, J. H. (2000). The Interview, from structured questions to negotiated text. In Denzin, N. K and Lincoln, Y. S. (eds). Handbook of Qualitative Reseach. 2nd edition. Thousand Oaks: Sage Publications.

Fullan, M. (1991). The New Meaning of Educational Change. New York: Teachers College Press. 
Fullan, M. (2001). The New Meaning of Educational Change. $3^{\text {rd }}$ ed. New York: Teachers College Press.

Fullan, M and Watson, N. (2000). School-Based Management:

Reconceptualizing to Improve Learning Outcomes. School Effectiveness and School Improvement. 11 (4). pp. 453-473.

Gershberg, A.I. (1999). Education 'Decentralization’ Process in Mexico and Nicaragua: legislative versus ministry-led reform strategies. Comparative Education. 35 (1). pp. 63-80.

Government of the Republic of Indonesia. Peraturan Pemerintah nomor 25 tahun 2000 tentang Kewenangan Pemerintah dan Kewenangan Propinsi sebagai daerah otonom (Government Regulation number 25/2000 concerning Government Authority and the provincial authority as an autonomous regions). Jakarta.

Hawkins, J. N. (2000). Centralization, decentralization, recentralisation, Educational reform in China. Journal of Educational Administration. 38 (5), pp. 442-454.

Hodder, I. (2000). The Interpertation of Documents and Material Culture. In Denzin, N. K and Lincoln, Y. S. (eds). Handbook of Qualitative Reseach. 2nd edition. Thousand Oaks: Sage Publications.

Hofman, B. and Kaiser, K. (2002). The Making of the Big Bang and its aftermath. Paper read at "Can Decentralization Help Rebuild Indonesia”, at Georgia State University, Atlanta, Georgia. http://nweb.worlbank.org/eap/eap.nsf/attachments/041802hofmankaiser/\$file/hofmankaiseratlanta_3.pdf

Indriyanto, B. (2003a). Current Status of Educational Research: Indonesia Country Report. Paper presented at the 5th UNESCO-NIER Regional Meeting of Directors of Educational Research and Development Institutes, at Tokyo, Japan, 27-31 January 2003.

Indriyanto, B. (2003b). School-based management: Issues and Hopes toward Decentralization in Education in Indonesia. Paper presented at the 3rd International Forum on Education Reform. Bangkok, Thailand, 8-11 September 2003. http://www.worldedreform.com/intercon3/third/f_bumbang.pdf [online accessed 14 February 2006]

Jalal, F. and Musthafa, B. (Eds.). (2001). Education Reform in the Context of Regional Autonomy: The Case of Indonesia. Jakarta: Ministry of National Education, National Development Planning Agency and The World Bank. 
Jazadi, I. (2003). An investigation of current constraints and potential resources for developing learner-centred curriculum frameworks for English language at high schools in Lombok, Indonesia. Unpublished PhD thesis, Division of Education, Arts and Social Sciences, University of South Australia, Adelaide, Australia.

Kroeskamp, H. (1974). Early Schoolmasters in a Developing Country, a history of experiments in school education in 19th century Indonesia. Assen, The Netherlands: Van Gorcum \& Comp B.V.

Kompas, (1998). Lebih Jauh dengan Drs. JIGM Drost SJ (More depth with Drs JIGM Drost SJ). Kompas, 3 May 1998.

URL: http://kompas.com/9805/03/naper/lebi02.html

[online accessed 21 Feb 2000]

Kompas. (2000a). Mendiknas Berharap 20 persen Dana dari APBD (The Minister hopes that education budget for education in each district reach 20\%). Kompas 5 July 2000.

URL: www.kompas.com/kompas-cetak/0007/05/dikbud/mend09.htm [online accessed 5 July 2000]

Kompas, (2000b). Mendiknas Berharap 20 Persen Dana dari APBD (minister of nasional education hopes that $20 \%$ local government budget for education sector). Kompas 5 July 2000.

http//www.kompas.com/kompas-cetak/0007/05/dikbud/mend09.htm [online accessed 13 August 2003]

Kompas, (2000c). Manajemen Berbasis Sekolah segera diberlakukan (school based management will be implemented soon). Kompas 26 September 2000.

http//www.kompas.com/kompas-cetak/0009/26/dikbud/mana09.htm [online accessed 31 March 2003]

Kompas, (2000d). Manajemen Berbasis Sekolah sulit dilakukan dalam waktu dekat (school based difficult to implement soon). Kompas 27 September 2000

http//www.kompas.com/kompas-cetak/0009/27/dikbud/mbss09.htm [online accessed 31 March 2003]

Kompas, (2000e). Tahun 2001, dunia pendidikan hadapi dua isu besar (In year 2001, education will face two big issues). Kompas 8 December 2000. http//www.kompas.com/kompas-cetak/0012/8/dikbud/tahu09.htm [online accessed 31 March 2003]

Kompas, (2000f). Catatan Pendidikan akhir tahun (notes about education at year end). Kompas 23 December 2000 http//www.kompas.com/kompas-cetak/0012/23/dikbud/cata09.htm [online accessed 31 March 2003] 
Kompas, (2001a). Sekolah harus menjadi milik masyarakat (school should be owned by the community). Kompas 29 January 2001

http//www.kompas.com/kompas-cetak/0101/29/dikbud/seko09.htm [online accessed 01 April 2003]

Kompas, (2001a). Manajemen Berbasis Sekolah segera diujicobakan (school based management will soon be pilot projected). Kompas 14 February 2001. http//www.kompas.com/kompas-cetak/0102/14/dikbud/mana09.htm [online accessed 01 April 2003]

Kompas, (2004). Kerusakan bangunan SD, fenomena memalukan dan memilukan (The damage of school buildings is a shameful phenomenon). Kompas 14 February 2004. http://www.kompas.com/kompas-cetak/0402/14/humaniora/857258.htm [online accessed 23 April 2004]

Kompas, (2006a). Angka UN Harus naik (Final examination threshold mark should be increased). Kompas 5 May 2006. http://www.kompas.com/kompas-cetak/0605/05/humaniora/2631051.htm [online accessed: 5 May 2006]

Kompas, (2006b). Sarjanakan dulu guru (Made it all teachers have a bachelor degrees). Kompas 24 May 2006. http://www.kompas.com/kompas-cetak/0605/23/humaniora/2677713.htm [online accessed: 24 May 2006]

Kopong, E. (1995). Culture and Schooling: an explanatory study of curriculum localization in Indonesia. Unpublished PhD thesis, Flinders University of South Australia, Adelaide.

Krippendorff, K. (2004). Content Analysis, an introduction to its methodology. Thousand Oaks: Sage Publications.

Lauglo, J. (1995). Forms of Decentralisation and Their Implication for Education. Comparative Education, 31 (1) pp. 5-29.

Lee, K.H. (1995). Education and Politics in Indonesia 1945-1965. Kuala Lumpur, Malaysia: University of Malaya Press.

Leigh, B. (1999). Learning and Knowing Boundaries: Schooling in New Order Indonesia. SOJOURN: Journal of Social Issues in Southeast Asia 4 (1):24-56.

Leithwood, K. and Menzies, T. (1998). Forms and effects of school-based management: a review. Educational Policy. 12 (3) pp. 325-346.

Lindle, J. C. (1996). Lessons from Kentucky About School-Based Decision Making. Educational Leadership, December1995/January 1996, pp. 2023. 
Lombok Post. (2001). P3D belum diserahkan, Diknas Mataram protes Dikpora (Educational authorities has not been transferred, Mataram education district office complain to provincial education office). Lombok Post, 21 May 2001.

Madya, S. (2002). Educational Autonomy in Indonesia: at present and as designed for the future. Paper presented at Conference on Autonomy in Education in the Indonesian context, at The Australian National University, Canberra, 29 September 2002.

Malik, A. (2004). Dewan Pendidikan:Mission Impossible (Education Council: Mission Impossible). Sd-islam mailing list discussion http://groups.yahoo.com/group/sd-islam/message/5635 [online accessed 2 March 2004]

Malik, A. (2005). Ujian Nasional: Untuk Apa? (national examination: for what?). Kompas, 11 February 2005. http://www.kompas.com/kompascetak/0502/11/humaniora [online accessed 11-02-2005]

Marginson, S. (1993). Education and Public Policy in Australia. Cambridge: Cambridge University Press.

McGinn, N and Welsh, T. (1999). Decentralization of Education, why, when, what and how?. Fundamentals of Educational Planning - 64. Paris: UNESCO.

Available at: http://www.unesco.org/iiep

Miller, G. (1997). Contextualizing Texts: Studying Organizational Texts. In Context and Method in Qualitative Research, edited by G. Miller, Dingwall, R. Thousand Oaks, California: Sage.

Ministry of National Education (MoNE). (2001). Hasil Monitoring Program Manajemen Peningkatan Mutu Berbasis Sekolah (School Based Quality Improvement Management Monitoring Result). Jakarta: Direktorat SLTP dan Universitas Negeri Semarang.

Ministry of National Education (MoNE). (2002). Keputusan Menteri Pendidikan Nasional Republik Indonesia No. 044/U/2002 tentang Dewan Pendidikan dan Komite Sekolah (The decre of the Minister of National Education of the Republic of Indonesia number 044/U/2002 concerning Education Council and School Committee). Jakarta.

Mulyasa, E. (2002). Manajemen Berbasis Sekolah: konsep, strategi dan implementasi (school based management: concept, strategy and implementation). Bandung: Remaja Rosdakarya.

Murphy, J and Beck, L. G. (1995). School-Based Management as School Reform, Taking Stock. Thousand Oaks: Corwin Press. 
Nielsen, H.D. (2003). Reforms to Teacher Education in Indonesia: does more mean better? In Comparative Education Reader, edited by E. R. Beauchamp. New York: RoutledgeFalmer.

Nieuwenhuis, F. J. (2003). Managing Change During The Process of Decentralisation: A Question of Power and Authority. Paper presented at the International Conference on Education and Development, Oxford, UK.

Oplatka, I. (2004). The principalship in developing countries: context, characteristics and reality. Comparative Education. 40 (3): pp 427-448.

Patton, M. Q. (2002). Qualitative Research and Evaluation Methods (3rd ed.). Thousand Oaks: Sage.

Poerbakawatja, S. (1970). Pendidikan dalam Alam Indonesia Merdeka (Education in Independence Indonesia). Jakarta: Gunung Agung.

Purwono, E. (2003). SK Dewan Pendidikan (the decree about educational council). CFBE mailing list discussion http://groups.yahoo.com/group/cfbe/message/4409 [online accessed 24 August 2003]

Purwadi, A. and Muljoatmojo, H. (2000). Education in Indonesia: Coping with Challenges in the Third Millennium. Journal of Southeast Asian Education 1 (1): pp 79-102.

Rasyid, M.R. (2003). Arus balik ke pusat (a return flow to the centre). Tempo Magazine, 25 May 2003.

Rentoul, J and Rosanowski, J. (2000). The Effects of School Governance, ownership, organisation and management on educational outcomes. Strategic Research Initiative review 4, Christchurch College of Education. Wellington: Ministry of Education.

Ricklefs, M.C. (2001). A History of Modern Indonesia since c. 1200. 3rd ed. Hampshire: Palgrave.

Rideout, W.M. Jr. and Ural, I. (1993). Centralised and decentralised models of education: Comparative Studies. South Africa: Center for Policy Analysis, Development Bank of Southern Africa.

Rohdewohld, R. (2003). Decentralisation and the Indonesian bureaucracy: major changes, minor impact? In Aspinal, E. and Fealy, G. Local Power and Politics in Indonesia. Singapore: Institute of Southeast Asian Studies.

Rondinelli, D. A., Nellis, J. R and Cheema, G. S. (1983). Decentralization in Developing Countries, a review of recent experience. Washington D. C: The World Bank. 
Rose, P. (2003). Community Participation in School Policy and Practice in

Malawi: balancing local knowledge, national policies and international agency priorities. Compare 33 (1) pp. 47-64.

Rosyid, D.M. (2006). Ujian Nasional, Kematian Kreativitas (Final Examination, the dead of creativity). Kompas, 8 Mei 2006.

http://www.kompas.com/kompascetak/0605/08/humaniora/2633946.htm [online accessed 8-05-2006]

Sagala, S. (2003). Desain Organisasi Pendidikan dalam Implementasi Kebijakan Otonomi Daerah (Education Organisational Design for the Implementation Regional Autonomy Policy). Unpublished Doctorate thesis, Facultas Pasca Sarjana, Universitas Pendidikan Indonesia. Bandung.

Satori, D. (Ed). (2001). Pedoman Impementasi Manajemen Berbasis Sekolah di Jawa Barat (School based management implementation guide in West Java). Bandung: West Java Education Province Office.

Schwandt, T.A. (2000). Three Epistemological Stances for Qualitative Inquiry: Interpretivism, Hermeneutics and Social Construction. In Handbook of Qualitative Reseach, edited by Denzin and Lincolns. Thousand Oaks: Sage

Schiefelbein, E. and Schiefelbein, P. Three Decentralisation Strategies in two decades: Chile 1980-2000. Journal of Educational Administration 38 (5), pp. 412-425.

Sidi, I.D. (2001). Menuju Masyarakat Belajar, menggagas paradigma baru pendidikan (becoming learning community, ideas for new education). Jakarta: Paramadina.

Sihombing, P.B. (2004). Batalkan Konversi Nilai UAN (Abolish Final Examinationa Raw Score Conversion). Kompas, 15 Juni 2004. http://www.kompas.com/kompascetak/0406/15/opini/1082948.htm [online accessed 17-06-2004]

Smith, B.C. (2003). Understanding Third World Politics, theories of political change and development. 2nd ed. Indiana: Indiana University Press.

Soewartoyo (ed.). (2002). Desentralisasi Pendidikan dalam Perspektif Daerah, studi kasus di Kota Mataram (Educational decentralisation from regional perspective, case study in Mataram City). Jakarta: Pusat Penelitian Kependudukan- LIPI.

Soewartoyo (ed.). (2003). Persepsi Masyarakat terhadap Desentralisasi Pendidikan, studi kasus di Kota Manado (Society Perception about Educational decentralisation, case study in Manado City). Jakarta: Pustaka Sinar Harapan. 
Stake, R. E. (2000). Case Studies. In Handbook of Qualitative Reseach, edited by. Denzin and Lincoln. Thousand Oaks: Sage.

Subijanto. (2000). Pemantauan Pelaksanaan Program Bantuan Operasional Manajemen Mutu (BOMM) di SMUN 10 Surabaya (Studi Kasus) (A case study of monitoring of quality improvement operational assistance programme at State Secondary School Number 10 in Surabaya). Jurnal Dikbud Number. 027, November 2000.

Supriadi, D. (2002). Perubahan Pendidikan harus bertahap (education change should be staged). Pikiran Rakyat, 19 Desember 2002. http://www.pikiran-rakyat.com/cetak/1202/19/0107.htm [online accessed 4 April 2003]

Supriadi, D. (2003). Satuan Biaya Pendidikan Dasar dan Menengah (Educational costs of primary and secondary schooling). Bandung: Remaja Rosdakarya.

Surakhmad, W. (2002). Desentralizing education: a strategy for building sustainable capacity for regional development. Paper presented at Conference on Autonomy in Education in the Indonesian context, at The Australian National University, Canberra, 29 September 2002.

Suryadi, A. (1998). Manajemen Pendidikan Nasional Menuju Kemandirian Bangsa (managing national education to develop the nation). Kajian Dikbud, number 14, September 1998.

Suryadi, A. (2003). Dewan Pendidikan dan Komite Sekolah: mewujudkan sekolah-sekolah yang mandiri dan otonomi (Education Council and School Committee: creating autonomous schools). Seminar paper of the socialisation for empowering education council and school committee. http://www.depdiknas.go.id/serba_serbi/dpks/PemberdayaanDPKS.htm [online accessed 30 September 2004]

Taruna, J.C.T. (2001). "MBS Jalan Terus....Trus!" (SBM go ahead). Kompas, 1 May 2001 http://www.kompas.com/kommpas-cetak/0105/01/dikbud/mbs38.htm [online accessed 9 April 2003].

Taruna, J.C.T. (2003). "Sinyalemen Korupsi di Sektor Pendidikan" (Corrupt indication in educational sector). Kompas, 22 December 2003.

Thair, M and Treagust, D. F. (2003). A brief history of a science teacher professional development initiative in Indonesia and the implications for centralised teacher development. International Journal of Educational Development 23, pp. 201-213. 
Thomas, D., Beegle, K., Frankenberg, E., Sikoki, B., Strauss., J. and Teruel, G. (2004). Education in a crisis. Journal of Development Economics, 74, pp. 53-85.

Tilaar, H.A.R. (1992). Manajemen Pendidikan Nasional, kajian pendidikan masa depan (managing national education, a study of future education). Bandung: Remaja Rosdakarya.

Tilaar, H.A.R. (2000). Paradigma Baru Pendidikan Nasional (The new paradigm of National Education). Jakarta: Rineka Cipta.

Tim Pengembangan Dewan Pendidikan dan Komite Sekolah (Development Team of Education Council and School Committee). (2002). Panduan Umum Dewan Pendidikan dan Komite Sekolah (General Guideline of Education Council and School Committee). Directorate General of Primary and Secondary Education, Ministry of National Education. Jakarta

http://www.dikdasmen.depdiknas.go.id/html/dikdasmen/dewan\%20pendi dikan.htm

[online accessed 15 July 2003]

Umaedy. (1999). Manajemen Peningkatan Mutu Berbasis Sekolah (School-based quality improvement management). Jakarta: Ministry of Education and Culture.

Umar, J. (2004). Pendidikan nasional dalam ujian (examination in national education). Media Indonesia, 4 May 2004

http://www.mediaindo.co.id/newsprint.asp?Id=2004050401161628\&jenis =c\&cat_name $=$ Opini

[online accessed 5 June 2004]

Usman, S. (ed.). (2001). Dampak otonomi daerah terhadap layanan pendidikan (the implication of local autonomy to education service: a research report). Yogyakarta: Fisipol UGM.

van der Veur, Paul W. (1969). Education and Social Change in Colonial Indonesia (I), Papers in International Studies Southeast Asia Series No. 12. Athens, Ohio: Ohio University Center for International Studies, Southeast Asia Program.

White, C. (1997). Indonesian Social Studies Education: A Critical Analysis. The Social Studies 88 (2):87-91.

Whittey, G. and Power, S. (1997). Quasi-markets and Curriculum control: making sense of recent educational reforms in England and Wales. Educational Administration Quarterly, 33 (2), pp. 219-240.

Wirt, F., Mitchell, D.E. and Marshall, C. (1985). Perceptions of State Political Culture by Education Policy Elites. Peabody Journal of Education. 62 (4) pp. 48-60. 
Wohlstetter, P. and Odden, A. (1992). Rethinking School-Based Management Policy and Research. Educational Administration Quarterly. 28 (4) pp. 529-549.

World Bank. (2004). Education in Indonesia: Managing the Transition to Decentralisation. Volume 2. revised edition February 2004. Washington DC.

Wylie, C. (1995). Finessing site-based management with balancing acts. Educational Leadership. Vol. 53 No. 4 December 1995

Yin, R. K. (1994). Case Study Research, design and methods. 2nd ed. Thousand Oaks: Sage.

Yonezawa, A. and Muta, H. (2001). Financing Junior Secondary Education in Decentralised Administrative Structures: The Indonesian Example. Journal of International Cooperation in Education 4 (2):109-124. 


\section{Appendix 1}

\section{QUESTIONNAIRE}

\section{About School Based Management \\ for general secondary school stakeholders in Mataram}

TEACHERS`QUESTIONNAIRE

\section{Please use thick $\checkmark$ inside the box that suites to your condition.}

Example:

Are you a teacher?

$\checkmark$ Yes $\square$ No

\section{A. School Based Management}

1. Where do you get information on School Based Management (SBM) ? [you can answer more than one]

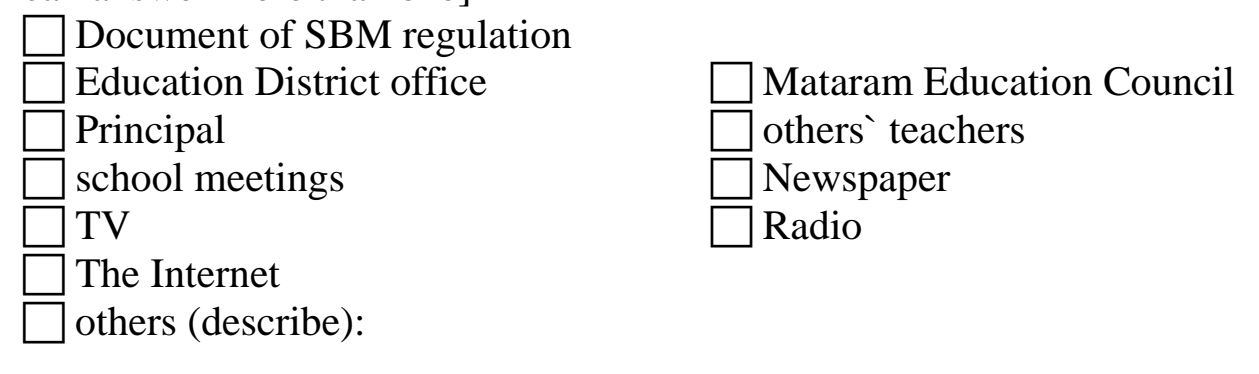

2. Do you think that you got enough information about the SBM policy?
$\square$ Yes
$\square$ Not sure
$\square$ No

3. Have you got special training of SBM?

$\square$ No $\square$ Yes

If you answer Yes, how long is the training that you attended ?

4. SBM policy wants to empower school stakeholders and deliver some authorities to school. What kinds of authorities do you think that can be given to school ? [you can answer more than one]

$\square$ school development plan
$\square$ staff management
$\square$ managing school facilities
$\square$ generating others resources
$\square$ others (describe):

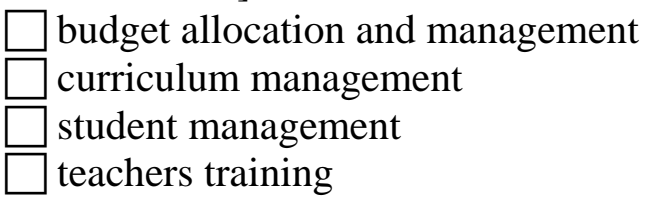


5. What is/are the school`s authority in terms of its financial management? [you can answer more than one]

$\square$ planning for school`s budget

$\square$ managing fund which is given by the government

$\square$ changing budget allocation

$\square$ managing teachers`salaries

$\square$ managing fund which is come from parents

I don`t know

$\square$ others (describe):

6. In your opinion, what is the school`s authority in terms of staff management?

[you can answer more than one]

$\square$ principal`s recruitment

$\square$ teachers 'recruitment

$\square$ administrative staff recruitment

$\square$ teachers performance evaluation

$\square$ teachers professional development

I don`t know

others (describe):

7. In terms of curriculum management, what kind of authority do you think that schools can exercise ? [you can answer more than one]
$\square$ teaching methods
$\square$ teaching materials
$\square$ curriculum development
textbooks choice
graduation examination
I don`t know
$\square$ others (describe):

8. How do you think the parents and the community participate in education ?

[you can answer more than one]

$\square$ managing funds which comes from parents

$\square$ maintaining school infrastructure (street, school yard etc.)

$\square$ participating in teaching and learning process

$\square$ undertaking extra-curricular activities

$\square$ coordinating out-school activities (recreation, tours etc.)

$\square$ supplying school facilities

$\square$ others (describe): 
9. Regarding the school committee, please thick the appropriate answer that applies to you.

\section{Yes No Don't know}

A. The school committee is an independent body which is not under school organisation

B. The school committee members are appointed by the principal

C. The school committee roles are different from BP3 (Badan pembantu

Penyelenggara Pendidikan = similar to Parents and teachers association)

D. The school committee has the right to control educational implementation in the school

E. The school committee approval is needed for the implementation of school budget plan and school development plan

10. To what extent would you agree with the view that SBM has been a good thing for your school?
$\square$ Agree
$\square$ Unsure
$\square$ Disagree

11. What do you see as the main benefits of SBM?

$\square$ Teacher feel part of more democratic decision-making
$\square$ School has control over own resources
$\square$ There is a feeling of ownership
$\square$ School able to develop environment to suit students
$\square$ Community and parents more involved in school
$\square$ others (describe):

12. What do you see as the main costs of SBM? [you can answer more than one]

$\square$ Time for, and quality of, teaching diminished

Extra duties incurred were not trained for

$\square$ Lack of resources and funds

$\square$ Teacher morale lowered

$\square$ others (describe): 
13. To what extent has your role changed as a result of the move to SBM?

$\square$ To a large extent

$\square$ To some extent

Not at all

14. Please rate the aspect of school based management that applies to you. Please thick the appropriate answer.
A. It has promoted more effective management of the school
Agree Unsure Disagree
B. It has improved decision making
C. Significantly increased community involvement in school decision-making
D. It has significantly improve school - community relations
E. It has promoted a more effective teaching
F. It has significantly improved the quality of student learning
G. It has promoted more freedom in deciding the methods of teaching and curriculum planning for teachers

\section{This is the end of the questionnaire. Thank you very much for your} cooperation.

If you have any general comments to add, please write down on this page. 


\section{B. Basic Information [Principals]}

1. What is your gender?

$\square$ female

male

2. Which is your age group?

\begin{tabular}{|l}
$\square 20-24$ \\
$\square \square 30-34$ \\
$\square 40-44$ \\
$\square 51-55$
\end{tabular}

$\square 25$ - 29
$\square 35-39$
$\square 45$ - 50
$\square$ more than 56 years

3. How long have you been a principal (years)?

$\begin{array}{ll}\square \text { less than } 2 \text { years } & \square 2 \text { - } 3 \\ \square 4-5 & \square 6-8\end{array}$

more than 8 years

4. How long have you been a principal in this school (years)?

$\begin{array}{ll}\square \text { less than } 2 \text { years } & \square 2-3 \\ \square 4-5 & \square 6-8 \\ \square \text { more than } 8 \text { years } & \end{array}$

5. What is your highest educational qualification?

\begin{tabular}{lll}
$\square$ Diploma II & $\square$ M.Ed \\
\hline$\square$ Diploma III & $\square$ Ph.D \\
\hline$\square$ undergraduate (B.Ed) &
\end{tabular}




\section{B. Basic Information [Teachers]}

1. What is your gender?

$\square$ female

male

2. Which is your age group?

$\square 20-24$
$\square 30-34$
$\square 40-44$
$\square 51-55$

$\square 25$ - 29
$\square 35-39$
$\square 45$ - 50
$\square$ more than 56 years

3. How many years have you been teaching?

$\begin{array}{ll}\square \text { less than } 2 \text { years } & \square 2-4 \\ \square 5-9 & \square 10-15 \\ \square 11-14 & \square 15-20\end{array}$

more than 20 years

4. Which subject matter are you teaching predominantly?

5. What is your highest educational qualification?

\begin{tabular}{lll}
$\square$ Diploma II & $\square$ M.Ed \\
\hline \begin{tabular}{ll} 
Diploma III \\
\hline
\end{tabular} & $\square$ Ph.D \\
& undergraduate (B.Ed) &
\end{tabular}

6. Which grades are you teaching at present?

11

2

7. Which of the following describes your present position in school?

$\square$ permanent teacher $\square$ non permanent teacher $\square$ Contract teacher 


\section{B. Basic Information [School Committee Members]}

1. What is your gender?

$\square$ female

male

2. Which is your age group?

$\square 20-24$
$\square 30-34$
$\square 40-44$
$\square 51-55$

$\square 25$ - 29
$\square 35-39$
$\square 45$ - 50
$\square$ more than 56 years

3. Have you been a member of the BP3?

$\square$ Yes

$\square$ No

If you answer yes, for how long?.......

4. How long have you been a member of the School Committee?

$\square$ less than 6 months

1 year $-1,5$ years

$\square 6$ months - 11 months more than 1,5 years

5. What is your highest educational qualification?

\begin{tabular}{ll}
$\square$ Diploma II & $\square$ M.Ed \\
\hline$\square$ Diploma III & $\square$ Ph.D \\
\hline$\square$ undergraduate (B.Ed) &
\end{tabular}

6. From which representative groups are you from?

$\square$ parents

$\square$ alumni

school staff

$\square$ non-governmental organisation others, please specify:....... 


\section{Appendix 2}

\section{Interview questions}

1. How important is the issue of school based management (for your school)? Please explain.

2. From your point of view, what kinds of authority have to be devolved to school in terms of school based management? Please explain.

3. School based management has been a central focus to administer school in the autonomy era, why do you think that the government chose this kind of policy?

4. What kinds of support from the district level has helped (to your school) to implement school based management?

5. What kind of relationship have you established between district-schoolcommunity in terms of school based management?

6. How do you think the parents and community will be involved, (particularly in your school)?

7. According to the Ministry of National Education decree (Kepmendiknas 044/U/2002) each school has to establish a school committee. Can you give me the process used to appoint the school committee in your school?

8. What is your opinion about the role that is given to the school committee based on the regulations? Do you think those roles will empower teachers, parents and community?

9. What are the current constraints to practicing school based management (in your school)?

10. What potential resources can improve the implementation of school based management (in your school)?

Notes: words in bracket aimed particularly to participants at school level (principals, teachers and school committee members) 


\section{Appendix 3}

\section{Appendix I of the MoNE decree Number 044/U/2002}

\section{A. Guidelines for Formation of Education Council}

I. Definition, Name and Scope

(1) Education Council is a body which provides a place for societal participation to increase quality, equity and efficiency of educational management in each district.

(2) Name of the organization is appropriated with local needs and condition such as Education Council, Education Assembly or others agreed names.

(3) Scope of educational levels are pre-school education, schooling system and out-of-school education.

II. Positions and Characteristic

(1) Position of Education Council is in a district.

(2) The characteristic of this body is autonomous, and doesn't have any hierarchical relationship with local government agency.

III. Aims

Aims of Education council are:

(1) Facilitating and channeling of societal aspiration and initiative in order to make policy and educational programs.

(2) Increasing responsibility and active participation from all layers of society in education implementation.

(3) Creating ambience and conditions for transparency, accountability, and democracy in quality education implementation and service.

IV. Roles and Functions

Roles of the Education Council are:

(1) As an advisory agency in deciding and implementing educational policy.

(2) As a supporting agency in terms of financial, thinking and labor in educational implementation.

(3) As a controlling agency in terms of transparency and accountability in educational implementation and outcomes.

(4) As a mediator between government (executive) and local parliament (legislative) with society. 
Functions of the Education Council are:

(1) Increasing society's attention and commitment to quality educational implementation.

(2) Conducting cooperation between society (individual/organization) with government and local parliament in terms of quality educational implementation.

(3) Receiving and analyzing aspirations, ideas, demands and educational needs that are proposed by society.

(4) Giving inputs, advice and recommends to local governments/local parliament about:

a) educational policy and programs;

b) local performance criteria in educational sector;

c) criteria for educational worker, in particular teacher/tutor and principal;

d) criteria for education facility; and

e) other things which are involved in education;

5) Motivating parents and society to participate in education for increasing quality and equity in education.

6) Conducting evaluation and supervision to educational policy, programs, implementation and outcome.

\section{Organization}

(1). Membership of Education Council

a. Education Council membership come from:

1) Elements of the society:

a). Non-Governmental Organization in Education;

b). Society prominent figure;

c). Education figure;

d). Foundation who manages educational institution (school, out of school, Islamic school, Islamic boarding school) ;

e). Business sector/industry/professional association;

f). Education professional organization;

g). School Committee

2). Elements of bureaucracy/legislative can be involved as members of Education Council (maximum 4-5 people)

b. Maximum members of Education Council are 17 (seventeen) people and total members should be an odd number. 
(2) Management of Education Council

a. At least has

1). Chairman

2). Secretary

3) Treasurer

b. Management chosen only by members.

c. Chairman position holder not to come from local government and parliament elements.

(5) Statutes and Rules of Organization

a. Education Council is required to have Statutes and Rules of Organization.

b. In the Statutes, at least have:

1). Name and location;

2). Foundation, aims and activities;

3). Membership and management;

4). Rights and Obligations of members and management;

5). Financial;

6). Work mechanism and meetings;

7). Changing of Statutes and Rules of Organization and organizational dispersal.

VI. Forming Education Council

(1). Forming principles

The principles to form Education Council have to apply:

a. transparent, accountable and democratic

b. as a partnership for local government

(2) Forming Mechanism

a. Forming of preparation committee

1). Head of district and/or society forms a preparation committee. The committee numbers are at least five people, consists of educational practitioner (such as teachers, principal, educational management) and educational observer (non-government organization in education, prominent figure, religious figure, business sector and industry).

2). Preparation committee's task is to prepare the formation of Education Council, which conducts:

a) Organize socialization forum to the public (which includes Education Assembly of local vocational education, District Committee, Out-of-Education Committee) about Education Council that are stated in this decree.

b) Creating a criteria and identified members' candidates based on public aspiration.

c) Selection of candidate members based on public aspiration.

d) Publish nominations of the members to the public.

e) Creating people's names who are selected;

f) Facilitating the choice of Education Council management and membership 
g) Giving Educational Council management and members to the head of district

b. Preparation committee is dissolved when head of district has stipulated Education Council

(3) Stipulating Education Council formation

Education Council stipulates for the first time with a decree from head of district, afterward it is regulated by Statutes and Rules of Organization.

VII. Inter-organization arrangement

The arrangement between Education Council with Local Government, Local Parliament, Education District Office and School Committees is coordinative.

VIII. Closing

(1) The formation of Education Council can be regulated by local legislation which have relationships with educational management in that district.

(2) The formation of Education Council can be facilitated by: Secretariat for Developing Education Council and School Committee, address Directorate General of Primary and Secondary Education, Gedung E $5^{\text {th }}$ floor, Jendral Sudirman street, Senayan, Jakarta, phone (021) 5725613, 5725608, fax (021) 5725608, website www.depdiknas.go.id, email dpkp2002@yahoo.com 
B. Example of relationship model between Education Council and other Institutions at district level (alternative 1).

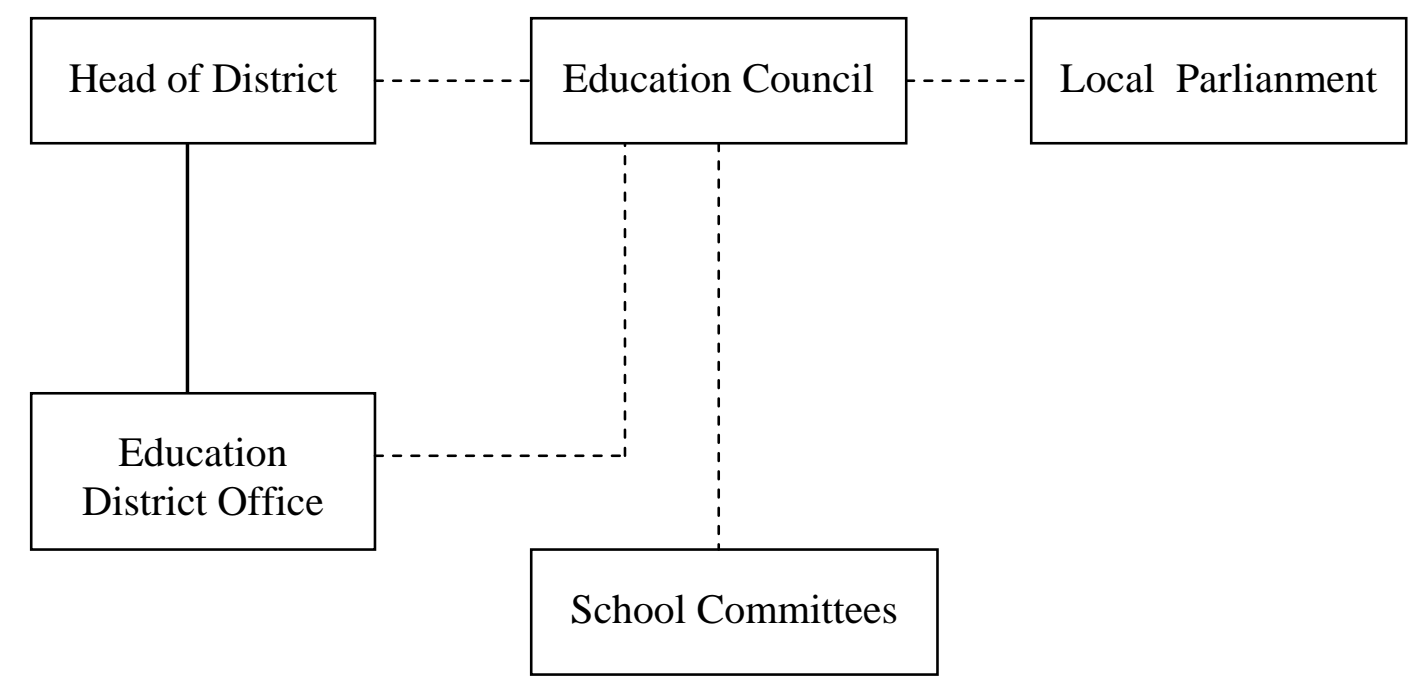

Legend: $\quad$ Instructive relationship

Coordinative relationship 
C. Example of relationship model between Education Council and other Institutions at district level (alternative 2).

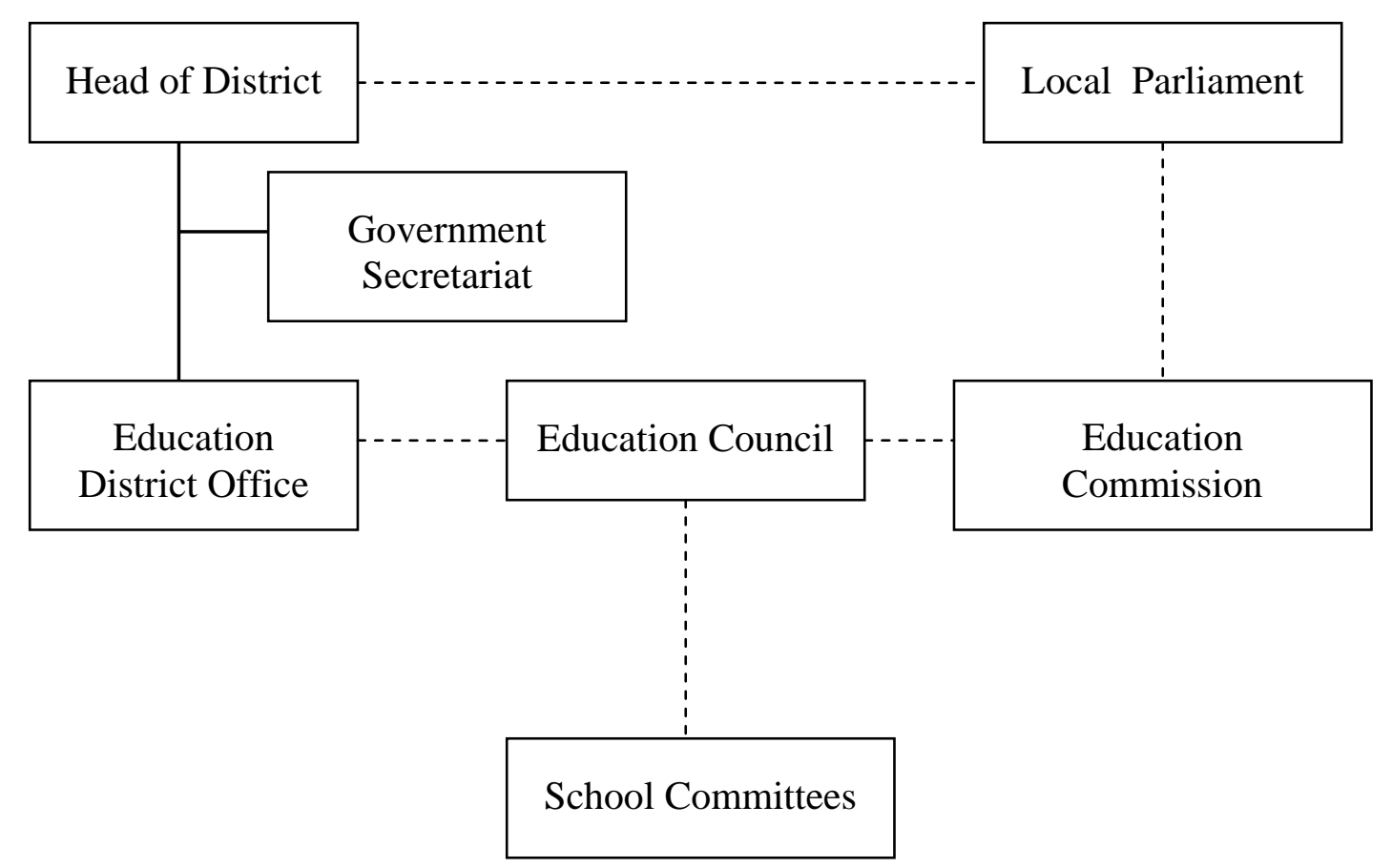

Legend: $\quad$ Instructive relationship

- - - - - coordinative relationship 
D. Example of organization structure for Education Council.

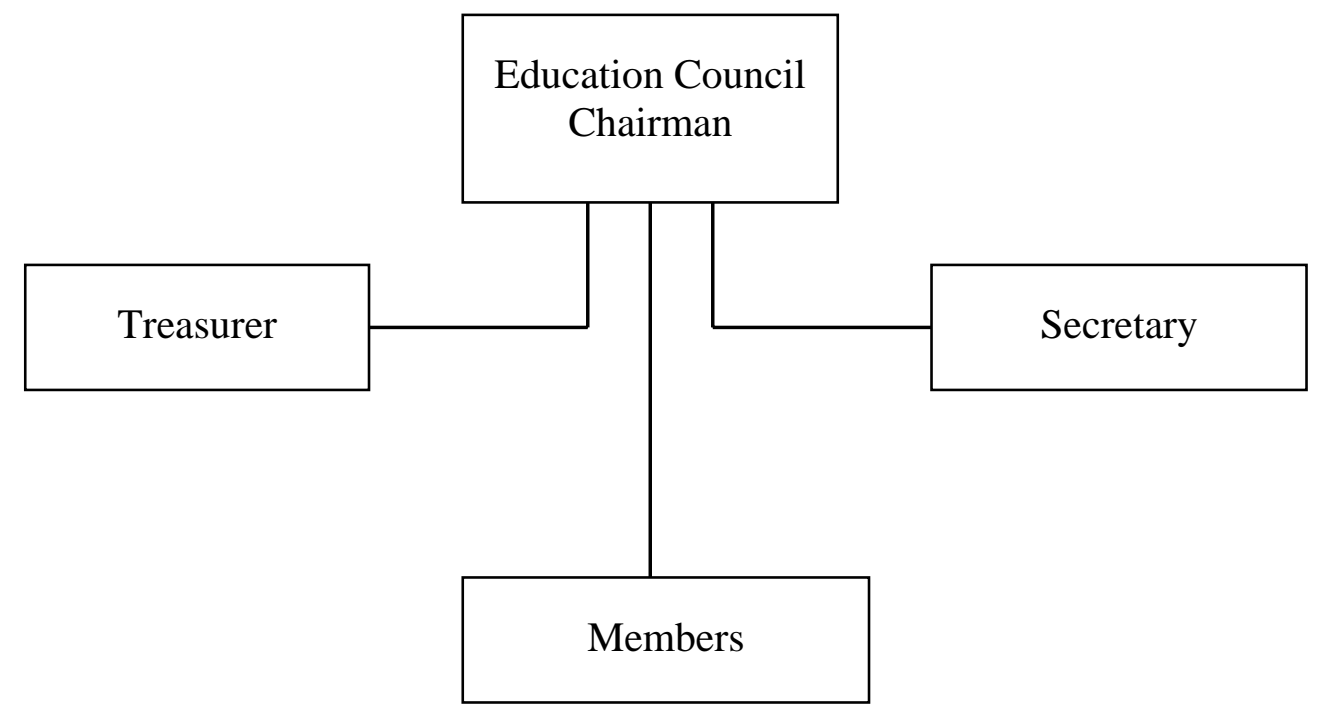

Legend:

Instructive relationship 


\section{Appendix II of the MoNE decree Number 044/U/2002}

\section{A. Guidelines for Formation of School Committee}

I. Definition and Name

(1) School Committee is an autonomous body which provides a place for societal participation to increase quality, equity and efficiency of educational management in each educational institution which are involved in pre-school education, schooling system or out-of-school education.

(2) Name of the organization is appropriated with local needs and condition of each educational institution such as School Committee, Education Committee, Out-of-School Education Committee, School Council, School Assembly, Madrasah Assembly, Kindergarten Committee or other agreed names.

(3) BP3, School Committee and/or School Assembly that are already established can widened it's function, roles and membership according to this guidelines.

II. Positions and Characteristic

(1) Position of School Committee is in an educational institution.

(2) School Committee can be established in one educational institution, or a number of institutions at the similar level, or in a number of institutions in various levels but which are within a relatively short distance, or educational institutions which are managed by the same organization, or because of other considerations

(3) The characteristics of this body is autonomous, and doesn't have any hierarchical relationship with government agency.

III. Aims

Aims of School Committee are:

(1) Facilitating and channeling societal aspirations and initiatives in order to make operational policy and educational program in one educational institution.

(2) Increasing responsibility and active participation of all layers of society in education implementation in educational institution.

(3) Creating ambience and condition for transparency, accountability, and democratic in quality education implementation and service in educational institution. 
IV. Roles and Functions

Roles of the School Committee are:

(1) As an advisory agency in deciding and implementing educational policy in educational institutions.

(2) As a supporting agency in terms of finance, thinking and labor in educational implementation in educational institutions.

(3) As a controlling agency in terms of transparency and accountability in educational implementation and outcomes in educational institution.

(4) As a mediator between government (executive) and society in educational institutions.

Functions of the School Committee are:

(1) Increasing society's attention and commitment to quality educational implementation.

(2) Conducting cooperation between society (individual/organization/business sector/industry sector) with government, in terms of quality educational implementation.

(3) Receiving and analyzing aspirations, ideas, demands and any other educational needs that are proposed by society.

(4) Giving inputs, advice and recommends to educational institution about:
a) educational policy and programs;
b) school budget plan;
c) performance criteria for educational institution;
d) criteria for education worker;
e) criteria for education facility; and
f) other things which involved in education;

5). Motivating parents and society to participate in education for increasing quality and equity in education.

6). Collecting money from the society to fund educational implementation in educational institution.

7). Conducting evaluation and supervision to educational policy, programs, implementation and outcome in educational institution.

\section{Organization}

(1). Membership of School Committee:

a. School Committee membership come from:

1) Elements of the society:

a). Parents;

b). Societal prominent figure; 

c). Education figure;
d). Business sector/industry.
e) education workers professional organization;
f). alumni representative;
g). student representative.

2). Elements of teacher council, foundations/management of educational institution, Rural Advisory Board can be involved as a member of Education Council (maximum 3 people)

b. Number of members of School Committee has a minimum of 9 (nine) people and the total members should be an odd number.

(2) Management of Education Council

a. At least has

1). Chairman

2). Secretary

3) Treasurer

b. Management chosen only by it's members.

c. Chairman's position is not be hold by head of educational institution.

(6) Statutes and Rules of Organization

a. School Committee is required to have Statutes and Rules of Organization.

b. In the Statutes at least have:

1). Name and location;

2). Foundation, aims and activities;

3). Membership and management;

4). Rights and Obligation of members and management;

5). Financial;

6). Work mechanism and meetings;

7). Changing of Statutes and Rules of Organization and organizational dispersal.

VI. Forming School Committee

(1). Forming principles

The principles to form a School Committee have to apply:

c. transparent, accountable and democratic

d. as a partnership of educational institution

(2) Forming Mechanism

a. Forming of preparation committee

1). Society and/or head of educational institution forms a preparation committee. The committee numbers are at least five people, consists of educational practitioner (such as teachers, principal, educational management) and educational observer (nongovernment organization in education, prominent figure, religious figure, business sector and industry) and parents. 
2). Preparation committee 's task is to prepare the formation of School Committee, conducts:

a). Organize socialization forum to the public (which includes members and management of BP3, School Assembly and School Committee that already existed) about School Committee that are stated in this decree.

b) Creating a criteria and identified members' candidates based on public aspiration.

c) Selection of candidate members based on public aspiration.

d) Publish nominations of the members to the public.

e) Creating people's names who are selected;

f) Facilitating the choice of School Committee management and membership

g) Giving School Committee management and members to the head of educational institution.

b. Preparation committee is dissolved when School Committee is established.

(3) Stipulating School Committee formation

School Committee stipulates for the first time with a decree from head of educational council, afterward it is regulated by Statutes and Rules of Organization.

VII. Inter-organization arrangement

The arrangement between School Committee with educational institution, Educational Council and others institution who has responsibility bin terms of educational management with School Committees in other educational institutions is coordinative.

\section{Closing}

(1) In the formation of School Committee, head of educational institution can be consulted with district government.

(2) The formation of School Committee can be regulated by local decree which have relationship with educational management in that district.

(3) The formation of School Committee can be facilitated by: Secretariat for Developing Education Council and School Committee, address Directorat General of Primary and Secondary Education, Gedung E $5^{\text {th }}$ floor, Jendral Sudirman street, Senayan, Jakarta, phone (021) 5725613, 5725608, fax (021) 5725608, website www.depdiknas.go.id, email dpkp2002@yahoo.com 
B. Example of relationship model between School Committee and other Institutions.

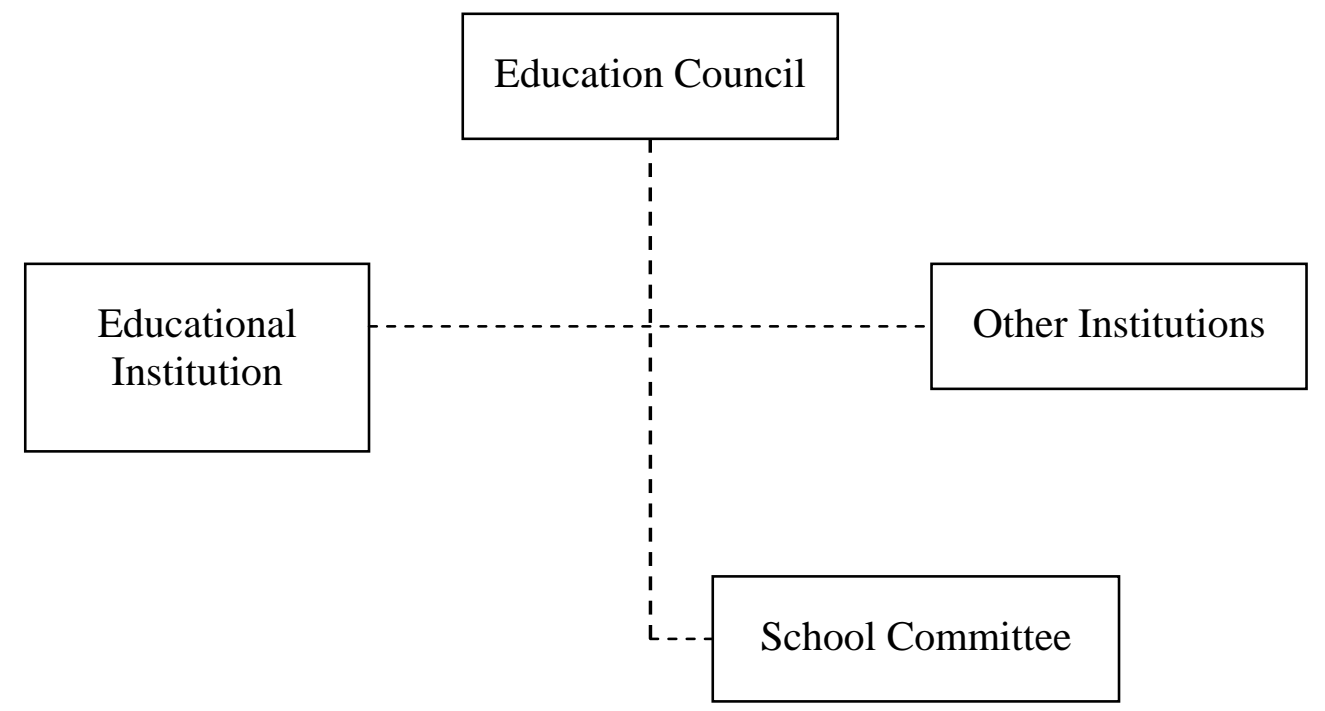

Legend: - ------- Coordinative relationship 
C. Example of Organization Structure of School Committee in one Educational Institution.

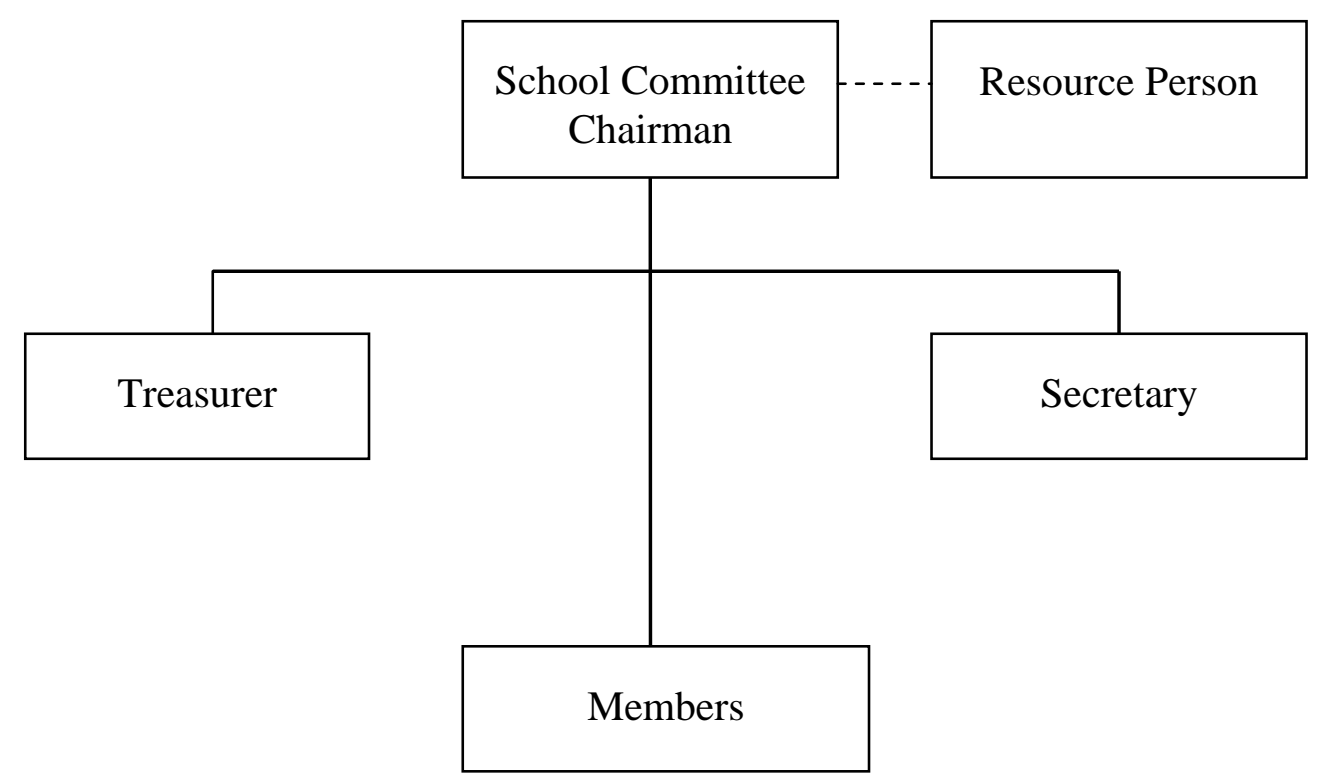

Legend: Instructive relationship

Coordinative relationship 
D. Example of Organisation Structure of One School Committee in several Educational Institutions.

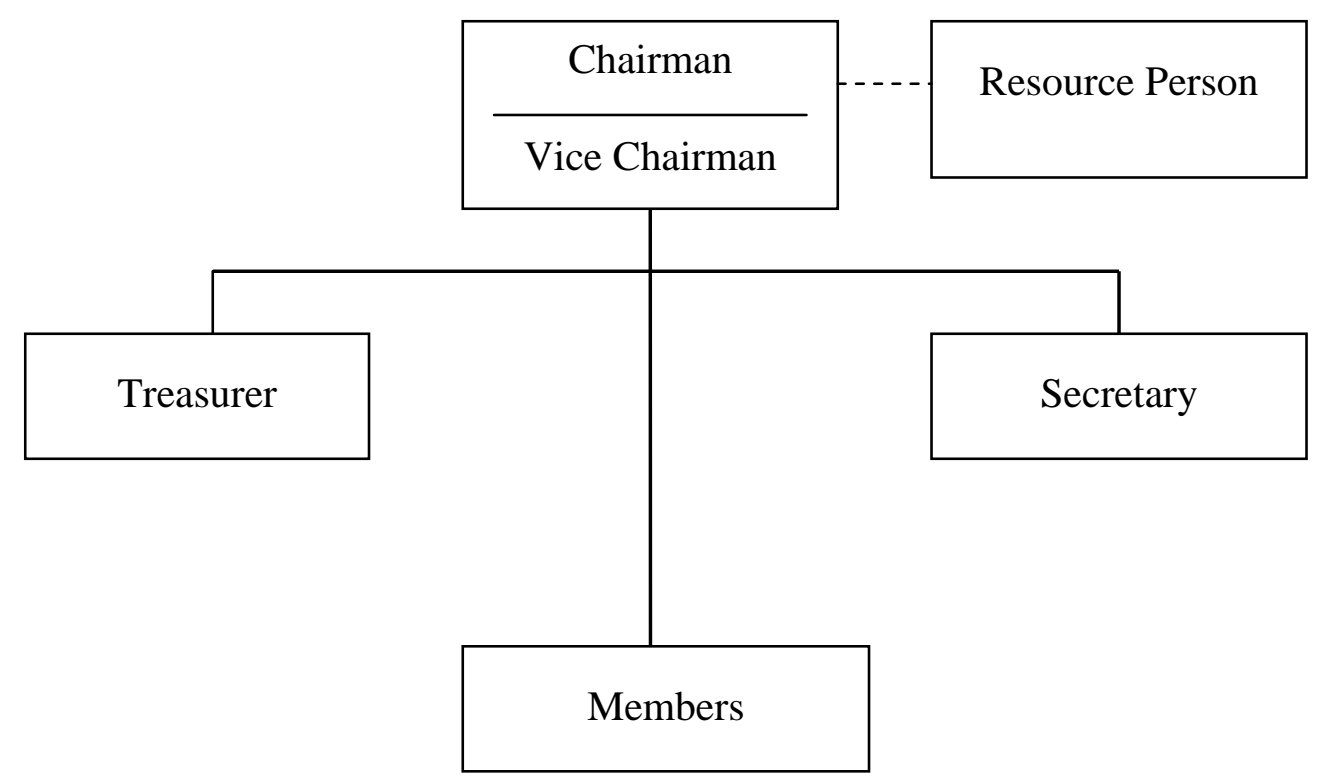

Legend: Instructive relationship

Coordinative relationship 


\section{Appendix 4}

Summary of Mataram District Budget year 2004.

Appendix I of Mataram District Regulation number 9/2004.

\begin{tabular}{|c|c|c|c|c|}
\hline No & Description & $\begin{array}{l}\text { Budget } \\
\text { before } \\
\text { adjustment }\end{array}$ & $\begin{array}{l}\text { Budget after } \\
\text { adjustment }\end{array}$ & $\begin{array}{l}\text { Amount } \\
\text { changes }\end{array}$ \\
\hline 1 & Incomes & & & \\
\hline 1.1 & Local tax & $17,104,583,150$ & $17,104,583,150$ & - \\
\hline 1.2 & $\begin{array}{l}\text { Subsidy from the } \\
\text { central } \\
\text { government }\end{array}$ & $191,584,706,315$ & $191,584,706,315$ & - \\
\hline \multirow[t]{2}{*}{1.3} & Other incomes & $9,434,596,978$ & $9,434,596,978$ & - \\
\hline & Total Incomes & $218,123,886,443$ & $218,123,886,443$ & - \\
\hline 2 & Expenses & & & \\
\hline 2.1 & Local personnel & $69,738,132,548$ & $72,085,975,040$ & $2,347,842,492$ \\
\hline 2.2 & Public services & 141,976,963,203 & $144,278,824,529$ & 2,301,861,326 \\
\hline 2.3 & Capital expenses & $10,317,114,800$ & $11,100,114,800$ & $783,000,000$ \\
\hline \multirow[t]{2}{*}{2.4} & Other expenses & $804,036,933$ & $853,445,055$ & $49,408,112$ \\
\hline & Total Expenses & $222,836,247,485$ & $228,318,359,425$ & $5,482,111,940$ \\
\hline & Surplus/(Deficit) & $(4,712,361,041)$ & $(10,194,472,981)$ & $(5,482,111,940)$ \\
\hline
\end{tabular}

Note: amount in Indonesia's rupiahs (1 US\$ equal to 10,000 rupiahs) 


\section{Appendix 5}

Mataram District Budget 2004 for Education and Culture Sector

(Note: amount in Indonesia's rupiahs; 10,000 rupiahs equal to US \$1)

\begin{tabular}{|c|l|r|r|l|}
\hline No & \multicolumn{1}{|c|}{ Description } & Project costs & \multicolumn{1}{c|}{ Targets } & \multicolumn{1}{c|}{ Purposes } \\
\hline 1 & $\begin{array}{l}\text { Building refurbishment and } \\
\text { classroom rehabilitation for junior } \\
\text { secondary schools }\end{array}$ & $23,790,000,000$ & Whole district & $\begin{array}{l}\text { To accommodate students } \\
\text { who finish primary } \\
\text { schooling }\end{array}$ \\
\hline 2 & $\begin{array}{l}\text { Erecting new senior secondary } \\
\text { schools }\end{array}$ & $6,800,000,000$ & $\begin{array}{c}\text { Three new state secondary } \\
\text { schools }\end{array}$ & $\begin{array}{l}\text { To accommodate students } \\
\text { who finish junior } \\
\text { secondary schooling }\end{array}$ \\
\hline 3 & Building new classrooms & $950,000,000$ & Seven new classroom & - \\
\hline 4 & Buildings refurbishment & $2,525,000,000$ & Thirteen schools & $\begin{array}{l}\text { Improving educational } \\
\text { activities }\end{array}$ \\
\hline 5 & Build school fence & $100,000,000$ & Two schools & - \\
\hline 6 & $\begin{array}{l}\text { Program for improving } \\
\text { educational services }\end{array}$ & $2,365,338,100$ & Whole district & $\begin{array}{l}\text { Improving capacity of } \\
\text { teachers, principals and } \\
\text { educational staff }\end{array}$ \\
\hline 7 & Supplying educational equipment & $2,111,250,000$ & Whole district & $\begin{array}{l}\text { Improving educational } \\
\text { quality }\end{array}$ \\
\hline
\end{tabular}




\begin{tabular}{|c|c|c|c|c|}
\hline No & Description & Project costs & Targets & Purposes \\
\hline 8 & $\begin{array}{l}\text { Support for final examination at } \\
\text { primary school level }\end{array}$ & $250,000,000$ & 200 schools & $\begin{array}{l}\text { To make final examination } \\
\text { running well }\end{array}$ \\
\hline 9 & Support for mid-term test & $750,000,000$ & 159 schools & $\begin{array}{l}\text { To make mid-term } \\
\text { examination running well }\end{array}$ \\
\hline 10 & Support for new student entrance & 80,000 & 32 schools & $\begin{array}{l}\text { To make new students } \\
\text { entrance process running } \\
\text { well }\end{array}$ \\
\hline 11 & $\begin{array}{l}\text { Support for primary school } \\
\text { teachers who pursue two years } \\
\text { university education }\end{array}$ & $150,000,000$ & 45 primary school teachers & $\begin{array}{l}\text { To improve teachers } \\
\text { educational qualification }\end{array}$ \\
\hline 12 & $\begin{array}{l}\text { Incentive for teachers who have } \\
\text { overload teaching hours }\end{array}$ & $250,000,000$ & $\begin{array}{l}65 \text { primary and junior } \\
\text { secondary teachers }\end{array}$ & $\begin{array}{l}\text { To pay primary and junior } \\
\text { secondary teachers who } \\
\text { have overload work }\end{array}$ \\
\hline 13 & $\begin{array}{l}\text { Support for printing and } \\
\text { distributing final examination of } \\
\text { primary and junior secondary level }\end{array}$ & $100,000,000$ & 200 schools & $\begin{array}{l}\text { To make final examination } \\
\text { have fund for printed } \\
\text { exam papers }\end{array}$ \\
\hline 14 & $\begin{array}{l}\text { Support for primary school and } \\
\text { junior secondary teachers who } \\
\text { pursue bachelor degree }\end{array}$ & $100,000,000$ & $\begin{array}{c}40 \text { primary or junior } \\
\text { secondary school teachers }\end{array}$ & $\begin{array}{l}\text { To improve teachers } \\
\text { educational qualification }\end{array}$ \\
\hline 15 & Training for school committee & $75,000,000$ & $\begin{array}{c}200 \text { school committee } \\
\text { members }\end{array}$ & $\begin{array}{l}\text { To improve school } \\
\text { committee members } \\
\text { quality }\end{array}$ \\
\hline
\end{tabular}




\begin{tabular}{|c|c|c|c|c|}
\hline No & Description & Project costs & Targets & Purposes \\
\hline 16 & $\begin{array}{l}\text { Support for kindergarten teachers } \\
\text { who pursue two years university } \\
\text { education }\end{array}$ & $100,000,000$ & 40 kindergarten teachers & $\begin{array}{l}\text { To improve teachers } \\
\text { educational qualification }\end{array}$ \\
\hline 17 & $\begin{array}{l}\text { Scholarship for secondary school } \\
\text { students }\end{array}$ & $110,160,000$ & $\begin{array}{l}306 \text { secondary school } \\
\text { students }\end{array}$ & $\begin{array}{l}\text { To motivate students who } \\
\text { do not have good } \\
\text { achievement }\end{array}$ \\
\hline 18 & $\begin{array}{l}\text { Scholarship for students who came } \\
\text { from poor economic background }\end{array}$ & $900,360,000$ & 2501 students & $\begin{array}{l}\text { To make the students not } \\
\text { drop out from schools }\end{array}$ \\
\hline 19 & $\begin{array}{l}\text { Incentive for non-permanent staff } \\
\text { at secondary school level }\end{array}$ & $240,000,000$ & 200 staff & $\begin{array}{l}\text { Improving non-permanent } \\
\text { staff income }\end{array}$ \\
\hline 20 & $\begin{array}{l}\text { Supporting students subsidy } \\
\text { program at sub-district offices }\end{array}$ & $15,000,000$ & 1 activity & $\begin{array}{l}\text { To support financially } \\
\text { sub-district offices in } \\
\text { students subsidy program }\end{array}$ \\
\hline 21 & $\begin{array}{l}\text { Incentive for teachers at private } \\
\text { schools }\end{array}$ & $720,000,000$ & $\begin{array}{l}600 \text { teachers at private } \\
\text { schools }\end{array}$ & $\begin{array}{l}\text { Improving private schools } \\
\text { teachers income }\end{array}$ \\
\hline 22 & Youth and student cultural activity & $300,000,000$ & 8 activities & $\begin{array}{l}\text { Improving creativity and } \\
\text { appreciation to art and } \\
\text { culture }\end{array}$ \\
\hline 23 & $\begin{array}{l}\text { Supporting art groups activity at } \\
\text { schools }\end{array}$ & $300,000,000$ & 40 art groups & $\begin{array}{l}\text { Funds for supporting art } \\
\text { activities at school }\end{array}$ \\
\hline
\end{tabular}




\begin{tabular}{|c|l|c|c|l|}
\hline No & \multicolumn{1}{|c|}{ Description } & Project costs & Targets & \multicolumn{1}{|c|}{ Purposes } \\
\hline 24 & Art training & $140,000,000$ & 40 people & $\begin{array}{l}\text { Funds for supporting art } \\
\text { activities }\end{array}$ \\
\hline 25 & $\begin{array}{l}\text { Competition for local song } \\
\text { composition }\end{array}$ & $20,000,000$ & $\begin{array}{l}\text { Improving creativity for } \\
\text { local song composition }\end{array}$ \\
\hline 26 & $\begin{array}{l}\text { Support for culture activities at } \\
\text { local, regional and national level }\end{array}$ & $30,000,000$ & 30 people & $\begin{array}{l}\text { Supporting people who } \\
\text { will attend local, regional } \\
\text { and national competition }\end{array}$ \\
\hline 27 & $\begin{array}{l}\text { Training for specific local art } \\
\text { kepembayunan) }\end{array}$ & $20,000,000$ & 80 people & $\begin{array}{l}\text { Improving and developing } \\
\text { specific local art } \\
\text { (kepembayunan) }\end{array}$ \\
\hline 28 & $\begin{array}{l}\text { Writing Competition about } \\
\text { traditional values }\end{array}$ & $30,000,000$ & $\begin{array}{l}\text { Improving traditional } \\
\text { values }\end{array}$ \\
\hline 29 & $\begin{array}{l}\text { Comparative study at other } \\
\text { historical unit in Indonesia }\end{array}$ & $40,000,000$ & 15 people & $\begin{array}{l}\text { Improving knowledge } \\
\text { about historical values }\end{array}$ \\
\hline 30 & $\begin{array}{l}\text { Supporting for historical } \\
\text { conservation and museum }\end{array}$ & $100,000,000$ & 5 groups & $\begin{array}{l}\text { Improving knowledge } \\
\text { concerning museum and } \\
\text { historical conservation }\end{array}$ \\
\hline 31 & $\begin{array}{l}\text { Traveling to other historical and } \\
\text { cultural sites in Indonesia }\end{array}$ & $\begin{array}{l}\text { Socialization of Law 5/1992 } \\
\text { concerning Museum and Historical } \\
\text { Artifacts }\end{array}$ & $50,000,000$ & $\begin{array}{l}\text { Improving culture } \\
\text { appreciation }\end{array}$ \\
\hline
\end{tabular}




\begin{tabular}{|c|c|c|c|c|}
\hline No & Description & Project costs & Targets & Purposes \\
\hline 33 & $\begin{array}{l}\text { Documenting historical oral } \\
\text { literature and culture }\end{array}$ & $50,000,000$ & 1 program & $\begin{array}{l}\text { Documentation for } \\
\text { historical and cultural data }\end{array}$ \\
\hline 34 & $\begin{array}{l}\text { Program for supporting secondary } \\
\text { level and out of school education: } \\
\text { 1. Selecting and developing youth } \\
\text { exchange program between } \\
\text { provinces. } \\
\text { 2. Scout activities for primary and } \\
\text { secondary school levels } \\
\text { 3. Race walking competition } \\
\text { 4. Sport equipment } \\
\text { 5. Program for improving literacy } \\
\text { 6. Training for flag raising } \\
\text { ceremony on independence day } \\
\text { and Mataram city day } \\
\text { 7. Sport and art competition at } \\
\text { primary school level }\end{array}$ & $\begin{array}{r}25,000,000 \\
25,000,000 \\
205,000,000 \\
294,000,000 \\
23,000,000 \\
75,000,000 \\
352,450,000\end{array}$ & $\begin{array}{l}1 \text { activity } \\
3 \text { activities } \\
3 \text { activities } \\
200 \text { people } \\
2 \text { activities }\end{array}$ & $\begin{array}{l}\text { Preparation for flag raising } \\
\text { ceremony on Indonesian } \\
\text { independence day }\end{array}$ \\
\hline
\end{tabular}




\section{Appendix 6}

School Budget year 2003/2004 from one state secondary school that participated in site studies.

(Note: amount in Indonesia's rupiahs; 10,000 rupiahs equal to US \$1)

\section{Income}

\begin{tabular}{|c|c|c|c|c|}
\hline No. & Year & $\begin{array}{c}\text { Number of } \\
\text { students }\end{array}$ & $\begin{array}{c}\text { Students who } \\
\text { are exempt to } \\
\text { pay fees }\end{array}$ & $\begin{array}{c}\text { Students who } \\
\text { required to pay } \\
\text { school fees }\end{array}$ \\
\hline 1 & 10 & 280 & 28 & 252 \\
\hline 2 & 11 & 240 & 24 & 216 \\
\hline 3 & 12 & 240 & 24 & 216 \\
\hline & Total & $\mathbf{7 6 0}$ & $\mathbf{7 6}$ & $\mathbf{6 8 4}$ \\
\hline
\end{tabular}

1. School fees, based on:
a. Head of education district office number: 422.4/632/B/Dik/2001

b. Mataram mayor circular letter number: 420/526/Kesra/2001

684 students x 12 months x 17,500

$143,640,000$

\section{Donation}

684 students x 12 months x 27,500

$225,720,000$

Total incomes

$369,360,000$

\section{Expense}

1. Subsidy for school staff

$152,874,000$

2. Supporting teaching and learning

$59,508,000$

3. Students activities

$29,754,000$

4. School Committee

$10,773,000$

5. Fees to coordination team

$3,591,000$

6. School Operational costs

$112,860,000$

Total expenses $\quad 369,360,000$ 


\section{Description}

\section{Subsidy for school staff}

1.1 Subsidy for Principal, Vice principals and head of administration staff

- Principal

$1 \times 12 \times 240,000 \quad 2,880,000$

- Vice principals

$4 \times 12 \times 100,000 \quad 4,800,000$

- Head of administration staff

$1 \times 12 \times 100,000 \quad 1,200,000$

1.2 Subsidy teachers who responsible for other activities

- Trainer of Students unions

$6 \times 12 \times 70,000$

$5,040,000$

- Trainer of extracurricular activities 14 x 12 x 70,000

$11,760,000$

- Home room teachers

$19 \times 12 \times 70,000$

$15,960,000$

- Coordinators

$5 \times 12 \times 70,000 \quad 4,200,000$

- Curriculum

$3 \times 12 \times 70,000$

$2,520,000$

- Infrastructure

$1 \times 12 \times 70,000$

840,000

- Public relations

$1 \times 12 \times 70,000$

840,000

- Teacher as duty officer

$6 \times 12 \times 60,000$

$4,320,000$

1.3 Incentive

- Based on teaching hours

$\begin{array}{rr}742 \times 12 \times 3,000 & 26,712,000 \\ 1 \times 12 \times 70,000 & 840,000 \\ 1 \times 12 \times 50,000 & 600,000 \\ 6 \times 12 \times 70,000 & 5,040,000\end{array}$

- Payroll officer

- Permanent Administration staff

$6 \times 12 \times 70,000$

$5,040,000$

1.4 Transportation

- Principal

- Vice Principals

$1 \times 12 \times 120,000$

$1,440,000$

- Head of administration staff

$4 \times 12 \times 70,000$

$3,360,000$

$1 \times 12 \times 70,000$

840,000

- Teachers

$51 \times 12 \times 60,000$

$6,720,000$

- Permanent Administration staff

$6 \times 12 \times 60,000$

$4,320,000$

- Home visit

392,000

- Transport for sport competition

$5,500,000$

1.5 Uniform for teachers and administration staff

$85 \times 150,000$

$12,750,000$ 


\section{Supporting teaching and learning}

2.1 Teaching and learning

- Mid-term examination

$2 \times 5,000,000$

$10,000,000$

- Preparation for final examination

$3,000,000$

- Written test

$4,000,000$

- Practice test

$3,000,000$

- Science laboratory experiment

$2,000,000$

- Language laboratory

$1,000,000$

- Enhancing for year 12 students' academic

$15,000,000$

- Psychology test for grade 11 students 240 x 15,000

$3,600,000$

- Relief teachers

$1,500,000$

- Teachers’ professional development

$5,000,000$

2.2 Teaching equipments

- Maintenance for curriculum materials

$3,000,000$

- Books for library and teachers’ library

$4,000,000$

- Classroom equipment

$2,000,000$

- Markers, erasers and ink for white boards

$2,408,000$

\section{Students activities}

- Student unions

- Training for flag raising ceremony group

$2,000,000$

500,000

- School health service (UKS)

- Scout

$1,454,000$

500,000

- Outdoor activities group

500,000

- English club

500,000

- Sports group

$1,000,000$

- Student research group

$4,000,000$

- Student religious groups

$4,000,000$

- School magazine

500,000

- Art and music

500,000

- School birthday

$3,000,000$

- Year 12 farewell ceremony

$1,800,000$

500,000

- New students entrance activity

$1,000,000$

- Religious day ceremony

$3,500,000$

- Mathematics and science Olympics in Mataram

$4,500,000$

\section{School Committee}

- School Committee meeting expenses

$2,733,000$

- School Committee annual meeting

$3,500,000$

- Fees for Principal association

$1,500,000$

- Students' cards

$760 \times 4000$

$3,040,000$

5. Fees to Coordination team

$3,591,000$ 


\section{School Operational costs}

- Fixed expenses

$12 \times 200,000$

$2,400,000$

- Electricity bill

$12 \times 300,000$

$3,600,000$

- Water bill

$12 \times 100,000$

$1,200,000$

- honorarium non-permanent teachers and extra hours for permanent teachers based on teaching hours

- Non-permanent administrative staff

$269 \times 12 \times 8,500$

$27,438,000$

$10 \times 12 \times 210,000$

$25,200,000$

$5 \times 12 \times 210,000$

$12,600,000$

- Gardener

$2 \times 12 \times 210,000$

$5,040,000$

- Night guards

$2 \times 12 \times 210,000$

- Transportation for non-permanent teachers

$8 \times 12 \times 50,000$

- Transportation for non-permanent administrative staff $5,040,000$

$4,800,000$

$19 \times 12 \times 50,000 \quad 11,400,000$

- Drinking water for teachers and staff

$3,400,000$

- Maintenance costs for building and garden

$2,642,000$

- Newspapers subscription

$1,500,000$

- Garbage collection fees

$12 \times 50,000$

600,000 
Appendix 7.1 Teachers' basic information $(n=57)$

\begin{tabular}{|c|c|c|c|c|c|c|c|}
\hline \multirow{2}{*}{$\begin{array}{l}\text { Q1 } \\
\text { Q2 }\end{array}$} & \multicolumn{2}{|c|}{$\begin{array}{l}\text { Gender: Male } \\
34(60 \%)\end{array}$} & \multicolumn{3}{|c|}{$\begin{array}{l}\text { Female } \\
23(40 \%)\end{array}$} & & \\
\hline & \multicolumn{7}{|l|}{ Age group } \\
\hline & $25-29 \quad 35-39$ & $40-44$ & $45-$ & & $51-55$ & $>55$ & Average \\
\hline & 15 & 24 & 1 & & 2 & 2 & 42 years \\
\hline \multirow[t]{3}{*}{ Q3 } & \multicolumn{7}{|c|}{ Total years teaching } \\
\hline & $<2 \quad 2-4$ & $5-9$ & $10-$ & & $15-20$ & $>20$ & Average \\
\hline & 1 & 1 & 2 & & 16 & 12 & 14.4 years \\
\hline \multirow[t]{3}{*}{ Q4 } & \multicolumn{7}{|c|}{ Teaching subject } \\
\hline & Maths Sciences & Soc. Scie. & Lang. & Sport & Art & Religion & Counseling \\
\hline & $6 \quad 13$ & 13 & 13 & 2 & 2 & 5 & 3 \\
\hline \multirow[t]{3}{*}{ Q5 } & \multicolumn{7}{|l|}{ Class taught $^{\mathbf{1}}$} \\
\hline & year $10(\mathrm{I})$ & year 11 (II) & & ar $12(\mathrm{I}$ & (III) & & \\
\hline & 28 & 28 & & & & & \\
\hline \multirow[t]{2}{*}{ Q6 } & \multicolumn{7}{|l|}{ Teacher positions } \\
\hline & \multicolumn{5}{|l|}{$\begin{array}{l}\text { Permanent teacher } \\
55\end{array}$} & \multicolumn{2}{|c|}{$\begin{array}{c}\text { contract teacher } \\
1\end{array}$} \\
\hline \multirow[t]{2}{*}{ Q7 } & \multicolumn{7}{|c|}{ Highest educational qualification } \\
\hline & \multicolumn{7}{|c|}{$\begin{array}{cc}3 \text { year diploma } & \text { Bachelor degree } \\
4 & 53\end{array}$} \\
\hline
\end{tabular}

Notes: ${ }^{1}$ many teachers taught more than one grade 
Appendix 7.2 School Committee Members' basic information (n=21)

\begin{tabular}{|c|c|c|c|c|c|c|}
\hline Q1 & Gender: & $\begin{array}{l}\text { Male } \\
18(86 \%)\end{array}$ & $\begin{array}{l}\text { Fema } \\
3(1\end{array}$ & Female & & \\
\hline \multirow[t]{3}{*}{ Q2 } & \multicolumn{6}{|c|}{ Age group } \\
\hline & $35-39$ & $40-44$ & $45-50$ & $51-55$ & $>55$ & Average \\
\hline & 1 & 4 & 7 & 3 & 6 & 47 years \\
\hline \multirow[t]{3}{*}{ Q3 } & \multicolumn{6}{|c|}{ Had been member of BP3 ${ }^{1}$} \\
\hline & \multicolumn{2}{|c|}{ Yes } & \multicolumn{4}{|l|}{ No } \\
\hline & \multicolumn{2}{|c|}{12 (57\%) } & $9(43 \%)$ & & & \\
\hline \multirow[t]{3}{*}{ Q4 } & \multicolumn{6}{|c|}{ Total time as committee members (months) } \\
\hline & $<6$ & 6-11 & $12-18$ & $>18$ & \multirow{2}{*}{\multicolumn{2}{|c|}{$\begin{array}{l}\text { Average } \\
12.5 \text { months }\end{array}$}} \\
\hline & 4 & 6 & 7 & 4 & & \\
\hline \multirow[t]{2}{*}{ Q5 } & \multicolumn{6}{|c|}{ Highest educational qualification } \\
\hline & \multicolumn{2}{|c|}{$\begin{array}{l}\text { Bachelor degree } \\
18(86 \%)\end{array}$} & \multicolumn{2}{|c|}{$\begin{array}{c}\text { Master degree } \\
3(14 \%)\end{array}$} & & \\
\hline \multirow[t]{3}{*}{ Q6 } & \multicolumn{6}{|c|}{ Which representative group represented } \\
\hline & Parents & Society & & chool staff & Othe & \\
\hline & 11 & 3 & & 4 & 3 & \\
\hline
\end{tabular}

Notes: ${ }^{1}$ previous organization before school committee, equal to parent-teacher organization ${ }^{2}$ local government officials and alumni 


\section{Appendix 7.3 Sources of SBM information}

\begin{tabular}{|c|c|c|}
\hline Q1 Information & ces about $\mathrm{SBM}^{1}$ & \\
\hline $\begin{array}{c}\text { Principals: } \\
\quad N=5\end{array}$ & $\begin{array}{l}\text { document of SBM regulation }{ }^{2} \\
\text { education district office } \\
\text { others (TV and internet) }\end{array}$ & $\begin{array}{l}5 \\
4 \\
1\end{array}$ \\
\hline $\begin{array}{c}\text { Teachers: } \\
N=57\end{array}$ & $\begin{array}{l}\text { principal } \\
\text { school meeting } \\
\text { education district office } \\
\text { other teachers } \\
\text { newspaper } \\
\text { document of SBM regulation }{ }^{2} \\
\text { others } \\
\text { (Education council, TV, Interne }\end{array}$ & $\begin{array}{c}47 \\
41 \\
21 \\
14 \\
10 \\
10 \\
7 \\
\text { adio) }\end{array}$ \\
\hline $\begin{array}{l}\text { School } \\
\text { Committee } \\
\qquad \mathrm{N}=21\end{array}$ & $\begin{array}{l}\text { principal } \\
\text { school meetings } \\
\text { document of SBM regulation }{ }^{2} \\
\text { education district office } \\
\text { others } \\
\text { (Education council, teachers, ne }\end{array}$ & $\begin{array}{l}16 \\
16 \\
9 \\
8 \\
8 \\
\text { paper, radio) }\end{array}$ \\
\hline
\end{tabular}

Notes: ${ }^{1}$ respondent can answer more than one choice

${ }^{2}$ The ministry of national education decree no 044/U/2002 


\section{Appendix 7.4 Authority devolved to school}

\begin{tabular}{|c|c|c|c|}
\hline \multirow[t]{4}{*}{ Q4 } & \multicolumn{3}{|c|}{ What kinds of authorities do you think that can be given to school? ${ }^{1}$} \\
\hline & $\begin{array}{l}\text { Principals: } \\
\quad \mathrm{N}=5\end{array}$ & $\begin{array}{l}\text { school development plan } \\
\text { managing school facilities } \\
\text { staff management } \\
\text { generating other resources } \\
\text { budget allocation and management } \\
\text { student management } \\
\text { teachers training } \\
\text { curriculum management }\end{array}$ & $\begin{array}{l}5 \\
5 \\
5 \\
5 \\
4 \\
4 \\
3 \\
2\end{array}$ \\
\hline & $\begin{array}{l}\text { Teachers: } \\
\text { N = } 57\end{array}$ & $\begin{array}{l}\text { managing school facilities } \\
\text { budget allocation and management } \\
\text { school development plan } \\
\text { student management } \\
\text { curriculum management } \\
\text { staff management } \\
\text { teachers training } \\
\text { generating other resources }\end{array}$ & $\begin{array}{l}44 \\
41 \\
38 \\
33 \\
29 \\
25 \\
25 \\
24\end{array}$ \\
\hline & $\begin{array}{l}\text { School } \\
\text { Committee } \\
\quad \mathrm{N}=21\end{array}$ & $\begin{array}{l}\text { school development plan } \\
\text { managing school facilities } \\
\text { budget allocation \& management } \\
\text { student management } \\
\text { generating other resources } \\
\text { teachers training } \\
\text { curriculum management } \\
\text { staff management }\end{array}$ & $\begin{array}{c}16 \\
14 \\
12 \\
10 \\
10 \\
10 \\
9 \\
8\end{array}$ \\
\hline
\end{tabular}

Notes: ${ }^{1}$ respondent can answer more than one choice 


\begin{tabular}{|lll|}
\hline Q5 & \multicolumn{2}{l}{ What kinds of authorities in terms of financial management do you think } \\
that can be given to the schools? & \\
Principals: & planning for school's budget & 5 \\
$\mathrm{~N}=5$ & managing fund from parents & 5 \\
& managing fund from government & 4 \\
& changing budget allocation & 2 \\
& managing teachers salary & 1 \\
& & 53 \\
Teachers: & planning for school's budget & 44 \\
$\mathrm{~N}=57$ & managing fund from parents & 37 \\
& managing fund from government & 17 \\
& changing budget allocation & 7 \\
& managing teachers salary & 1 \\
& I don't know & 21 \\
& & 20 \\
School & planning for school's budget & 14 \\
Committee & managing fund from parents & 10 \\
$\mathrm{~N}=21$ & managing fund from government & 2 \\
& changing budget allocation & \\
& managing teachers salary &
\end{tabular}

Notes: ${ }^{1}$ respondent can answer more than one choice 


\begin{tabular}{|c|c|c|c|}
\hline \multirow{2}{*}{\multicolumn{2}{|c|}{$\begin{array}{l}\text { Principals: } \\
\quad \mathrm{N}=5\end{array}$}} & $\begin{array}{l}\text { authorities in terms of staff manager } \\
\text { the schools? }\end{array}$ & lo you think that \\
\hline & & $\begin{array}{l}\text { administrative staff recruitment } \\
\text { teacher performance evaluation } \\
\text { teacher professional development } \\
\text { teacher recruitment } \\
\text { principal recruitment }\end{array}$ & $\begin{array}{l}5 \\
5 \\
3 \\
2 \\
1\end{array}$ \\
\hline & $\begin{array}{l}\text { Teachers: } \\
\qquad \mathrm{N}=57\end{array}$ & $\begin{array}{l}\text { teacher professional development } \\
\text { teacher performance evaluation } \\
\text { administrative staff recruitment } \\
\text { principal recruitment } \\
\text { teacher recruitment } \\
\text { I don't know }\end{array}$ & $\begin{array}{c}42 \\
41 \\
28 \\
18 \\
15 \\
5\end{array}$ \\
\hline & $\begin{array}{l}\text { School } \\
\text { Committee } \\
\qquad N=21\end{array}$ & $\begin{array}{l}\text { teacher performance evaluation } \\
\text { teacher professional development } \\
\text { administrative staff recruitment } \\
\text { teacher recruitment } \\
\text { principal recruitment } \\
\text { I don't know }\end{array}$ & $\begin{array}{c}16 \\
14 \\
8 \\
4 \\
1 \\
1\end{array}$ \\
\hline
\end{tabular}

Notes: ${ }^{1}$ respondent can answer more than one choice 
Appendix 7.7 Schools authority in terms of curriculum management

\begin{tabular}{|c|c|c|c|}
\hline \multirow[t]{4}{*}{ Q7 } & \multicolumn{3}{|c|}{$\begin{array}{l}\text { In terms of curriculum management, what kind of authority do you think } \\
\text { that schools can be exercised? }^{1}\end{array}$} \\
\hline & $\begin{array}{l}\text { Principals: } \\
\quad \mathrm{N}=5\end{array}$ & $\begin{array}{l}\text { teaching methods } \\
\text { curriculum development } \\
\text { textbook choice } \\
\text { teaching materials } \\
\text { graduation examination }\end{array}$ & $\begin{array}{l}4 \\
4 \\
4 \\
3 \\
2\end{array}$ \\
\hline & $\begin{array}{l}\text { Teachers: } \\
\quad \mathrm{N}=57\end{array}$ & $\begin{array}{l}\text { teaching methods } \\
\text { teaching materials } \\
\text { graduation examination } \\
\text { curriculum development } \\
\text { textbook choice }\end{array}$ & $\begin{array}{l}49 \\
44 \\
40 \\
37 \\
33\end{array}$ \\
\hline & $\begin{array}{l}\text { School } \\
\text { Committee } \\
\qquad N=21\end{array}$ & $\begin{array}{l}\text { teaching materials } \\
\text { curriculum development } \\
\text { teaching methods } \\
\text { textbook choice } \\
\text { graduation examination }\end{array}$ & $\begin{array}{c}14 \\
14 \\
11 \\
10 \\
9\end{array}$ \\
\hline
\end{tabular}

Notes: ${ }^{1}$ respondent can answer more than one choice 


\section{Appendix 7.8 Parents and community involvement in school}

\begin{tabular}{|cll|}
\hline Q8 & How do you think parents and community participate for school? ${ }^{1}$ \\
& & \\
Principals: & supplying school facilities & 5 \\
N=5 & managing fund comes from parents & 4 \\
& maintaining school facilities & 4 \\
& participating in teaching and learning & 3 \\
& undertaking extra-curricular activities & 1 \\
& coordinating out-of-school activities & 1 \\
& & \\
Teachers: & supplying school facilities & 50 \\
N =57 & maintaining school facilities & 33 \\
& participating in teaching and learning & 25 \\
& managing fund comes from parents & 21 \\
& coordinating out-of-school activities & 16 \\
& undertaking extra-curricular activities & 12 \\
& & \\
& supplying school facilities & 17 \\
School & maintaining school facilities & 15 \\
Committee & managing fund comes from parents & 11 \\
N=21 & coordinating out-of-school activities & 9 \\
& participating in teaching and learning & 9 \\
& undertaking extra-curricular activities & 7 \\
& \\
\hline
\end{tabular}

Notes: ${ }^{1}$ respondent can answer more than one choice 


\section{Appendix 7.9 Participants' view about School Committee}

Q9a School Committee is an independent body?

Principal

Yes

Teachers

No

3

School Committee 8

35

13

Don't know

2

21

Q9b School Committee members were decided by principal?

$\begin{array}{lccc} & \text { Yes } & \text { No } & \text { Don't know } \\ \text { Principal } & 1 & 4 & - \\ \text { Teachers } & 7 & 45 & 5 \\ \text { School Committee } & 2 & 18 & 1\end{array}$

Q9c School Committee roles is different from BP3?

$\begin{array}{lrrc} & \text { Yes } & \text { No } & \text { Don't know } \\ \text { Principal } & 4 & 1 & - \\ \text { Teachers } & 41 & 10 & 6 \\ \text { School Committee } & 17 & 4 & -\end{array}$

Q9d School Committee has right to control educational implementation?

$\begin{array}{lccc} & \text { Yes } & \text { No } & \text { Don't know } \\ \text { Principal } & 5 & - & - \\ \text { Teachers } & 56 & 1 & - \\ \text { School Committee } & 21 & - & -\end{array}$

Q9e School Committee approval is needed for school budget?

$\begin{array}{lccc} & \text { Yes } & \text { No } & \text { Don't know } \\ \text { Principal } & 5 & - & - \\ \text { Teachers } & 48 & 5 & 4 \\ \text { School Committee } & 21 & - & -\end{array}$




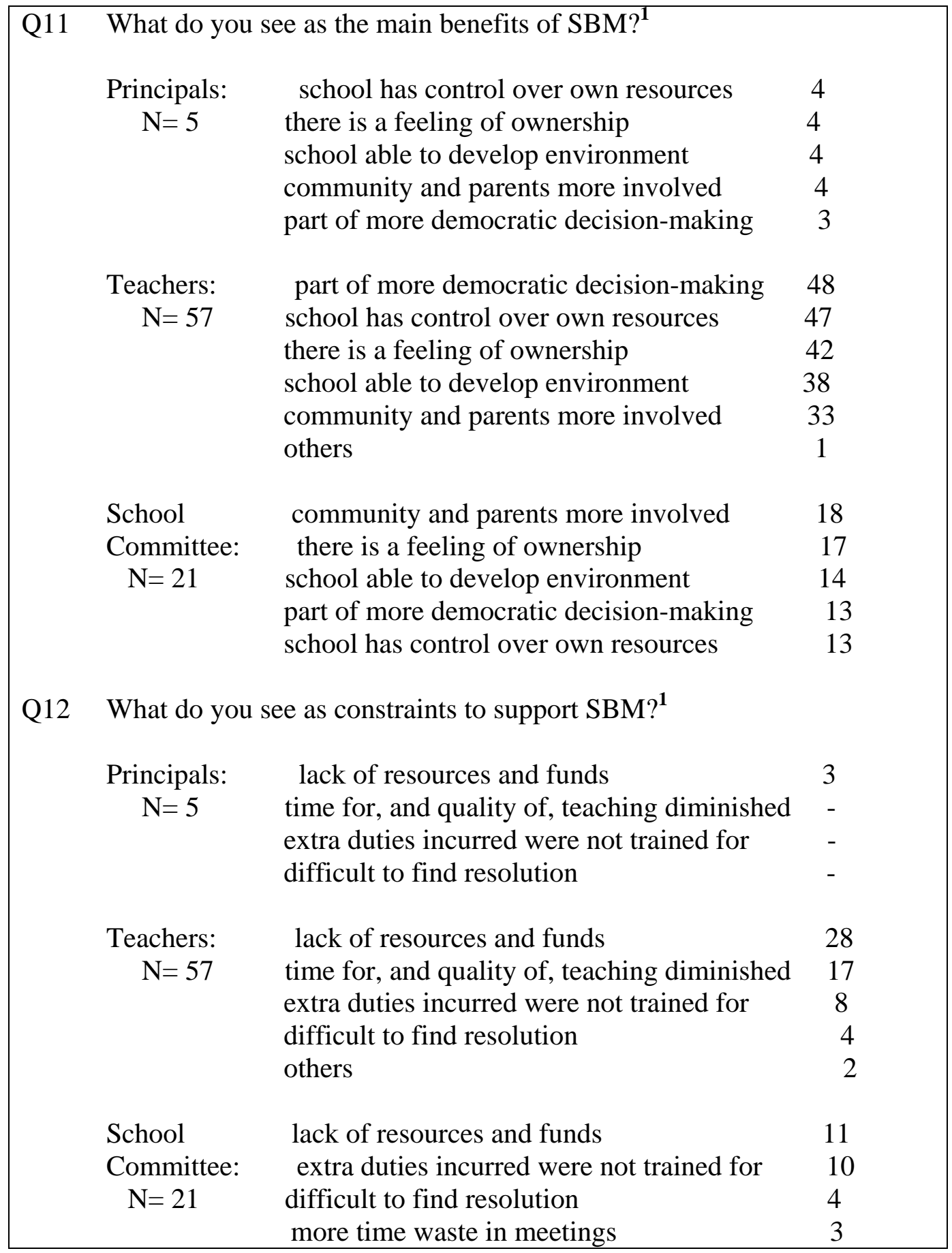

Notes: ${ }^{1}$ respondent can answer more than one choice 
Appendix 7.11 Participants' attitude toward SBM policy and practices

\begin{tabular}{|c|c|c|c|c|}
\hline \multirow[t]{5}{*}{ Q14a } & \multicolumn{4}{|c|}{ It has promoted more effective management of the school } \\
\hline & & Agree & Unsure & Disagree \\
\hline & Principal & 5 & - & - \\
\hline & Teachers & 49 & 8 & - \\
\hline & School Committee & 21 & - & - \\
\hline \multirow[t]{5}{*}{ Q14b } & \multicolumn{4}{|c|}{ It has improved decision making? } \\
\hline & & Agree & Unsure & Disagree \\
\hline & Principal & 5 & - & - \\
\hline & Teachers & 54 & 3 & - \\
\hline & School Committee & 20 & 1 & - \\
\hline \multirow[t]{5}{*}{ Q14c } & \multicolumn{4}{|c|}{$\begin{array}{l}\text { Significantly increased community involvement in school decision } \\
\text { making }\end{array}$} \\
\hline & & Agree & Unsure & Disagree \\
\hline & Principal & 4 & - & 1 \\
\hline & Teachers & 31 & 14 & 12 \\
\hline & School Committee & 16 & 3 & 2 \\
\hline \multirow[t]{5}{*}{ Q14d } & \multicolumn{4}{|c|}{ It has significantly improve school-community relations } \\
\hline & & Agree & Unsure & Disagree \\
\hline & Principal & 4 & 1 & - \\
\hline & Teachers & 48 & 9 & - \\
\hline & School Committee & 21 & - & - \\
\hline \multirow[t]{5}{*}{ Q14e } & \multicolumn{4}{|c|}{ It has promoted a more effective teaching } \\
\hline & & Agree & Unsure & Disagree \\
\hline & Principal & 4 & 1 & - \\
\hline & Teachers & 43 & 14 & - \\
\hline & School Committee & 18 & 3 & - \\
\hline \multirow[t]{5}{*}{ Q14f } & \multicolumn{4}{|c|}{ It has significantly improved the quality of student learning } \\
\hline & & Agree & Unsure & Disagree \\
\hline & Principal & 5 & - & - \\
\hline & Teachers & 37 & 20 & - \\
\hline & School Committee & 17 & 4 & - \\
\hline \multirow[t]{5}{*}{ Q14g } & \multicolumn{4}{|c|}{$\begin{array}{l}\text { It has promoted more freedom in deciding the methods of teaching } \\
\text { and curriculum planning for teachers }\end{array}$} \\
\hline & & Agree & Unsure & Disagree \\
\hline & Principal & 3 & - & 2 \\
\hline & Teachers & 38 & 14 & 5 \\
\hline & School Committee & 11 & 6 & 4 \\
\hline
\end{tabular}

